\title{
Mobility, Voice and View: \\ Unpacking the Future of Cape Town's District Six
}

\author{
by Gabrielle Argent \\ A thesis submitted to the Faculty of Graduate and Postdoctoral Affairs \\ in partial fulfillment of the requirements for the degree of
}

Master of Architecture
Azrieli School of Architecture and Urbanism
Carleton University
Ottawa, Ontario

(c) 2020

Gabrielle Argent 
This thesis contains supplemental video content.

Please follow the links provided to enrich the story experience.

Thank you. 


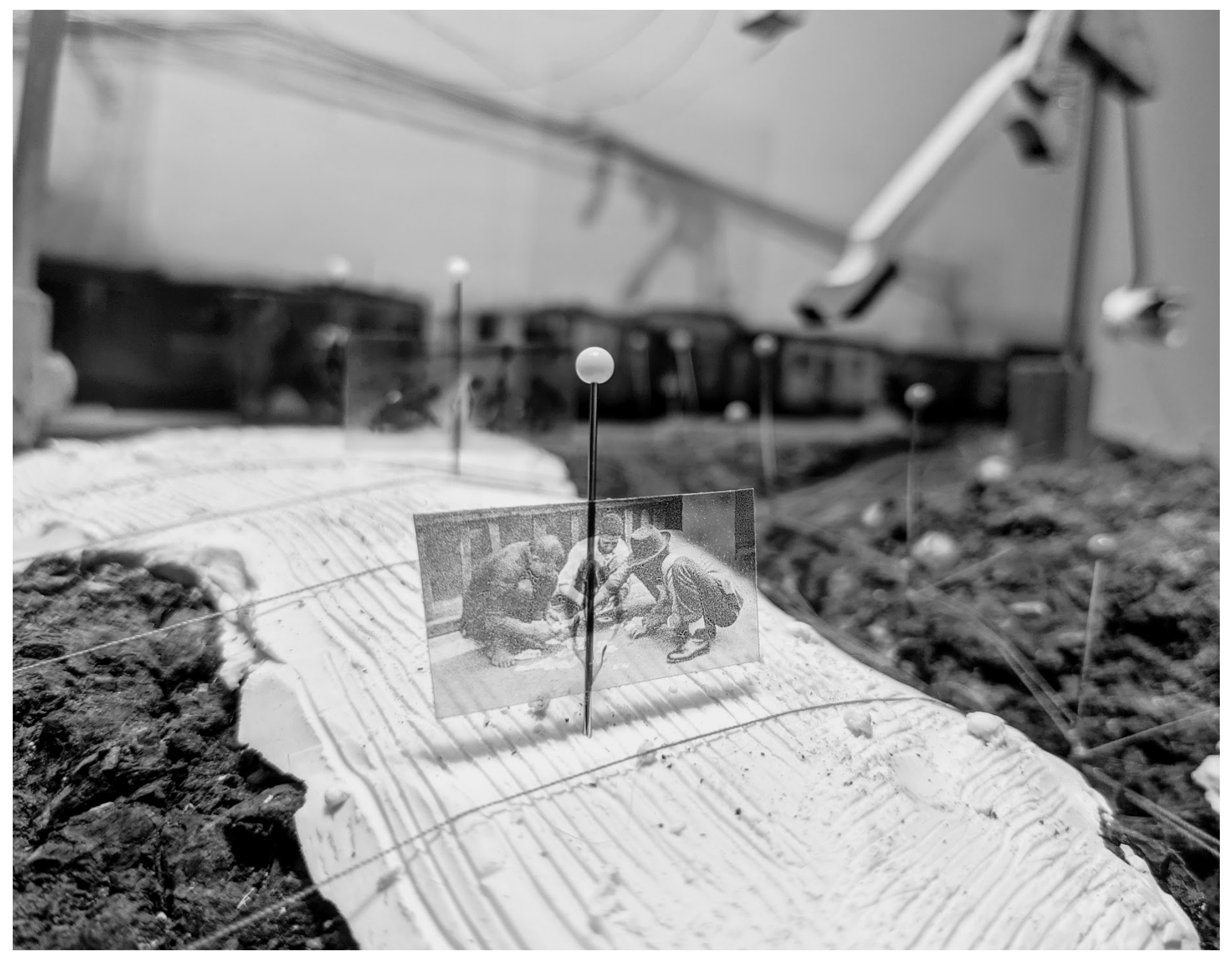

Fig. 1 Model of an activated site in Langa Township. 


\section{Abstract}

Cape Town's District Six stands as a site representative of the physical and social erasure and racial division seen in the spatial politics of apartheid South Africa. From 1966-1978, residents were forcibly removed from the area. Then and now, infrastructures have marginalized and isolated these past residents from the city.

In response to this complex history, this project explores the role of agency in architecture. This thesis argues that architecture when conceived through the agencies of mobility, voice and view, can empower people to regain control of their physical, cultural and socio-political identities.

Exploring these agencies, this project endeavours to make visible and empower the residents by re-conceptualizing the infrastructure of the train under the following lens: the train line as a spatial connector and claim to the city (mobility); train stations as township cultural centers (voice); and the train car as a mobile vessel for public programming (view). 


\section{Acknowledgements}

This has been an extraordinary year to complete a thesis project with the onset of the COVID-19 pandemic. There have been many hardships and challenges along the way, but I could not have been more proud of the work I have completed, and I would not have been able to accomplish all my goals without the support, help and guidance of a number of important people.

I want to give a sincere thank you to my thesis advisors Jerry Hacker and Jill Stoner for your expert guidance, support and creativity. It has been inspiring to work with you both this year, and I will be a better architect and person for it.

Thank you as well to the many other professors and staff at the school. I am lucky to have had the privilege to learn from you all. I also want to say thank you to the Azrieli School of Architecture and Urbanism for giving me the opportunity to travel to South Africa in 2019.

A special thank you to the many friends I made in the program, especially David Woodruff and Maya Jarrah who provided a lot of much needed support and many laughs throughout the past year.

Thank you to Dael for your unfailing love and loyalty. Your hole-hearted belief in me has helped me to better believe in myself.

Lastly, thank you to my family, especially my parents who always told me I could do anything. Your love and support throughout my entire education has been the reason I have been able to accomplish all my dreams. 


\section{Table of Contents}

$\begin{array}{lll}\text { IV } & \text { Abstract } \\ \text { V } & \text { Acknowledgements } \\ \text { VI } & \text { Table of Contents } \\ \text { VII } & \text { List of Illustrations } \\ \mathbf{1} & \text { Introduction } & \\ \mathbf{8} & \text { Chapter One: } & \text { The Story of Cape Town's District Six } \\ \mathbf{1 8} & \text { Chapter Two: } & \text { The Erasure of District Six } \\ \mathbf{2 9} & \text { Chapter Three: } & \text { The Erasure of Agency } \\ \mathbf{4 5} & \text { Chapter Four: } & \text { Restoring Agency By Design } \\ \mathbf{8 1} & \text { Chapter Five: } & \text { A New Fabric for District Six } \\ \mathbf{9 0} & \text { Chapter Six: } & \text { Epilogue: A Personal Story } \\ \mathbf{9 5} & \text { Chapter Seven: } & \text { Afterword: 'A Story From Away' } \\ -99 & \text { Notes } & \\ \mathbf{1 0 4} & \text { Bibliography } & \\ & & \end{array}$




\section{List of Illustrations}

Fig. 1 Model of an activated site in Langa Township.

Fig. 2 Man sleeping on the grass in the Company's Garden during my trip to Cape Town in February 2019.

Fig. 3 Time Magazine cover of an 'unequal' South African landscape.

https://time.com/5581483/time-cover-south-africa/

Fig. 4 District Six, now called 'Zonnebloem', is represented by the yellow pin. A fundamental space in the Cape Town city center.

Fig. 5 District Six and its connected townships of Langa, Guguletu, Manenberg, Bonteheuwel, Heideveld, Hanover Park and Mitchells Plain depicted with yellow pins.

Fig. 6 Achmat Dangor, (1983) 'Paradise,' in Bulldozer, Johannesburg: Raven Press, 3.

Fig. 7 Video Still, District Six prior to the forced removals and site erasure. Please watch:

https://www.youtube.com/watch?v=n2gcqRX9RDs

Fig. 8 Photographs depicting daily life and the conditons of District Six prior to the forced removals, taken by the South-African photographer Jansje Wissema.

https://digitalcollections.lib.uct.ac.za/jansje-wissema
Fig. 9 Excerpt from Richard Rive, Buckingham Palace District Six, 1986, 72-80.

Fig. 10 Jennifer Davids, 'Location Fires' in Chapman, Michael and Dangor, Achmate (eds) (1982) Voices from Within: Black Poetry from South Africa, Johannesburg: Ad. Donker, 97.

Fig. 11 A map of Langa Township layout from 1923. in Nicholas Coetzer, Building Apartheid: On Architecture and Order in Imperial Cape Town. Surrey: Ashgate, 2013, 195.

Fig. 12 Excerpt from Richard Rive, Buckingham Palace District Six, 1986, 72-80.

Fig. 13 Video Still, the beginning of the erasure of District Six.

Fig. 14 Jansje Wissema photos with an erased element and stitched outline.

Fig. 15 Video Still, the continued erasure of District Six.

Fig. 16 Outlines of demolished spaces in District Six. https://unequalscenes.com/district-six

Fig. 17 Video Still, District Six erased.

Fig. 18 Excerpt from Richard Rive, Buckingham Palace District Six, 1986, 72-80. 
Fig. 19 Excerpt from Richard Rive, Buckingham Palace District Six, 1986, 72-80.

Fig. 20 Video Still, District Six in present day.

Fig. 21 Conceptual representation of the erasure of 'mobility.'

Fig. 22 Langa Township infrastructure map, green (highways), yellow (railway), dark blue (electrical corridor), light blue (water), black line (land buffer), dark red (public space).

Fig. 23 Stitching with orange thread the existing train infrastructure of Bonteheuwel Township.

Fig. 24 Conceptual representation of the erasure of 'voice.'

Fig. 25 Stitching with black thread the existing land buffers of Mitchells Plain Township.

Fig. 26 Conceptual representation of the erasure of 'view.'

Fig. 27 The erased and stitched photos posit conditions that were lost during the forced removals and erasure of the site.
Fig. 28 Original District Six site model depicting barren areas in grey clay, demolished and built on areas (yellow) and untouched areas (red).

Fig. 29 Compiled voices of the former residents of Distict Six.

Fig. 30 Video Still, restoring agency on the original site of District Six. Please watch:

https://www.youtube.com/watch?v=lBkt8 9r Io

Fig. 31 Inside the District Six Museum.

https://www.districtsix.co.za/

Fig. 32 William Kentridge, Felix in Exile, 1994 https://www.moma.org/audio/playlist/1/248

Fig. 33 Experiments with palimpsest and acupuncture in the landscape of Langa Township.

Fig. 34 Mongane Wally Serote, (1974), 'Death Survey,' in Tsetlo, Johannesburg: Ad, Donker, 48.

Fig. 35 Conceptual physical model depicting the train line through the use of wood, gel wax, printed acetate, clay, sewing pins and thread.

Fig. 36 Threads are stitched to represent the activated spaces and connecting pathways around the needles. The activated zones affect and contradict the existing logic of the urban environment. 
Fig. 37 The train line as depicted by threads and acupuncture points in the landscape.

Fig. 38 Video Still, the train moves across the urban environment affecting the spaces below. Please watch: https://www.youtube.com/watch?v=yEfqDlOtRmg\&t=4S

Fig. 39 Video Still, threads pass through acupuncture points, digitally transferring messages through the landscape.

Fig. 40 Video Still, the train arrives at the train station, bringing data to upload to the fabric.

Fig. 41 Jennifer Davids, 'Location Fires' in Chapman, Michael and Dangor, Achmate (eds) (1982) Voices from Within: Black Poetry from South Africa, Johannesburg: Ad. Donker, 97.

Fig. 42 Past residents of District Six play games in the activated zones of the townships.

Fig. 43 Physical model depicting the residents in one of the activated sites.

Fig. 44 Children play below the acupuncture needles.

Fig. 45 Video Still, needles collect water for the community on the activated site as it rains. Please watch: https://www.youtube.com/watch?v=0OIxAQfOMrE
Fig. 46 Water drains from the dense threads into a basin as the needle head moves upwards.

Fig. 47 Growing food under the fabric canopy on one of the activated sites in Langa Township.

Fig. 48 Residents of Langa Township play games and music on one of the activated sites.

Fig. 49 Excerpt from Richard Rive, Buckingham Palace District Six, 1986, 72-80

Fig. 50 Conceptual collage for the train. Parts of the train are deconstructed to imagine the possibility of new potential uses.

Fig. 51 Early model, strings move through the different time periods of District Six, visualizing what was erased from the site.

Fig. 52 Over time the site was erased, leaving few remnants of the past urban environment.

Fig. 53 The train car, conceputally represented through the past, present and imagined future. Please watch: https://www.youtube.com/watch?v=7JlRay2Cggs

Fig. 54 Threads and shadows show the erasure of elements of view over time. 
Fig. 55 Passengers ride the train and look outside to the constantly transforming landscape.

Fig. 56 Shadows cast conceptually represent the passengers imprinting themselves on the landscape and creating a new future.

Fig. 57 Excerpt from 'My District Six Pigeons,' in Ciraj Rassool and Sandra Prosalendis, Recalling Community in Cape Town: Creating and Curating the District Six Museum. Cape Town: District Six Museum, 2001, 57.

Fig. $\mathbf{5 8}$ Video Still, the new fabric over the original site of District Six.

Fig. 59 The clay site model with the new District Six fabric.

Fig. 60 The new fabric depicts a form which is a representation of the past, present and future.

Fig. 61 Threads connect the above and below spaces of the urban fabric.

Fig. 62 Activated spaces are a reflection of the old fabric and the new.

Fig. 63 Imagined fabric with excerpt from Richard Rive, Buckingham Palace District Six, 1986, 72-80.
Fig. 64 Notes taken from a lecture with Tony Elvin while visiting Ikhaya Le Langa in 2019.

Fig. 65 Langa Township. Photo courtesy of Laurence Massicotte.

Fig. 66 Langa Township. Photo courtesy of David Woodruff.

Fig. 67 Razor fence where children play in Langa Township. Personal photo.

Fig. 68 Community art in Langa Township. Personal photo.

Fig. 69 Cape Town studio group posing with the finished pergola at Ikhaya Le Langa in Langa Township. Courtesy of Nic Coetzer.

Fig. 70 Creating the 'story from away.'

Fig. 71 Comparing hands with some of the first San humans in South Africa. Stories are shared across space and time. 


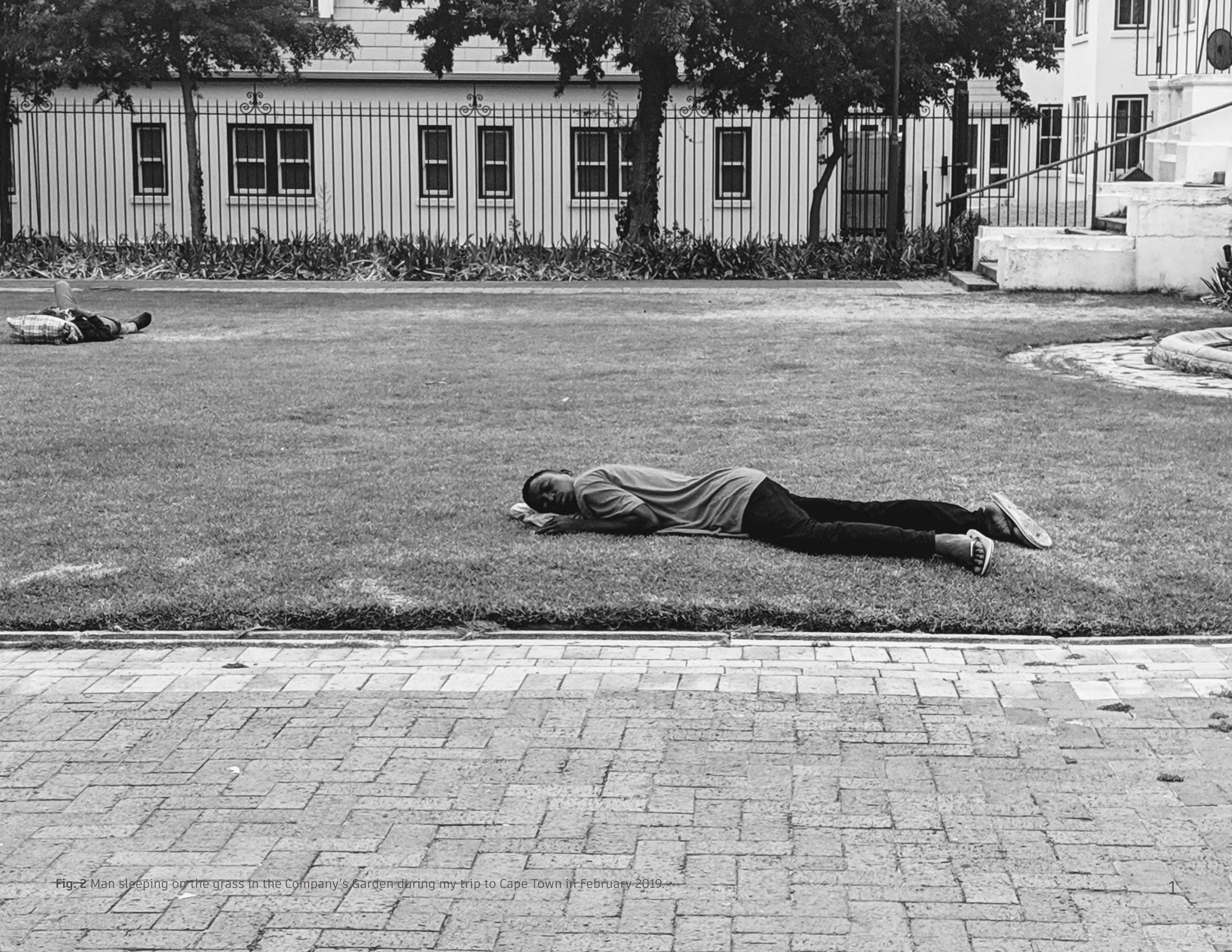




\section{Introduction}

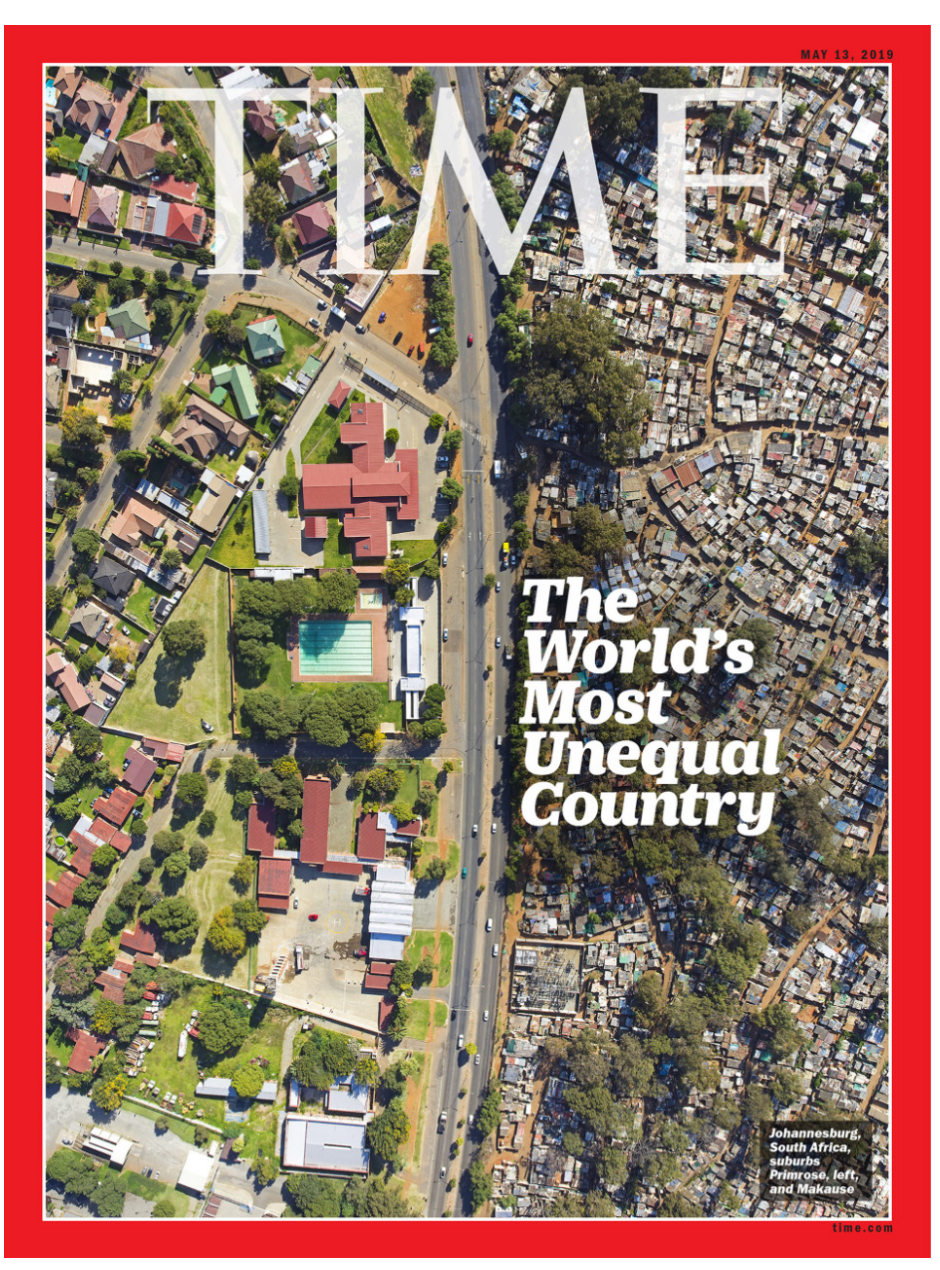

Fig. 3 Time Magazine cover of an 'unequal' South African landscape. https://time.com/5581483/time-cover-south-africa/
Over twenty years have passed since the end of apartheid in South Africa and now more than ever, the spatial politics of erasure, segregation and division are highly visible in both the physical and social landscape, still adversely affecting black and coloured populations. In 2018, World Bank declared South Africa to be the most unequal country in the world. ${ }^{1}$ Because of its unique history in relation to the physical uprooting and relocation of people during apartheid as a form of spatial control, District Six is one of the most compelling sites within which to examine the complexities and contradictions of this newly emerging urban environment of Cape Town.

Situated directly adjacent to the Cape Town City Center, between Table Mountain and Table Bay, District Six has been a site with a contentious and complex historical urban and social fabric that is largely tied to claims regarding the rights to the land. Prior to the forced removals during the apartheid era, District Six housed a community of over 60, 000 multicultural residents, including indigenous Xhosa Bantu, and Indian, Chinese, 


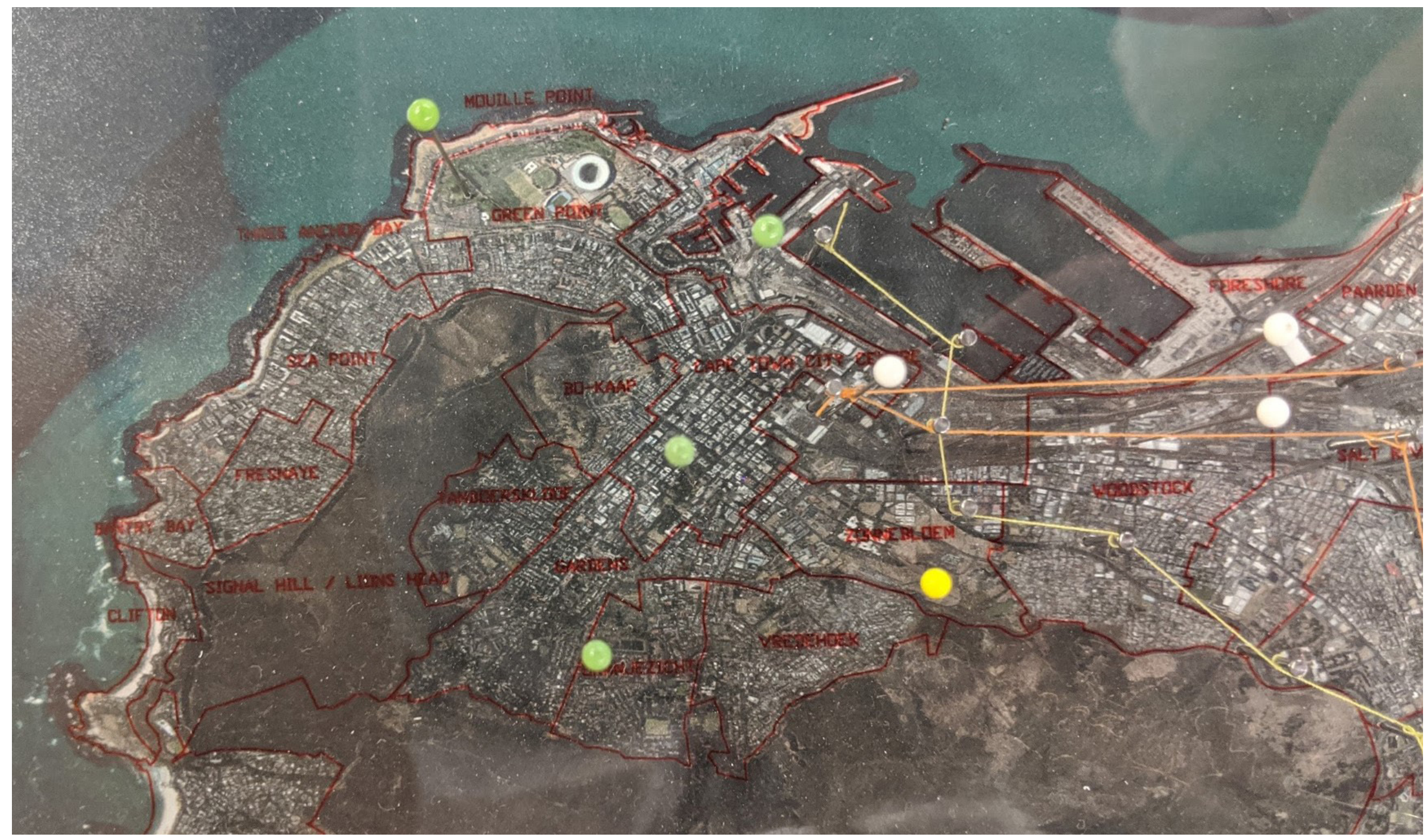

Fig. 4 District Six, now called 'Zonnebloem', is represented by the yellow pin. A fundamental space in the Cape Town city center 
Malay, Jewish and European immigrants. ${ }^{2}$

With the discovery of minerals towards the beginning of the twentieth century, new town planning measures were put in place by the English Empire in order to alter the social, economic and physical structure of the city. ${ }^{3}$ The extremely dense and heterogeneous urban fabric of District Six complicated the desire for a segregated social-spatial order by attributing immoral behavior, values, customs and issues with health, hygiene and the spread of disease to the mixture of color in these congested areas. ${ }^{4}$ The English feared that this spatial and cultural disorder would ultimately lead to a loss of self. ${ }^{5}$ In his book "Building Apartheid: On Architecture and Order in Imperial Cape Town," Nic Coetzer explains "identity is not an essence but is formed through relationships with others; the self is formed by the other, or rather the self is formed not only by what it is, but by what it is not." For the English Empire, the fear of loss of self was threatened by the racial identity of the other, in which civilization, clear ethnic and racial boundaries, the demoralization of white people and the and the loss of power were at great risk. ${ }^{7}$

With apartheid beginning in 1948, District Six became a primary target of spatial control. The implementation of the Group Areas Act of 1950 was the beginning of the forced removal of people, and the demolition and erasure of homes and communities from the site. Defined as a 'whites only area,' the new development of racially specific areas was meant to control the presence of black and colored people in the city, as well as give way for the development of culturally homogenous white spaces which would transform the urban fabric into a 'complete' city of modern progress. ${ }^{8}$ From 1966 onwards, people were removed from District Six and forced to live in townships far outside the Cape Town City Center. ${ }^{9}$ Black residents were sent to the townships of Langa and Guguletu, while colored residents were sent to the townships of Manenberg, Bonteheuwel, Heideveld, Hanover Park and Mitchells Plain. ${ }^{10}$

Today, District Six and its related townships stand 


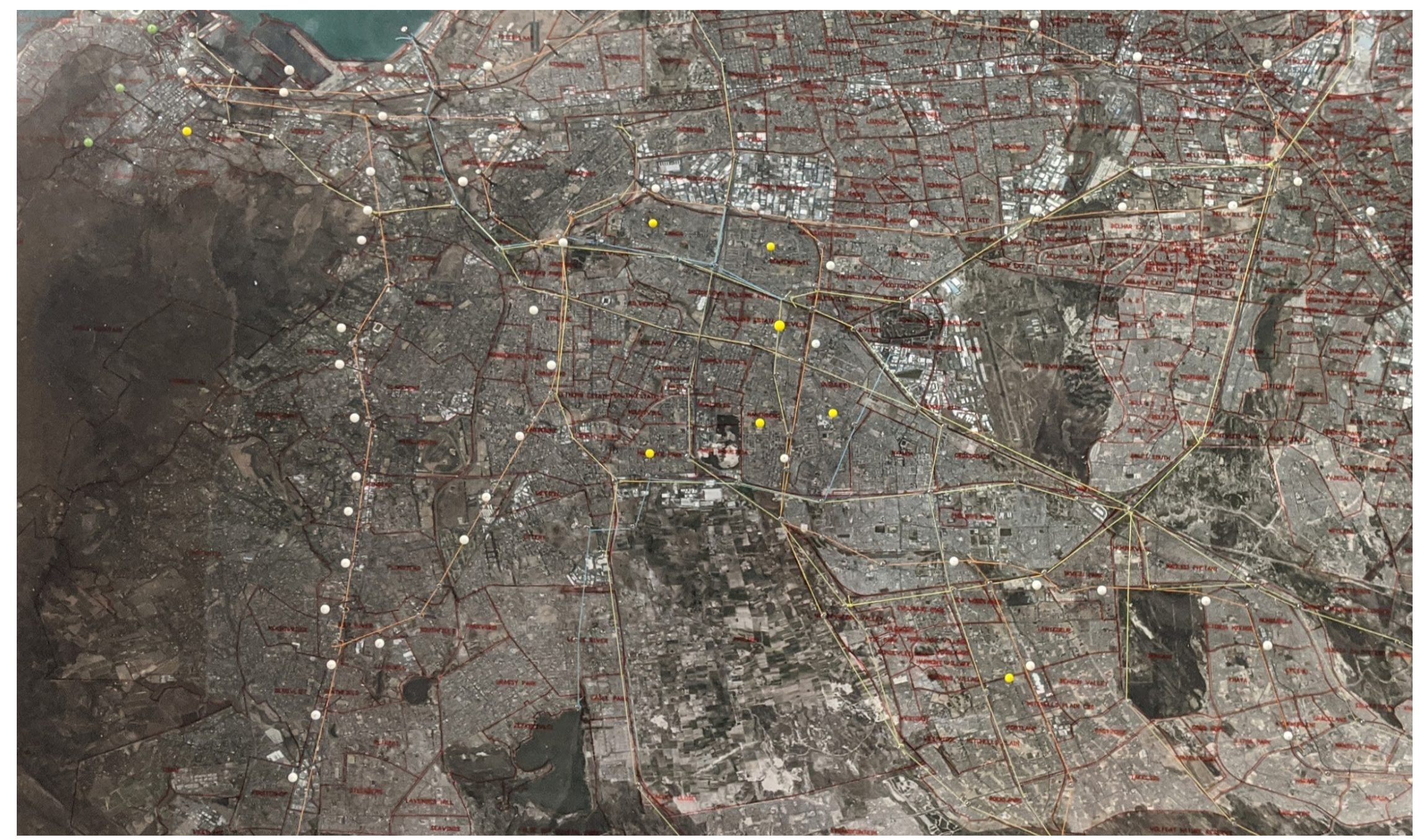

Fig. 5 District Six and its connected townships of Langa, Guguletu, Manenberg, Bonteheuwel, Heideveld, Hanover Park and Mitchells Plain depicted with yellow pins. 
as physical and social scars on the urban landscape of Cape Town. The deployment of urban infrastructures such as the train, highways, land buffer zones and town planning strategies were deliberately used and continue to act to monitor, control and divide the black and colored populations from themselves and ultimately the white city center. ${ }^{11}$ In a sense, District Six was literally and figuratively broken into pieces and redistributed. The separation of resettled townships from the city center has continued through the control of transportation systems and internal planning- a key issue that currently contributes to the continued isolation and social inequality that has become so prevalent in the city. These implicit and explicit forms of control have allowed the unjust violations of apartheid to continue by imposing limitations to the agencies of mobility, voice and view. ${ }^{12}$ As such, District Six can no longer be thought of as a singular site, but rather a fragmented diaspora of what it once was.

In response to this complex set of interwoven circumstances, this architectural proposal explores the role of agency in architecture. This project set out to make visible and empower the residents of the townships to restore the three agencies of mobility, voice and view by re-imagining and redesigning the infrastructure of the train under the following lens: a new, elevated train line as a spatial connection and claim to the land and landscape of the city (mobility); train stations as reenvisioned township cultural centers (voice); and the train car as both a mobile vessel and low-rent facility for offices, public services and vendors (view). This thesis argues that architecture when conceived through these three fundamental agencies, can empower people to regain control of their physical, cultural and sociopolitical identities.

The three agencies of this architectural project are unified through a series of tapestries that are continuously generated by data from the residents of each township above the train stations. In this process, the train car acts as a data collection tool, using WIFI to download data from station to station. Volunteered information from those riding the train such as personal 
thoughts, news, images, community forums and discussions are uploaded to the train station where the data is transformed into a physical tapestry made of coloured and luminescent strings. Within the townships, a series of infrastructural 'needles' are placed which similarly collect data from the residents, as well as provide the strings which stretch in the air above the landscape and converge at the train stations to generate the tapestry.

On the original site of District Six, a station on the historical and central Hanover Street provides a final point for the strings from the townships to arrive to. The strings are fed to needles placed within the site. These needles collect the strings and generate a new fabric which covers the existing landscape of District Six. 
"Eventually they started Silvertree which organised the youth sport like rugby and soccer and whatever.... Most of our games was on the Common."

ry strange, but true. They were facing tiptoed behind them, they all turned ing. 1 actually cried. As if they wanted If that was a pigeon, imagine how we moved us out of our homes. But I em. We forgive them for what they did

\section{Paradise}

Here, around me

they destroy my city

District Six,

they dismantle you

- stone by stone -

rock of my history ${ }^{14}$

Chapter One

The Story of Cape Town's District Six

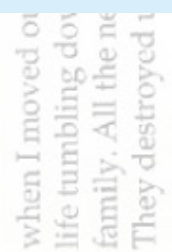

Location Fires?

Beneath my eyelids

\section{the landscape is heavy}

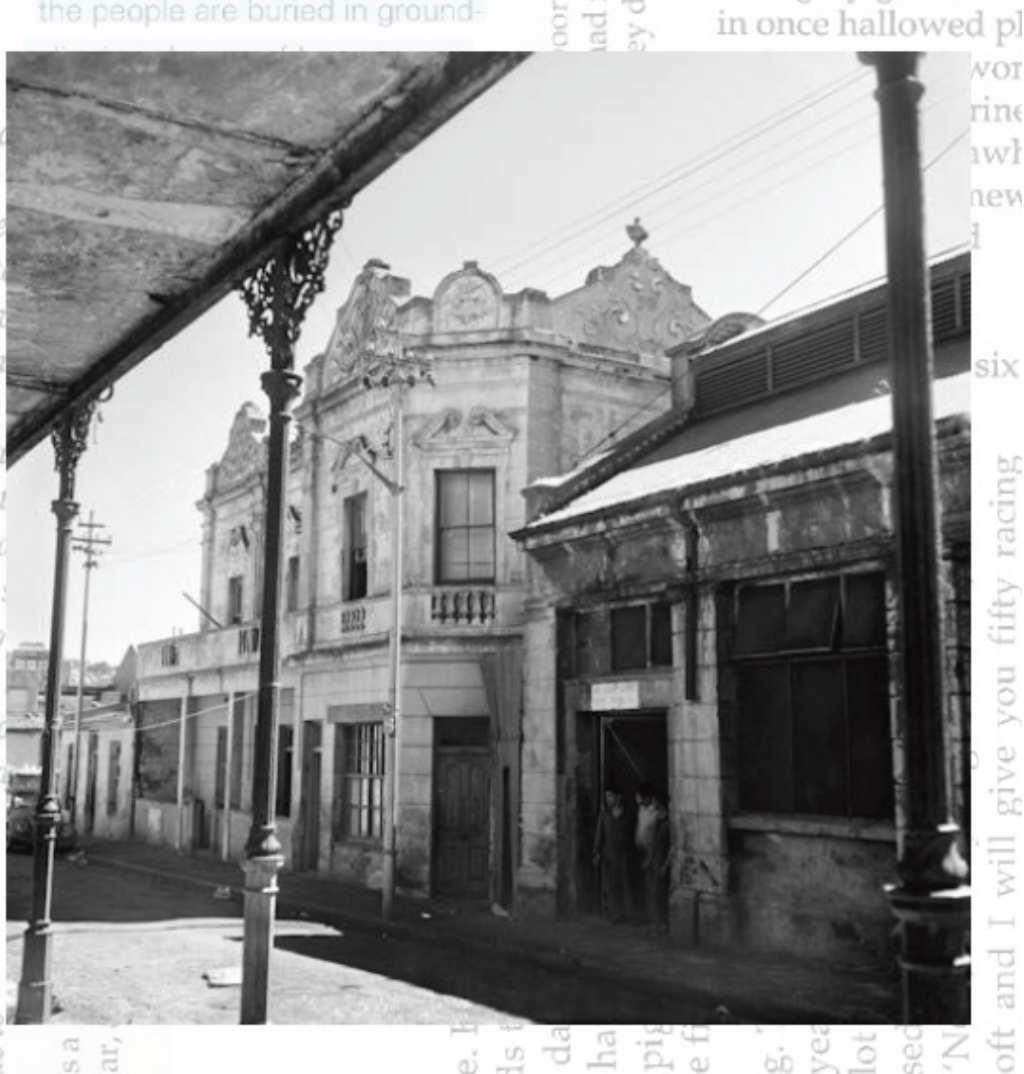

My remaining sister married an also married and left. One did not None of us went in the same dir grown-ut) and gualified and went Christian family in Grassy Park uprooting the way I had. Althougle existed alone with my memories separate area set aside for my se forget the past but the voices caught the house where I was hiding, mov into the lotunge with its stereophoni with its refrigerator and electric sto into my sechded bed-sitting-room. 'They have done this terrible thing see. They have taken your past ar

So I went to see.

Act that moved you from town?"

aalk about it to me. I will cry. I will cry all over again.

it they chucked us out of Cape Town. My whole life in me, in all the people. What they took away they 


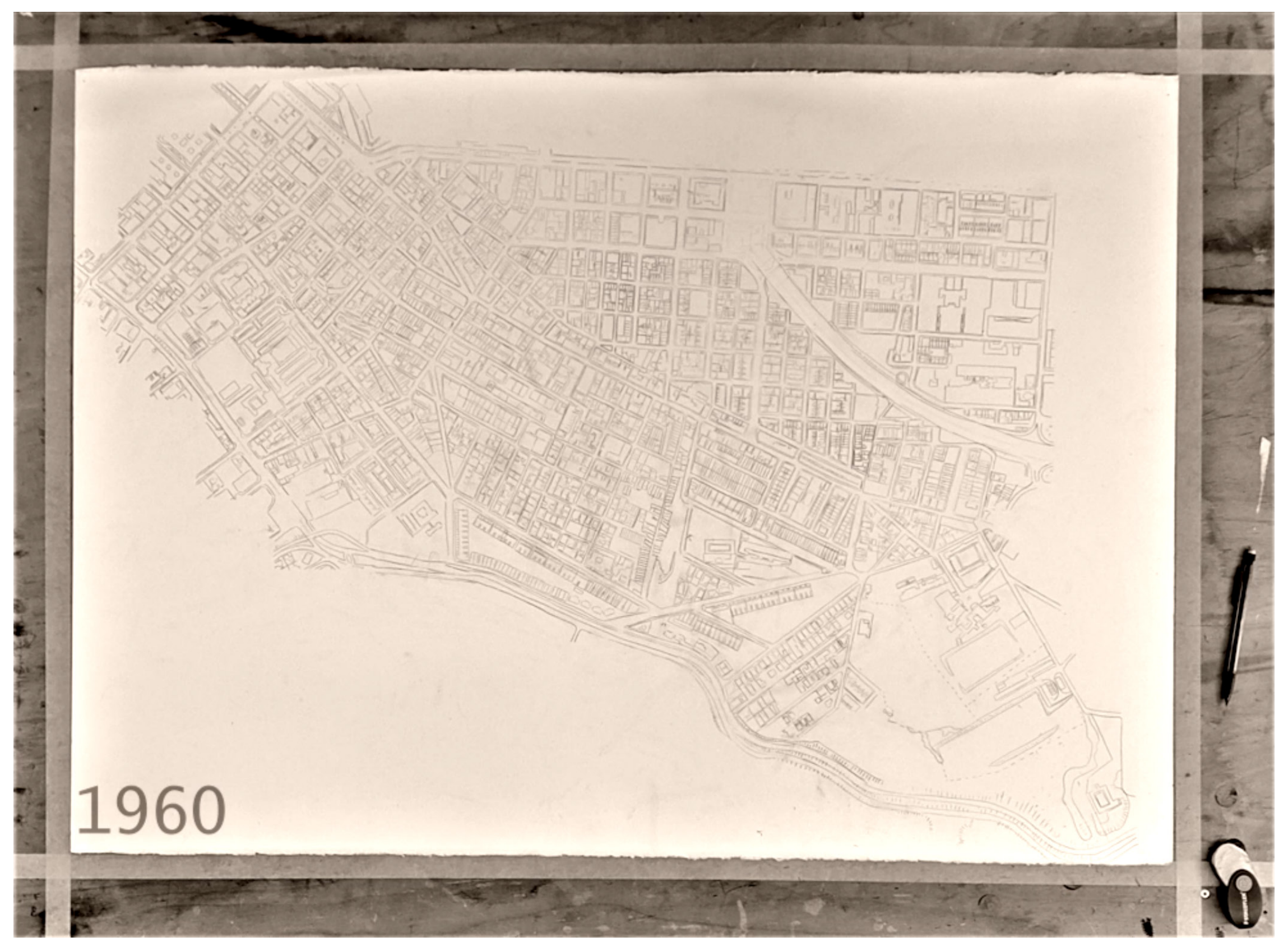

Fig.7 Video Still, District Six prior to the forced removals and site erasure. Please watch: 
The city of Cape Town has undergone many shifting planning and political ideologies since its first permanent settlement by the Dutch in $1652 .{ }^{13}$ Originally inhabited by indigenous Khoisan Pastoralists, the arrival of European ships to Cape Town created an entirely new landscape meant to service the commercial trade of the Dutch East India Company. ${ }^{14}$ Cape Town provided land and resources for clean water, gardens for growing food and farming and materials for building a fort to house its military headquarters, offices, bank, post office and church. ${ }^{15}$ The continued urban development of Cape Town saw with it the expansion of the city and immigration of people from different parts of the world to areas such as District Six.

In 1806, Cape Town came under British rule largely due to the discovery of diamonds, gold and other minerals in Johannesburg. ${ }^{16}$ The mineral revolution quickly became a motivating force for economic and demographic change as rapid industrialization and urbanization created strain on the town's resources. ${ }^{17} \mathrm{By}$ 1892 the English had begun changing the urban strategy by initiating municipal reforms, such as installing water-borne sewage, paving roads, covering over open canals and the building of steel structure Victorian style buildings. ${ }^{18}$ The new town planning measures put in place by the English Empire were meant to order and alter the social, economic and physical structure of the city. ${ }^{19}$

The multicultural population, extremely dense laissez-faire development, hastily constructed speculative housing and lack of an overarching urban plan in District Six complicated the English desire for progress, reform and a social-spatial order. ${ }^{20}$ With them, the English brought the inherent belief of the superiority of British civilization and their duty to spread it throughout the world. ${ }^{21}$ Central to this belief was the idea of the "native question," in which the races of white, colored and native populations each had determined places in society. ${ }^{22}$ Furthermore, it was the duty of the white race to infuse natives with Christianity and civilization so that they might be reformed and emerge from barbarism. ${ }^{23}$ These beliefs proliferated policies of 

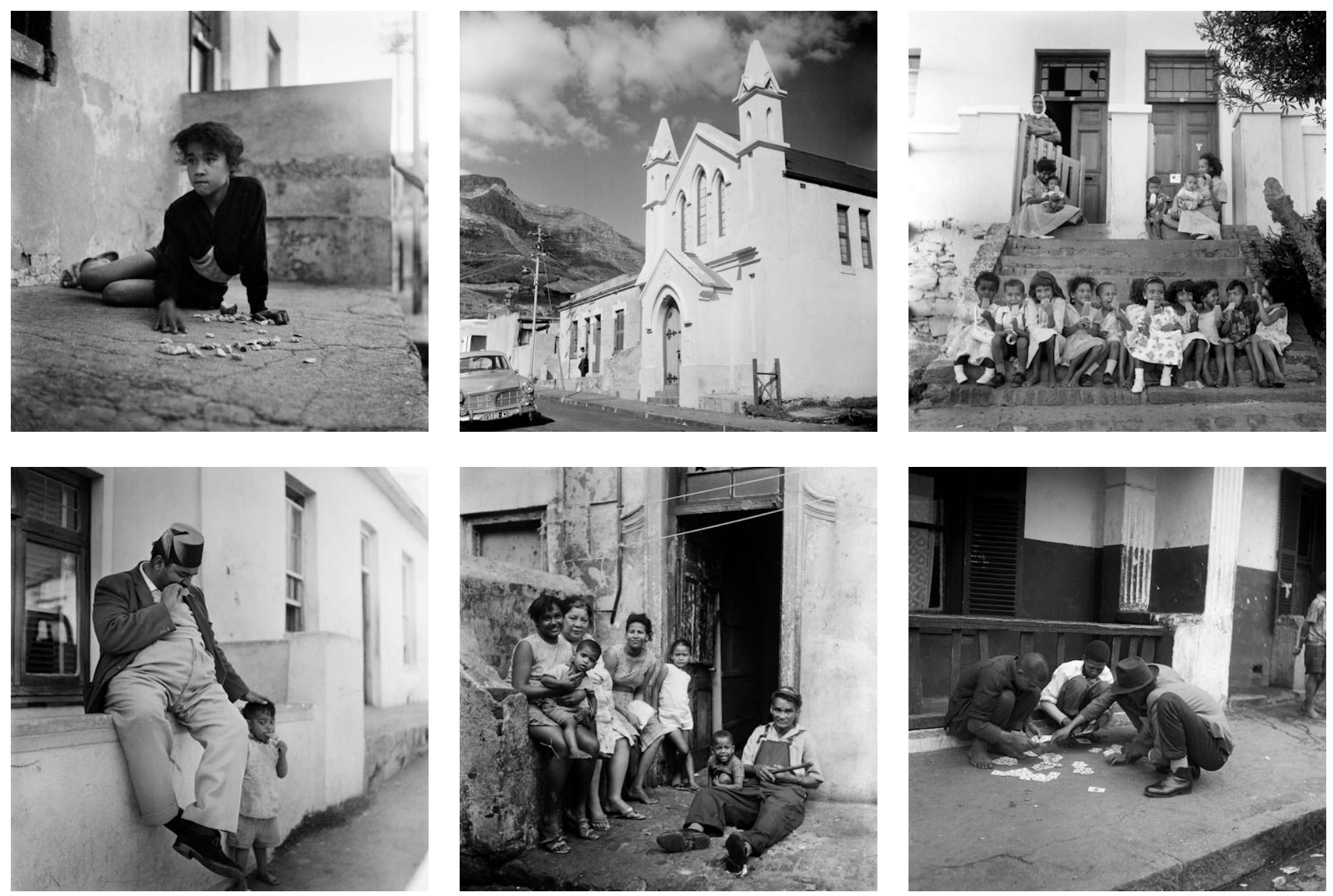

Fig. 8 Photographs depicting daily life and the conditons of District Six prior to the forced removals, taken by the South-African photographer Jansje Wissema.

https://digitalcollections.lib.uct.ac.za/jansje-wissema 
control and the creation of hierarchies of culture and political economy in Cape Town, and more specifically had profound effects on the people and spaces of District Six. $^{24}$

\section{The Influence of the Garden City Movement}

The English desire for social-spatial order in Cape Town can be linked to the ideology of the Garden City Movement which saw a return to the virtues of labor and handcraft after the ravages of the Industrial Revolution. ${ }^{25}$ In England, the Industrial Revolution was seen to threaten the mythology of rural England through factories and mindless production that defiled the land and those who worked in these spaces. ${ }^{26}$ The architectural condition of the city as a place of civic pride and engagement was now viewed as a 'slum,' characterized by shame, demoralizing darkness and danger. ${ }^{27}$

During this time, social Darwinism prompted the idea that the working class was genetically prone to degeneracy and happy to occupy 'slums,' but that an alteration to the physical environment had the potential to manage, socialize and supervise these individuals and improve their physical, spiritual and moral health. ${ }^{28}$ To achieve these goals, city planners such as Ebenezer Howard proposed the idea of a space thatwould balance the benefits of the town and country. ${ }^{29}$ By buying cheap land outside the city and creating new community areas, the overcrowding, poor conditions and poor resources seen in the city center would be eliminated. Furthermore, these areas would allow for funding for improvements and infrastructural upgrades while simultaneously eliminating and collapsing the value of rental spaces in the inner city. ${ }^{30}$

Fundamental to this Garden City ideology was the notion that each individual had a role to play in a carefully structured society, creating a sense of mutual responsibility and obligation. ${ }^{31}$ By recreating the physical structure of the city, inhabitants would be incited to be their better selves, perform their assigned roles and contribute to a settled and organized community. ${ }^{32}$ 


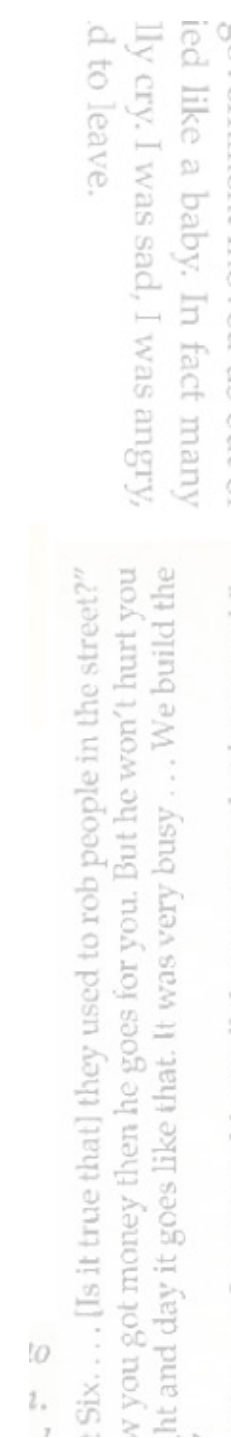

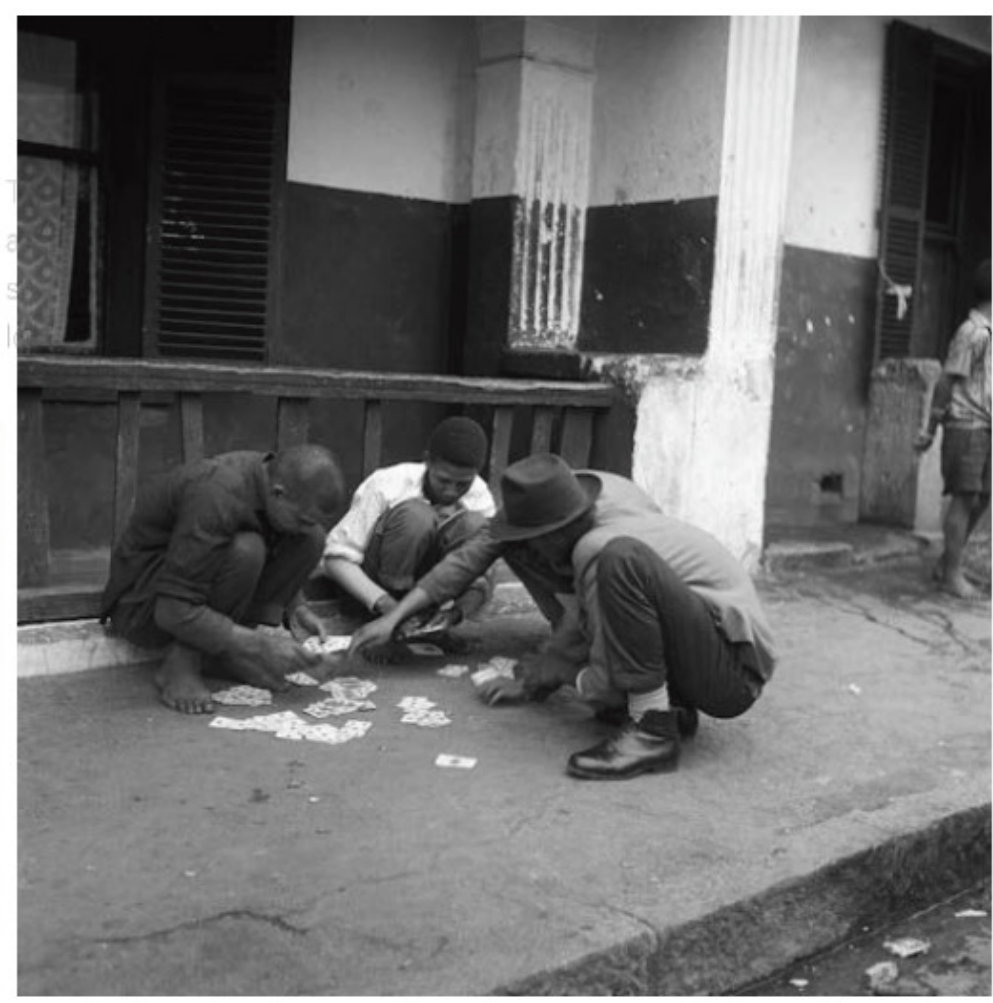

And on Sunday evenings the sun set and threw the sombre landscape into deep, menacing shadow. The lights flickered on in the few remaining houses, and from St Mark's came the thin, organless sounds of evensong. And then the hush of hopelessness descended and the quiet. Few children still played in the streets and fewer made their precarious ways over the scarred land.

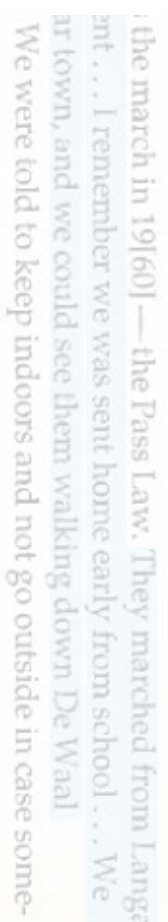

Sunday mornings the church bells of St Mark's still rang out defiantly, reverberating through the empty surroundings and calling to prayer the many who were no longer there. But the faithful heard the bells and came on foot, by bus, by train and by car. The peals reached Manenberg, Cathkin, Kensington and Retreat and people came for their weekly identification with their past. They made their ways over the rubble and stepped over the foundations of the houses they had formerly occupied. I joined in the morning service in the church which no longer had any choir stalls. The stained-glass windows

Fig. 9 Excerpt from Richard Rive, Buckingham Palace District Six, 1986, 72-80. 


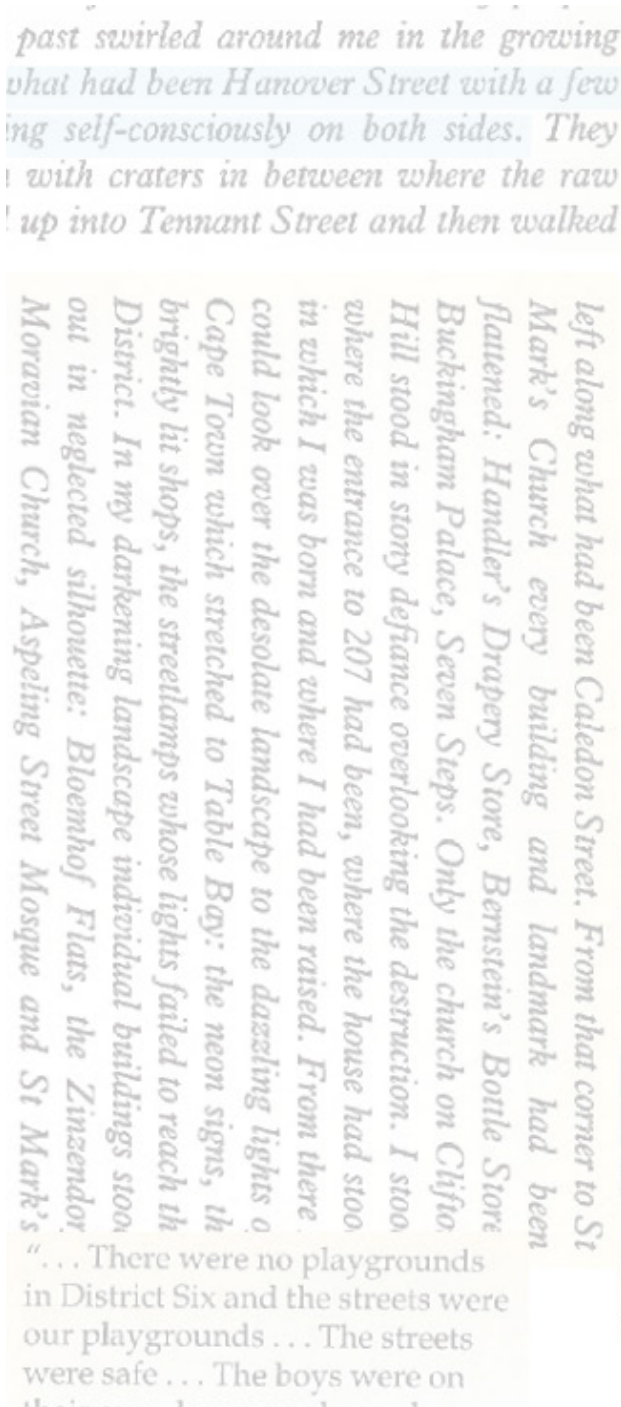

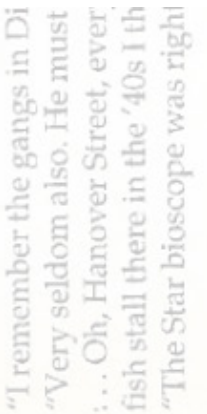

where are the tongues of flame to lick and conquer the dark

responses.

They had taken our past arwary and demolished our spirits and left br. destroyed our community and left dust had done all this for their own selfit They had sought to regulate our prese future. And as I stood there I was over of it all. And I asked aloud, 'What political right to take away a people' answer on that day when they have to past will not be forgotten.' The southaccusation and recrimination into all people had been driven, into the matc and the concrete slabs of Bontehewzel people on the bleak Flats whisper as and intolerance have done to them. An and their children's children because it

Few people were living in the fer which still remained on the lunar landsc remained were people who would not $m$

\section{Death Survey}

From Langa to Nyanga

the fires are hidder

In answer the black body the landscape is flattened

of the sky rears up frightenec and silenced

louc with roaring

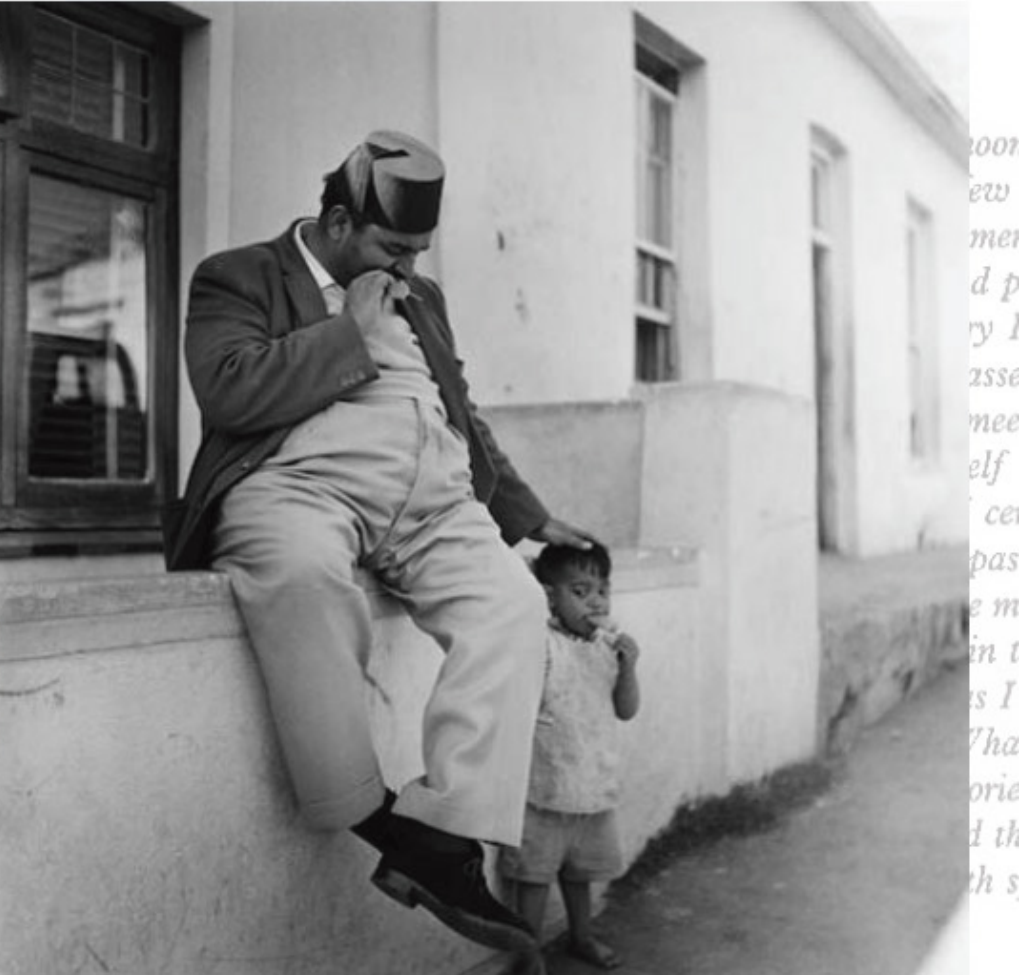

Fig. 10 Jennifer Davids, 'Location Fires' in Chapman, Michael and Dangor, Achmate (eds) (1982) Voices from Within: Black Poetry from South Africa, Johannesburg: Ad. Donker, 97. 
In Cape Town, areas such as District Six were seen to be contradictory to the ideals and town planning focus of the Garden City Movement. With the lack of focus on disposition, grouping of structures, the width and arrangement of the street, the area and proportion of squares and open spaces and the beauty and comfort of parks and gardens, District Six contradicted the English aesthetic sensibility and desire for visual order, and prevented the transference of recognizable English forms in the architecture of the city. ${ }^{33}$ For the visual order of the city to be made apparent, the unruly subjects such as those seen in District Six, would need to be brought in line with eradication of the 'slum' condition. ${ }^{34}$

At this time, the unsightly 'slum' incited notions of the body as a disease or blemish that was in need of surgical incision, referencing the unsightly structures and proximity of the racial and social other that needed to be removed. ${ }^{35}$ Structures that contained corrugated iron were labelled as ugly, and began to conflate the visual appearance, materiality and physicality with the social and racial otherness of those in District Six. ${ }^{36}$
The English also ascribed an animal status to the 'slum dwellers' of District Six by describing their spaces as 'hovels' like the dens and kennels of animals such as rats. ${ }^{37}$ Like the social Darwinism that prompted ideas about the working class in England, the native and colored populations of District Six were thought to be prone to living in these congested and overcrowded conditions as they were naturally unable to live in order. ${ }^{38}$ 'Hovels' were further conflated with a particular kind of unfathomable person or degenerate as high density living became akin to skin color, language and dress. ${ }^{39}$ Seen as racially inferior, the designation of these individuals as animal-like created the idea of a condition that needed to be controlled and eradicated..$^{40}$ To add to this notion, fears of miscegenation through contact and the interracial mixing of people complicated the English desire for a social-spatial order as the loss of racial identity and clear ethnic boundaries was a cause of social degradation for all. ${ }^{41}$ The 'slum' of District Six threatened the English notion of the loss of self and civilization as it was ascribed as a location of 'otherness.' 42 By stigmatizing and devaluing the site, 


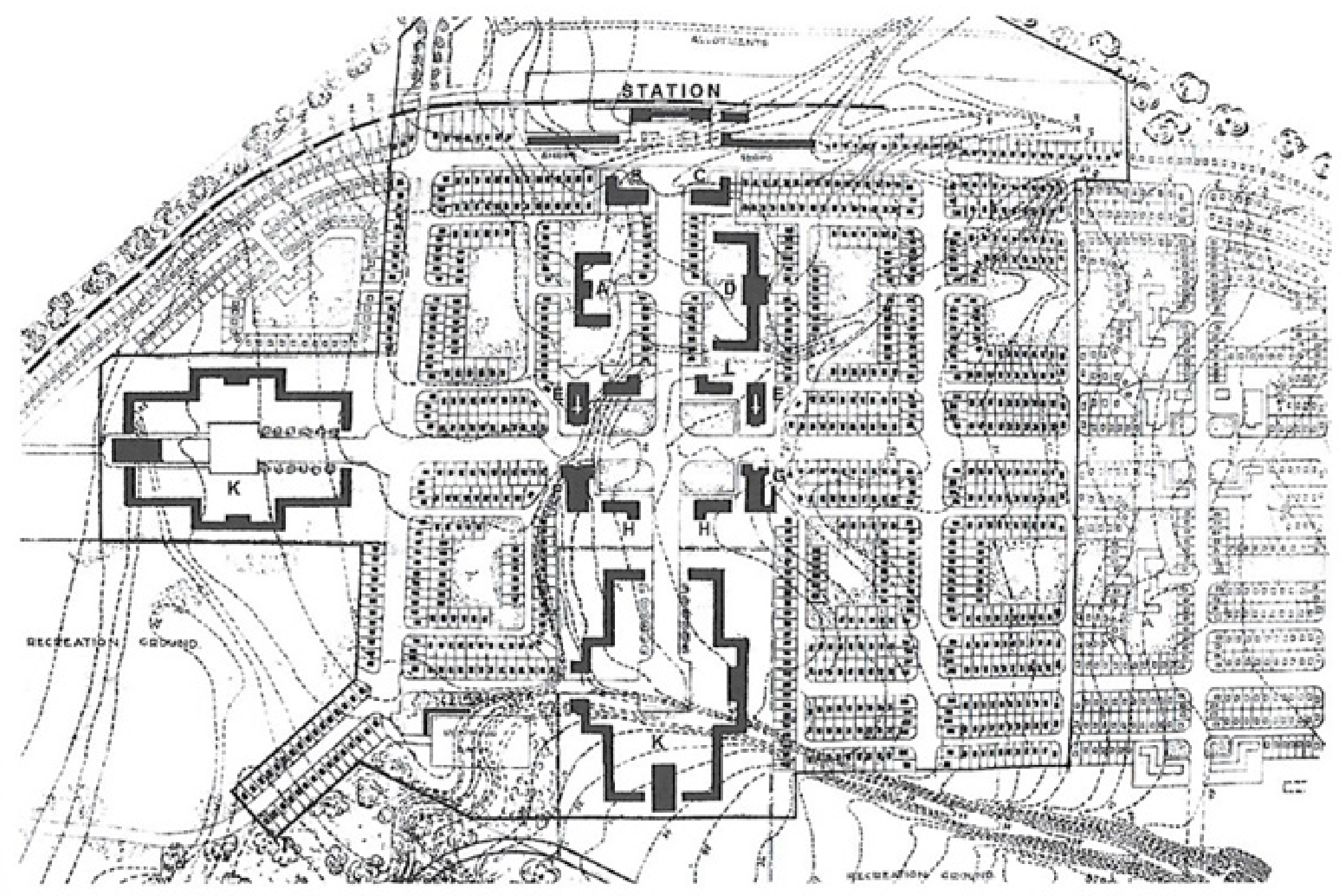

Fig. 11 A map of Langa Township layout from 1923 in Nicholas Coetzer, Building Apartheid: On Architecture and Order in Imperial Cape Town. Surrey: Ashgate, $2013,195$. 
both inhabitants and buildings were opened up to the possibility of forced removal, a thought which would later become reality. ${ }^{43}$

\section{The Case of Langa Township}

During apartheid, some black residents of District Six were moved to an area eight kilometers outside the city center known as Langa Township. Langa stands as a result of the spatial strategies of the Garden City Movement which imagined the area as a 'native village.' This village would save and uplift the working class of black and colored residents from the temptations of the city. ${ }^{44}$

At the time, the township included administrative quarters, a hospital, school, police station, shops and different living quarters to house both married and single residents. ${ }^{45}$ Its formal and orthogonal civic and commercial axis, flanked by the train station on the perimeter of the township, created highly organized and separate areas for different groups of people. ${ }^{46}$ In addition, the rigid masterplan of the site emulated the panoptic surveillance systems of prisons seen in the nineteenth and twentieth centuries. ${ }^{47}$

This apartheid strategy of spatial control has continued to exclude the residents of Langa and the other townships of Guguletu, Manenberg, Bonteheuwel, Heideveld, Hanover Park and Mitchells Plain from the space of the Cape Town city center. The forced removal of the residents from District Six and the subsequent spatial strategies of the townships contributed to erasing three critical agencies of these individualstheir mobility, voice and view. Erasure in this sense acts as a lens in which to examine, interrogate and propose ideas for how to restore these three agencies. 


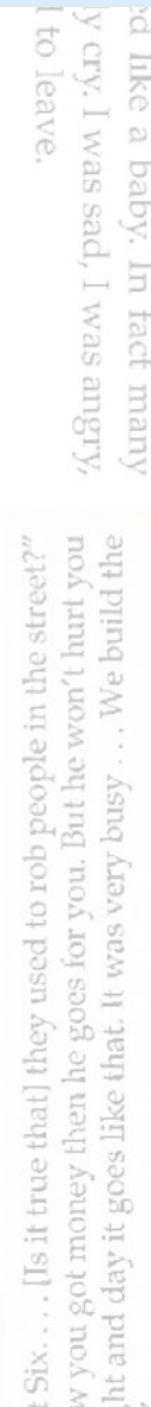

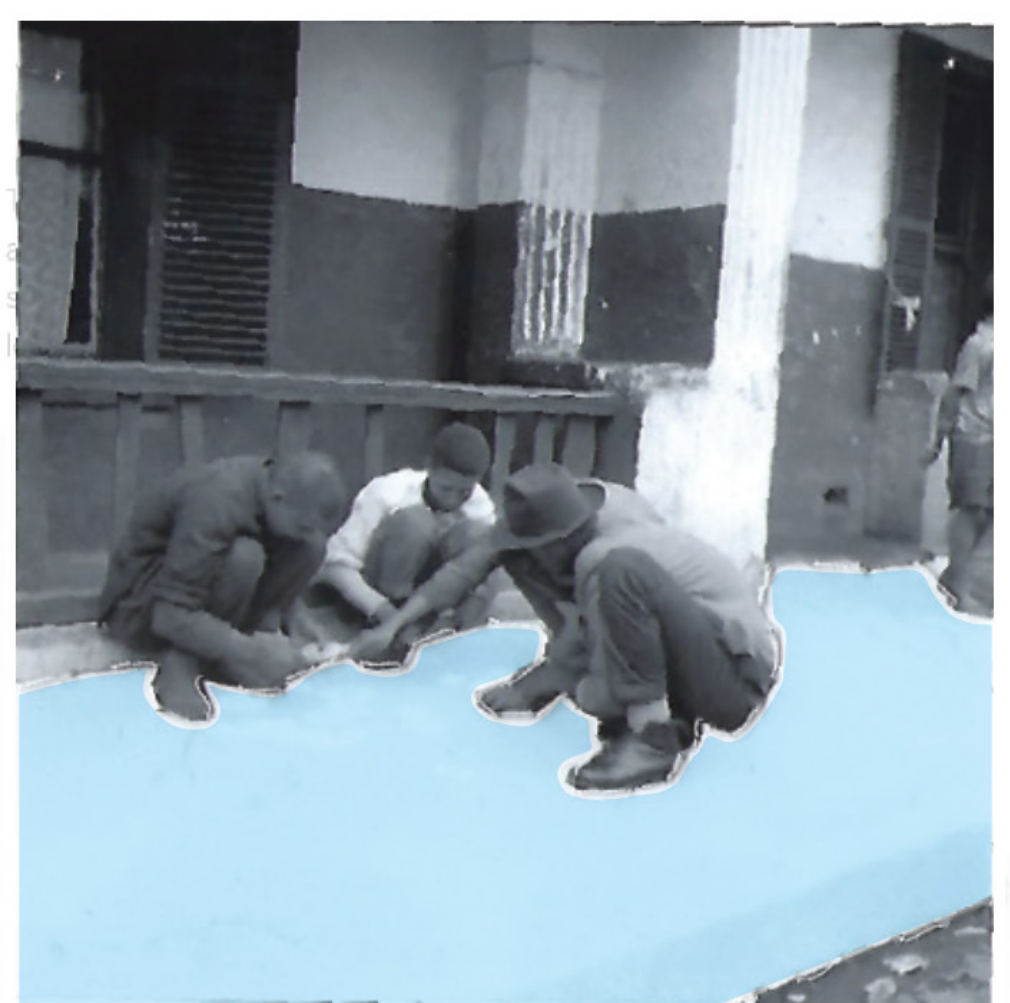

And on Sunday evenings the sun set and threw the sombre landscape into deep, menacing shadow. The lights flickered on in the few remaining houses, and from St Mark's came the thin, organless sounds of evensong. And then the hush of hopelessness descended and the quiet. Few children still played in the streets and fewer made their precarious ways over the scarred land.

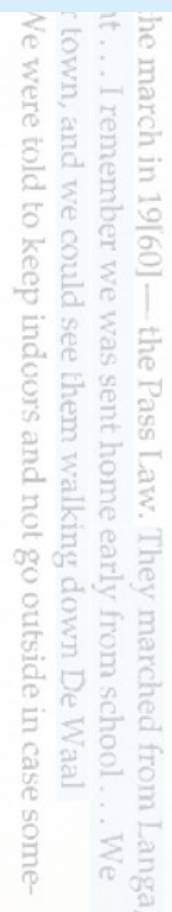

Sunday mornings the church bells of St Mark's still rang out defiantly, reverberating through the empty surroundings and calling to prayer the many who were no longer there. But the faithful heard the bells and came on foot, by bus, by train and by car. The peals reached Manenberg, Cathkin, Kensington and Retreat and people came for their weekly identification with their past. They made their ways over the rubble and stepped over the foundations of the houses they had formerly occupied. I joined in the moming service in the church which no longer had any choir stalls. The stained-glass windows 


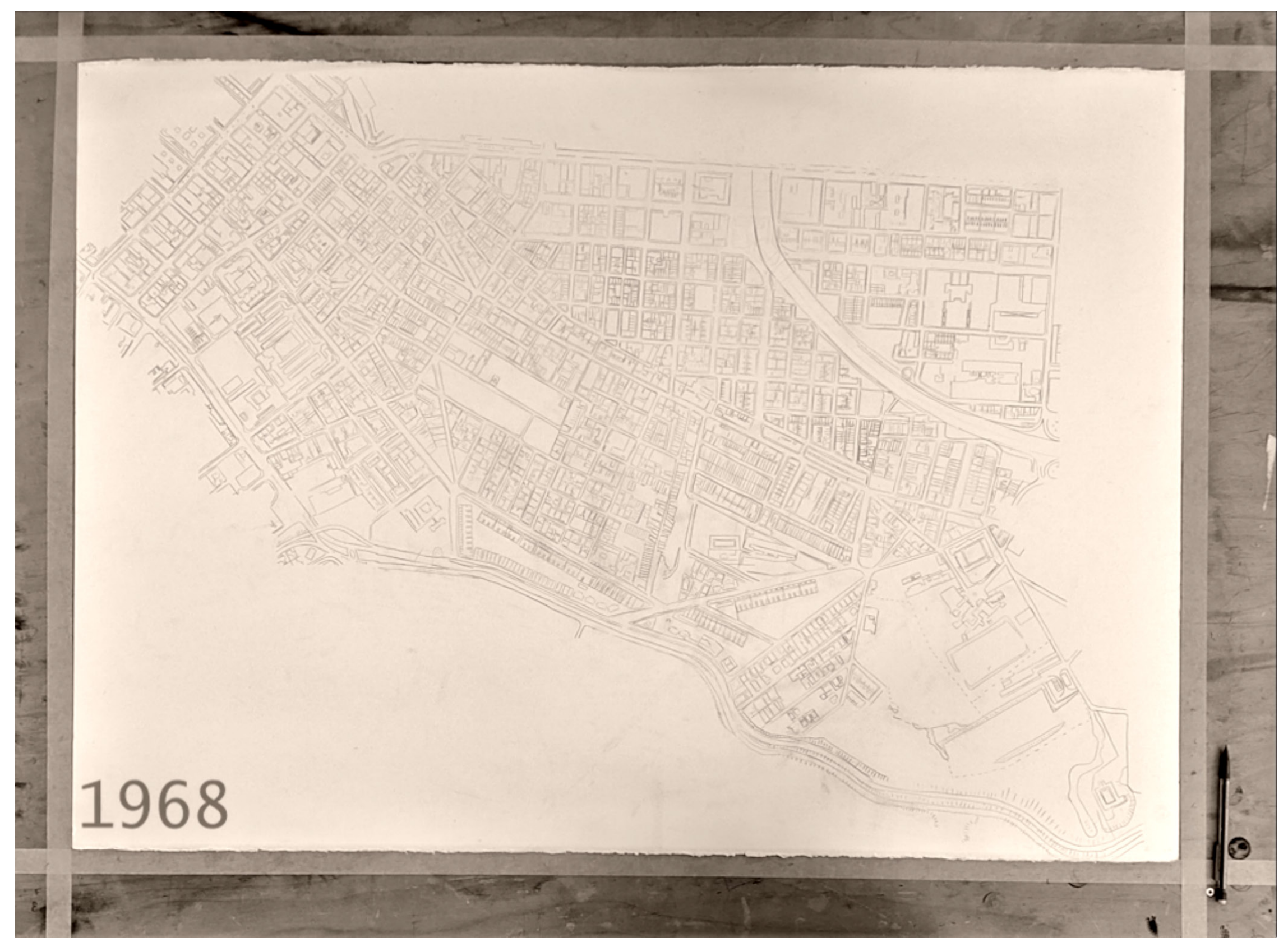

Fig. 13 Video Still, the beginning of the erasure of District Six. 
During the nineteenth century, District Six became a fundamental part of the urban fabric of Cape Town. The discovery of gold and diamonds in Johannesburg brought people from all corners of the globe including Eastern and Northern Europe, India, China and Australia. ${ }^{48}$ The close proximity of District Six to public services, employment opportunities, local industries and the dock provided the perfect location for these residents to live. ${ }^{49} \mathrm{~A}$ sense of community also evolved in this place with the development of shops, schools, places of worship and community facilities. ${ }^{50}$

However, as the space became more populated, congestion and overcrowding started to become an issue. ${ }^{51}$ Problems with sanitation, drainage, disease and increasing rent rates, a shortage of housing and low wages adversely affected the living conditions of the residents. ${ }^{52}$ For the apartheid government, District Six was seen as a site that needed to be cleared and redeveloped. ${ }^{53}$ In 1950, the Group Areas Act designated District Six as a 'whites only area,' and by 1969, 18,000 residents had been removed and sent to live in the townships. ${ }^{54}$ By 1976, after multiple attempts to redevelop the area, 2/3 of residents had been removed and multiple residences and buildings had been demolished. ${ }^{55}$ By 1978, a total of 60,000 residents had been forcibly removed from the space of District Six.

The forced removal and relocation of residents from District Six and the demolition of residences and buildings was part of an instrument of control and humiliation used in apartheid spatial politics. ${ }^{56}$ The apartheid government similarly introduced many other spatially motivated tactics having to do with the control of borders including racially discriminatory laws, administrative boards, a commission of inquiry, town planning schemes, health regulations, pass books, spot fines, location permits and police raids. ${ }^{57}$ Furthermore, places such as registration offices, health clinics, post offices, recruitment bureaus, hostels, servant rooms, police cells, court rooms, park benches and beer halls all became sites of regulation and surveillance. ${ }^{58}$

In the relocated townships, races were 

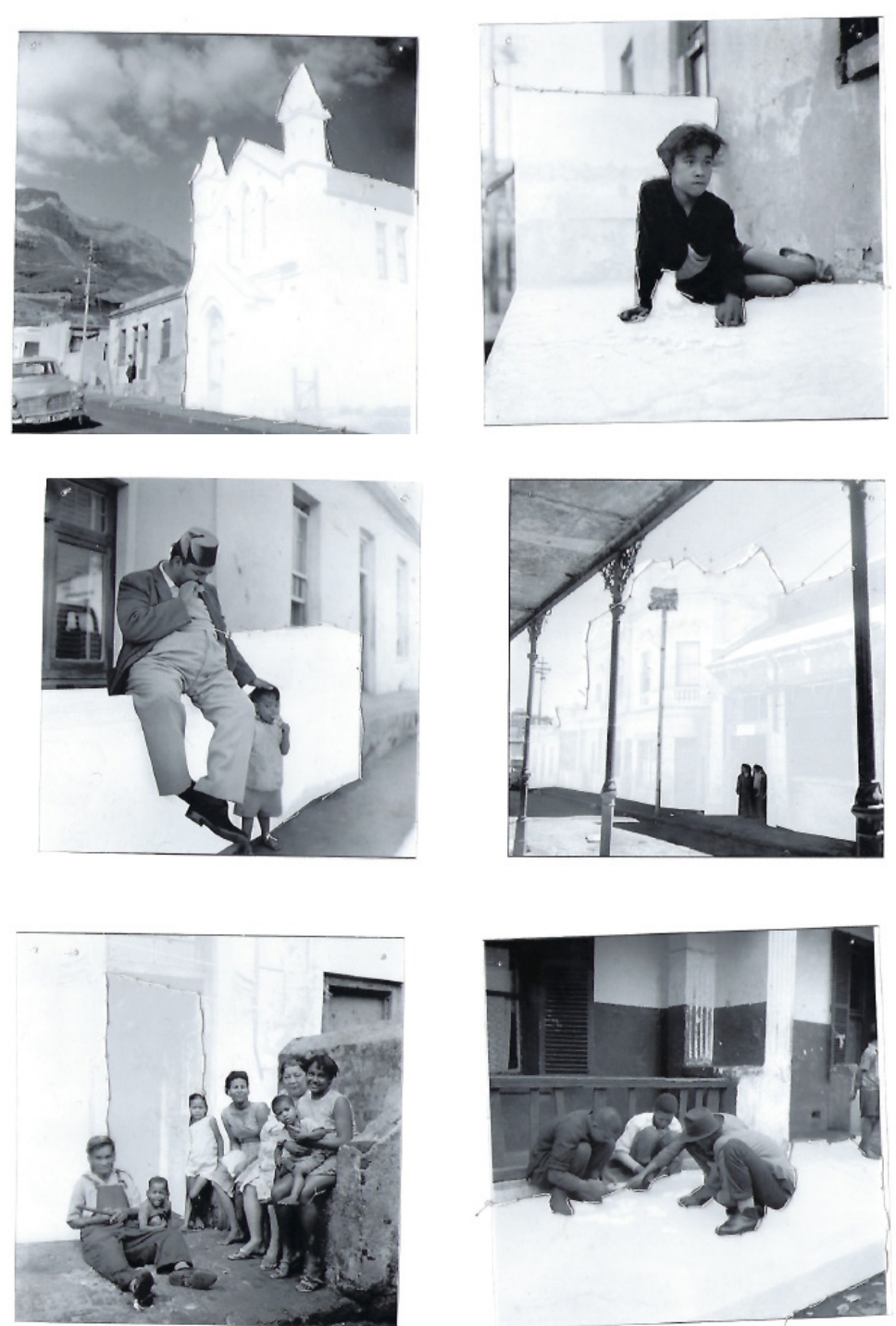

Fig. 14 Jansje Wissema photos with an erased element and stitched outline. 
consolidated in their own independent residential areas. $^{59}$ Separated by natural barriers such as rivers and edges such as highways, rail and open space, these individuals were not permitted to cross from one residential area to another. ${ }^{60}$ The aim of these borders were not only to set these racial groups apart, but to control and regulate these bodies in terms of movement, occupation and labor. ${ }^{61}$

The contradictions of apartheid were evident in the notion that black and colored bodies were not a legitimate part of the city, but were necessary for the labor to create and sustain it. ${ }^{62}$ This tactic affirmed to these people the temporary status of their occupation in the city space as coming into the city always involved a return to space outside its formal limits. Then and now, the relationship of the past residents to the city center is one in which the act of travelling to and from the city is a daily re-enactment of the forced removals, and one which reinforces their lack of claim to its land.

\section{The Influence of the Garden City Movement}

The city that emerged under the Group Areas Act of 1950 was one that reflects the attempted erasure of its black and colored inhabitants. Ideas of both 'land' and 'landscape' provide further understanding of the repercussions of apartheid spatial politics and the types of erasures that occurred. In Jennifer Beningfield's book "The Frightened Land," she describes 'landscape' as spaces, buildings and land that are embedded with economic, political, cultural, physical and spatial practices that impact and are impacted by the bodies of its inhabitants and that act as a way of seeing and communicating meaning. ${ }^{63}$ In comparison, 'land' is a space of inhabitation that is not dependent on representation, but instead reflects a direct and unmediated interaction with aspects of the natural world. ${ }^{64}$

Thinking about District Six in the context of these definitions, the displacement of people from 


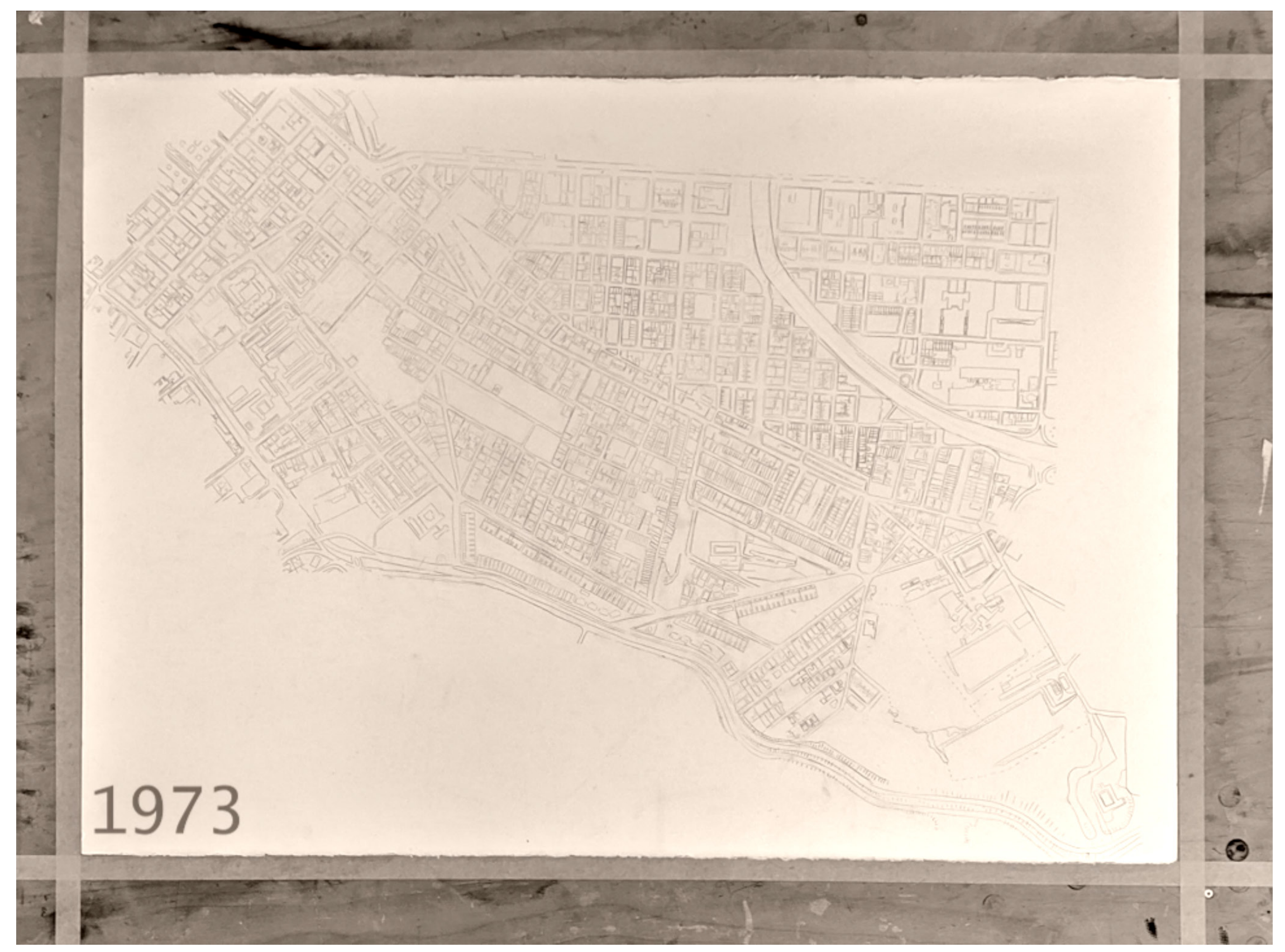

Fig. 15 Video Still, the continued erasure of District Six. 
their spaces of inhabitation transformed these physical spaces, erasing physical traces of their occupation as well as the cultural, social and economic meaning of the former landscape. ${ }^{65}$ Through the removal of people and space over time, the movement, interaction, exchange and spaces that reflected cultural identity of the inhabitants of District Six changed. Once understood at a human scale, the inherently large scale of the emptiness of the land was now void of meaning.

Within the townships, the displacement of people to the barren, infertile and undifferentiated land of the townships created a feeling of homelessness in which residents mourned the loss of the community and place of District Six. ${ }^{66}$ Through a lack of cultivation of place and familiar landscapes, as well as the disconnection from the presence of the site, the past residents of District Six and their next generation will continue to lack a sense of home and a feeling of belonging. ${ }^{67}$

Present day, the original site of District Six exists as empty canvas, a reminder of the potential possibilities

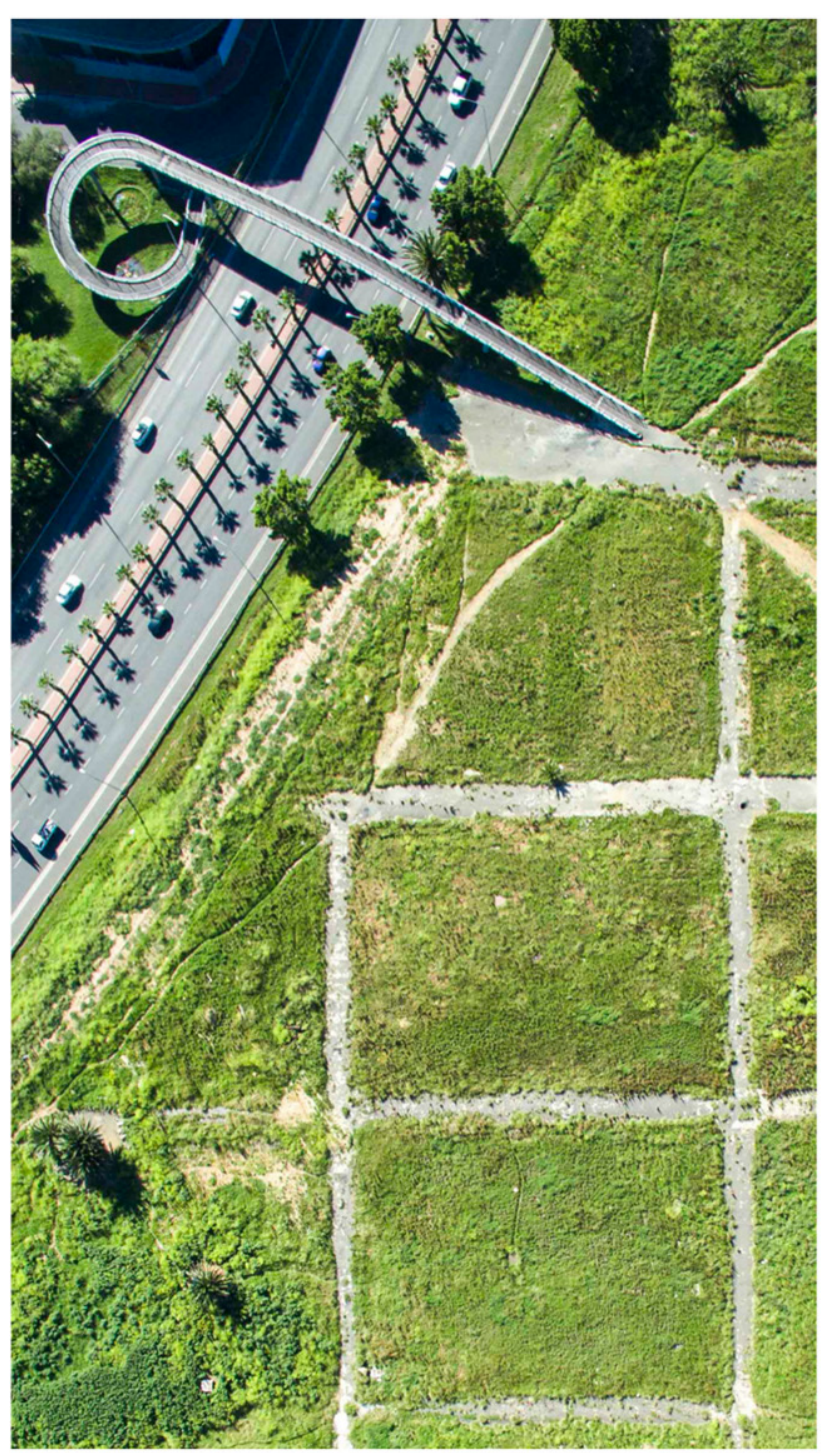

Fig. 16 Outlines of demolished spaces in District Six. https://unequalscenes.com/south-africa 


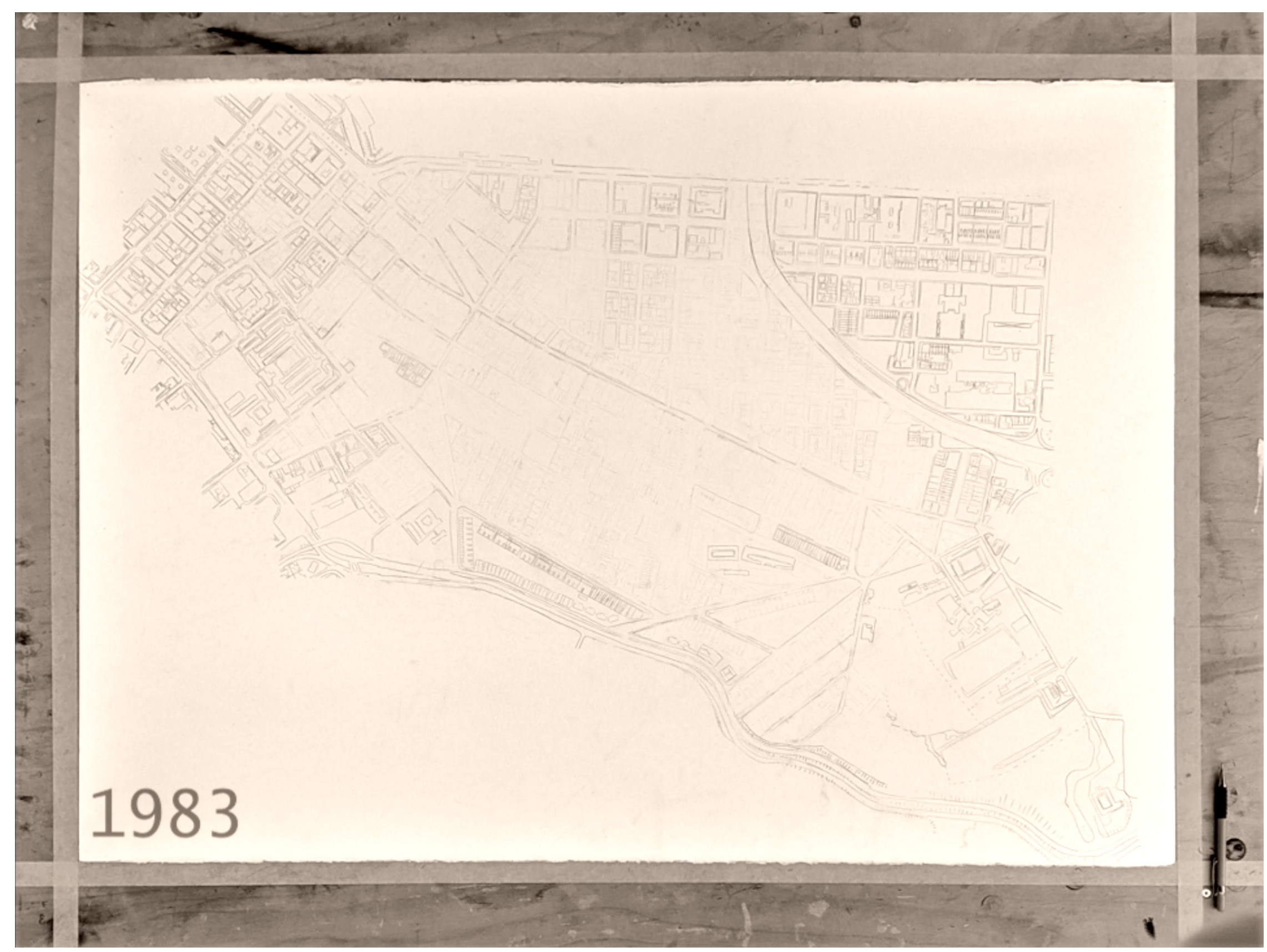

Fig. 17 Video Still, District Six erased. 
for the urban landscape of Cape Town. Many large, expansive spaces remain barren, while others have been built upon. The Cape Technikon, originally a whitesonly technical university, was built in the 1980's as an oversized space in order to cover as much land as possible, and continues to stand in the center of District Six as a reminder of the apartheid era, and as a physical divider of the spaces that remain. ${ }^{68}$ Other various businesses remain condensed on the edge of the district, ultimately working to serve the city outside of it. Within District Six many roads, lanes and homes have been erased, with some trace scars visible, showing what has been lost. Overall, District Six stands as a fragmented landscape, bearing traces of its complex and multi-layered history.

\section{Restitution Rights}

Through the years since apartheid, there have been many different claims over the rights to District Six. In 1994, The Restitution of Land Rights Act 22 addressed claims based on the dispossession after the passing of the Land Act of 1913. The aims of the act are as follows:
1. To promote justice in respect of all victims of dispossession of land rights as a result of racially discriminatory laws or practices.

2. To facilitate negotiated settlements, bringing together all stakeholders in matters related to land claims.

3. To foster and nurture a spirit of reconciliation through the restitution process among those who use the land and within the nation at large. ${ }^{69}$

This act, which allows for different types of compensation of the land, is mainly interested in its restoration:

Restoration of the land from which claimants were dispossessed

Provisions of alternative land

Payment of compensation

Alternative relief including a combination of the above mentioned, sharing of the land or budgetary assistance such as services and infrastructure development; or Priority access to state resources with regard to housing and land development programs ${ }^{70}$

Even with The Restitution of Land Rights Act 22, 


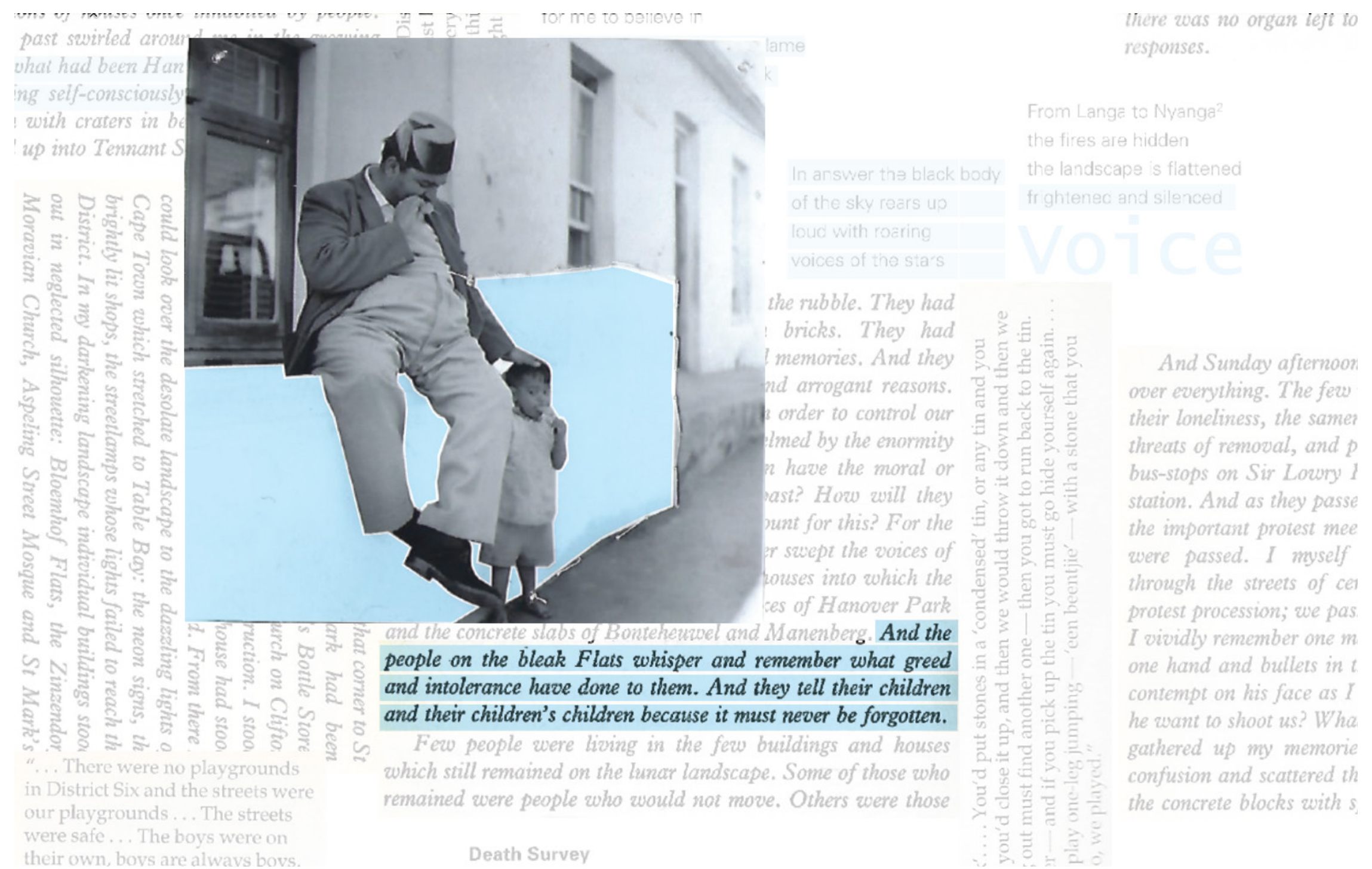


there continues to be conflict over claim to the land. The officials who currently own the land and claim right by power and office are in direct dispute with the people who are claiming right by public acclaim. ${ }^{71}$ In 2003, work began on the construction of 24 new houses, and in 2004 Nelson Mandela handed keys to the first residents to come back to the site. ${ }^{72}$ Even with this positive step forward, conflict remains an ongoing issue with accusations of the state stalling the restitution process. $^{73}$

In the context of the erasure of District Six, The Restitution of Land Rights Act 22, does not address what was erased from the 'landscape' such as the culture, history and memories of the displaced residents. Instead, it speaks to the 'land,' acknowledging the physical elements that were lost and the people who were displaced. In this sense, this reconciliation is limited in that it can never capture or understand the extent of what was erased. This understanding is something that can only be expressed by the past residents. To propel the residents of District Six forward, there must be steps taken towards agency, to give them the opportunity to express their own histories, identities and desires for the future. 
Chapter Three

Paradise

Here, around me

they destroy my city.

District Six

they dismantle you

- stone by stone

rock of my history ${ }^{14}$

Fventualiy they

started Silvertree

which organised the

youth sport like

rugby and soccer and

whatever.... Most of

our games was on the

Common.

ry strange, but true. They were facing tiptoed behind them, they all turned ing. I actually cried. As if they wanted If that was a pigeon, imagine how we moved us out of our homes. But I em. We forgive them for what they did

My remaining sister married an also married and left. One did not None of us went in the same dire grown-up and qualified and went t Christian family in Grassy Park uprooting the way I had. Although existed alone with my memories in eparate area set aside for my sepco erget the past but the voices caush the house where I was hiding, moz into the lounge with its stereophonic with its refrigerator and electric sto

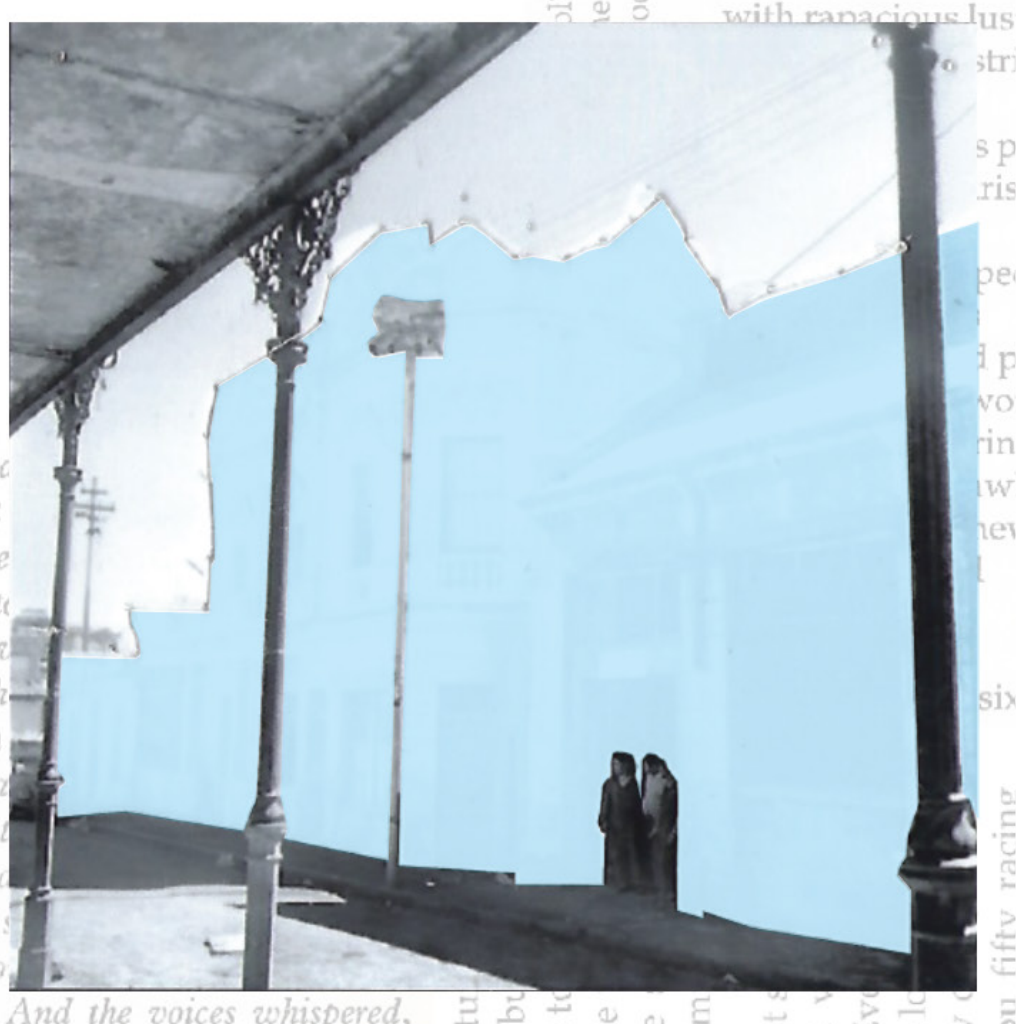

'They have done this terrible thing to you, to all of you. Go and see. They have taken your past away.'

So I went to see.

Act that moved you from town?"

alk about it to me. I will cry. I will cry all over again.

they chucked us out of Cape Town. My whole life $t$ in me, in all the people. What they took away they

$\sum_{0}^{\infty} \equiv$

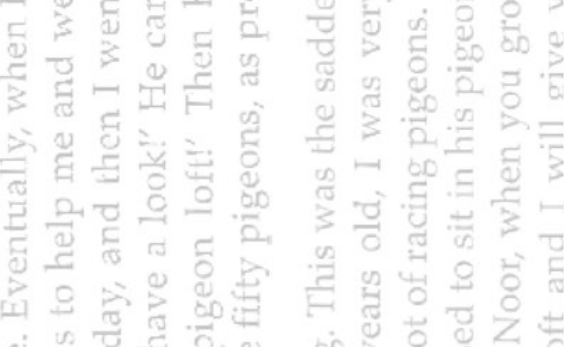

Fig. 19 Excerpt from Richard Rive, Buckingham Palace District Six, 1986, 72-80. 


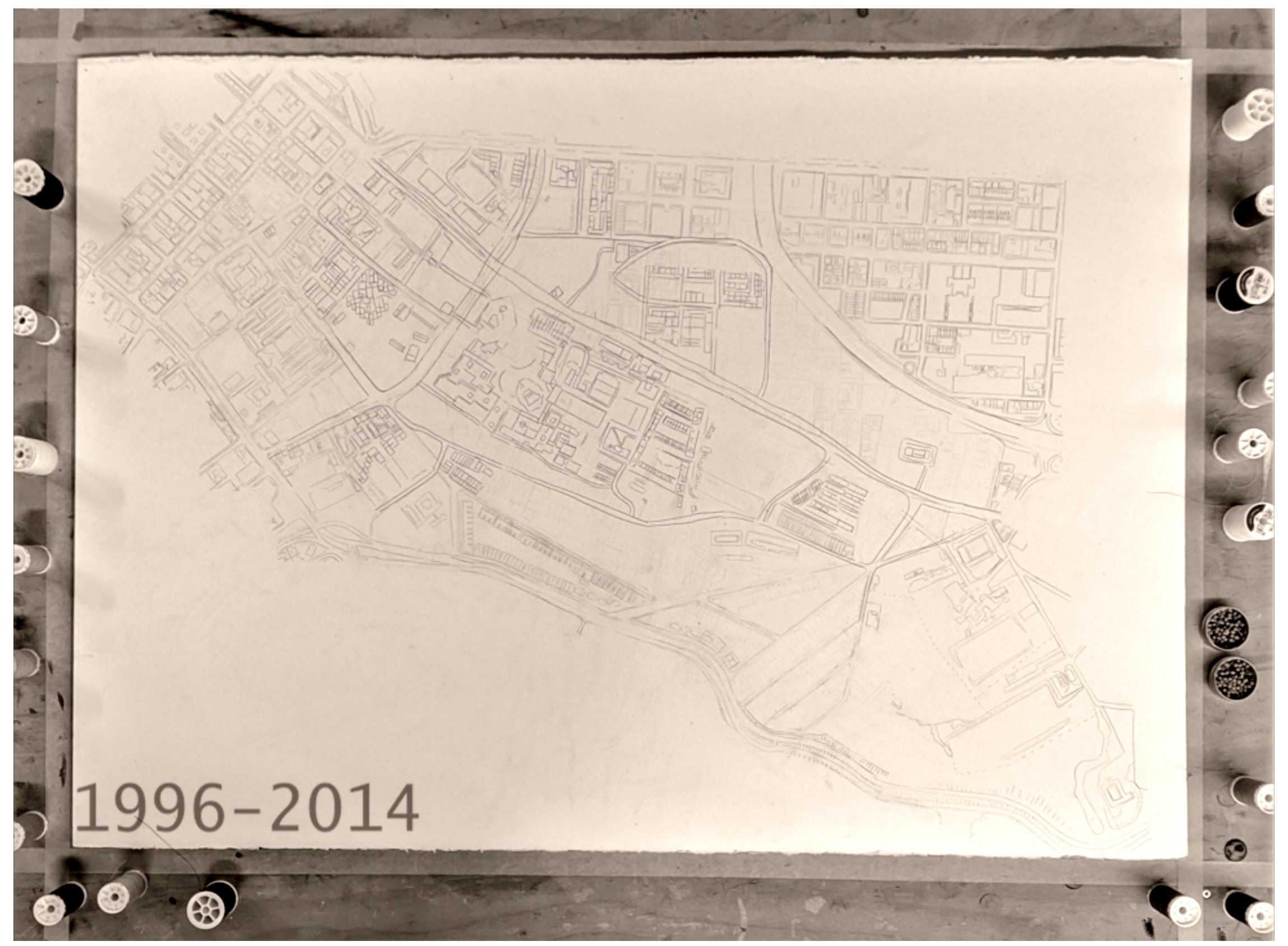

Fig. 20 Video Still, District Six in present day. 
The Erasure of Mobility

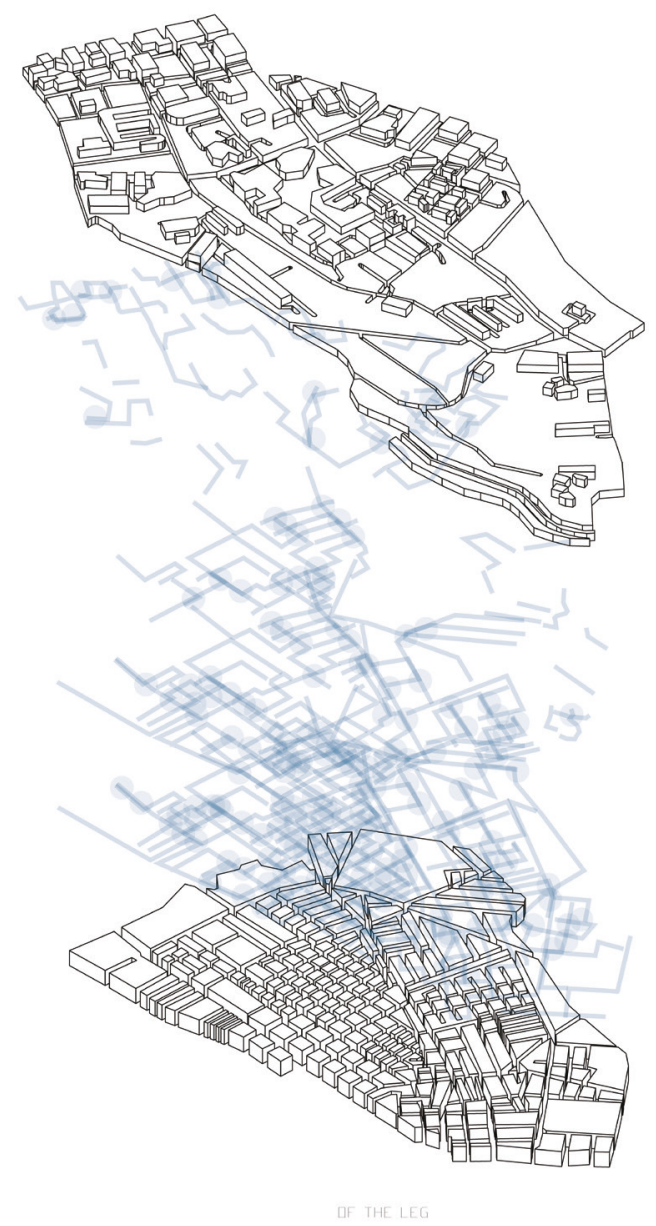

Fig. 21 Conceptual representation of the erasure of 'mobility.'
What does it mean to erase people from a city? How does it affect their bodies in relationship to movement in space? Looking at these questions within the context of District Six, the erasure of people from the site can be examined through the lens of mobility. In Michel de Certeau's chapter Walking the City in the "Practice of Everyday Life," he explains the process of walking as an act of agency that inherently defines the space of the city. ${ }^{74}$ People, he demonstrates, create spatial meaning:

Their swarming mass is an innumerable collection of singularities. Their intertwined paths give their shape to spaces. They weave places together. In that respect, pedestrian movements form one of these "real systems who in fact makes up the city." They are not localized; it is rather they that spatialize. ${ }^{75}$

In this sense, de Certeau argues that people are the catalyst for generating meaning in the city through the many subjective ways in which they move and interact with the spaces they inhabit. He argues that the pedestrian "transforms each spatial signifier into something else," thus constantly changing the space and increasing the amount of possible understandings. ${ }^{76}$ 
The subjective act of walking can be viewed as an act of agency in which each individual provides meaning, generating layers of pattern and understanding as well as complexity and contradiction to how the urban space is understood. This constant state of shifting spatial understanding creates a living urban environment which is always in transition.

Looking to District Six, Michel de Certeau's analysis of space can provide insight when understanding how the inhabitants of District Six lost agency as the site was erased and they were removed from the city. De Certeau speaks of each individual as having an 'intertwined path' which 'weaves places together,' almost as if space can be thought of as a series of strings which make up a larger fabric. Through their mobile actions, each individual in District Six contributed to the complexity of the overall fabric, creating and generating meaning. Each resident provided a distinctive understanding of the site through the way they interacted and moved through the space of District Six as each path became imbued with choice, meaning and emotional resonance.
Through choice, individuals were able to make decisions based on why, how, when and with whom they would go to and from different spaces. Within each of these choices, there is also a sense of memory and meaning associated. Some paths may be intertwined with memories of past experiences or importance, or may generate new meanings through happenstance experiences. Similarly, each path becomes tied with emotional significance, invoking an individual experience on the body which is tied to the sound, smell, materiality of the built environment, environmental conditions, person to person interactions and mental state of the individual in that space. Mobility allowed these individuals the agency and power to constantly shape, understand and change the spatial quality of District Six, contributing to its complex and intertwined urban fabric.

As the spaces of District Six were pulled apart string by string through the erasure of the built environment and the forced removal of residents, mobile agency was similarly erased. Routes and paths, inhabitable space and intimate places of interaction, 


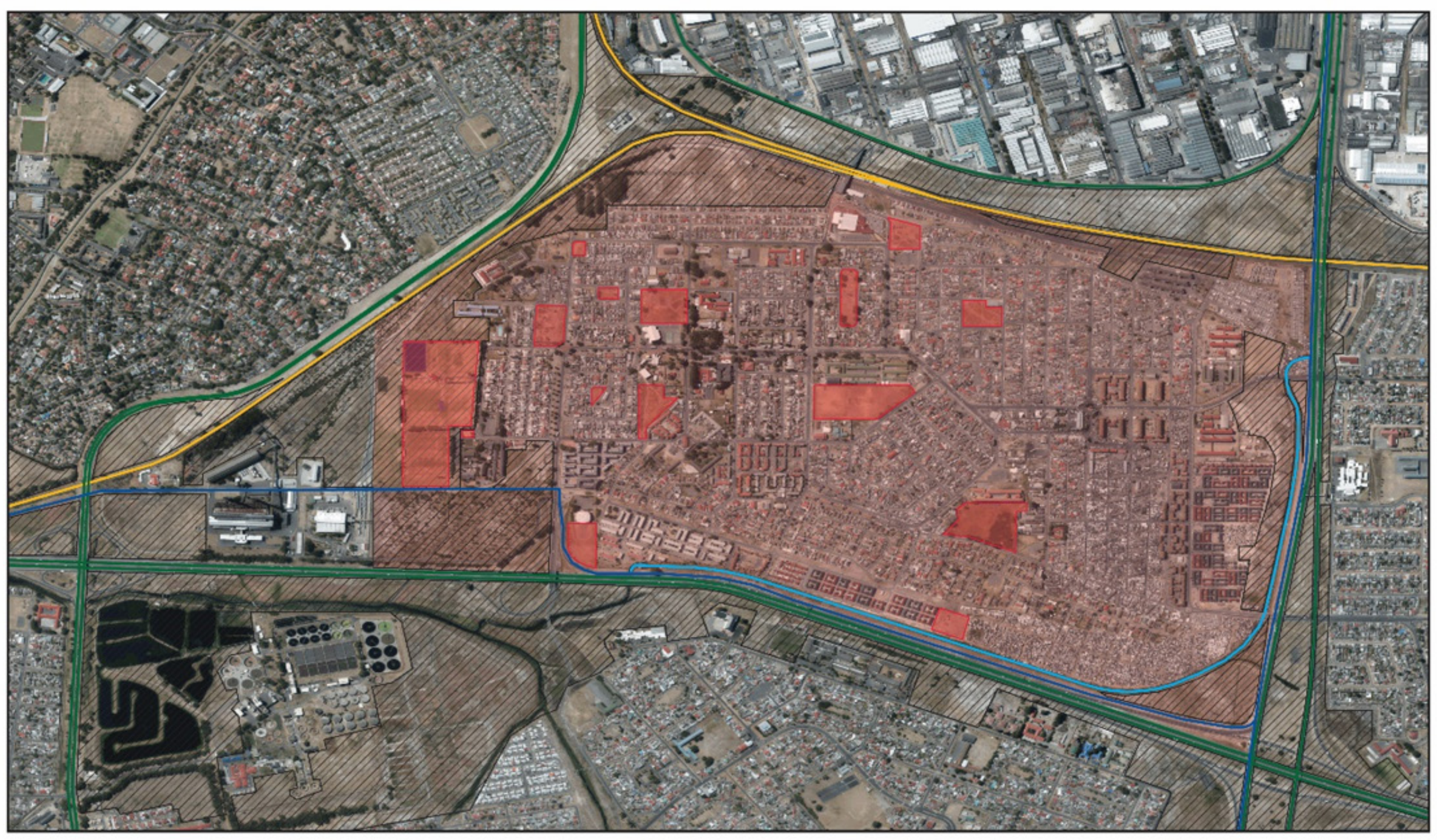

Fig. 22 Langa Township infrastructure map, green (highways), yellow (railway), dark blue (electrical corridor), light blue (water), black line (land buffer), dark red (public space). 
meaning and significance were torn and ripped from the urban fabric of District Six, making it hard to understand, interpret and use space at a human scale. The erasure of people who had the agency and power to understand, shape and change the spatial quality of the site ultimately removed the ability of the space of District Six to retain its previously rich sense of meaning that was fostered through mobile interaction.

The agency of mobility was also a target in the development of the urban planning of infrastructure in the creation of the townships. Looking at the example of Langa Township, it is evident how the infrastructural networks were and continue to be used to divide these sites from one another and ultimately the city center. On the periphery of the site, the train line, highway and land buffer zones wrap the interior community as impermeable boundaries, containing the people to these spaces and alienating them from the other townships. Within the site, wide streets and the radial building patterns of the Garden City Movement's planning strategies create a panoptic effect in which citizens are under continuous control and surveillance.

77 Mobility in relation to the city at large means that people not classified as white were also not allowed to participate in the life of the central city. ${ }^{78}$ Their existence in the city was seen as transitory as they were only allowed into these spaces temporarily for work..$^{79}$ Then and now, the relationship of these bodies to the city center is one in which the act of travelling to and from the city is a daily re-enactment of the forced removals, and one which reinforces their lack of claim to its land. To this day, many past residents of District Six remain in the townships with the agency of mobility denied to them. They are not able to become strings in creating the complex urban fabric of the city due to their mobile alienation. The spatial politics of apartheid remain, creating physical, social and economic boundaries which remove their ability and choice to move through the city. As a result, they are not able to participate in creating a city fabric that reflects their identities, histories, understandings and claim to the space within it. 


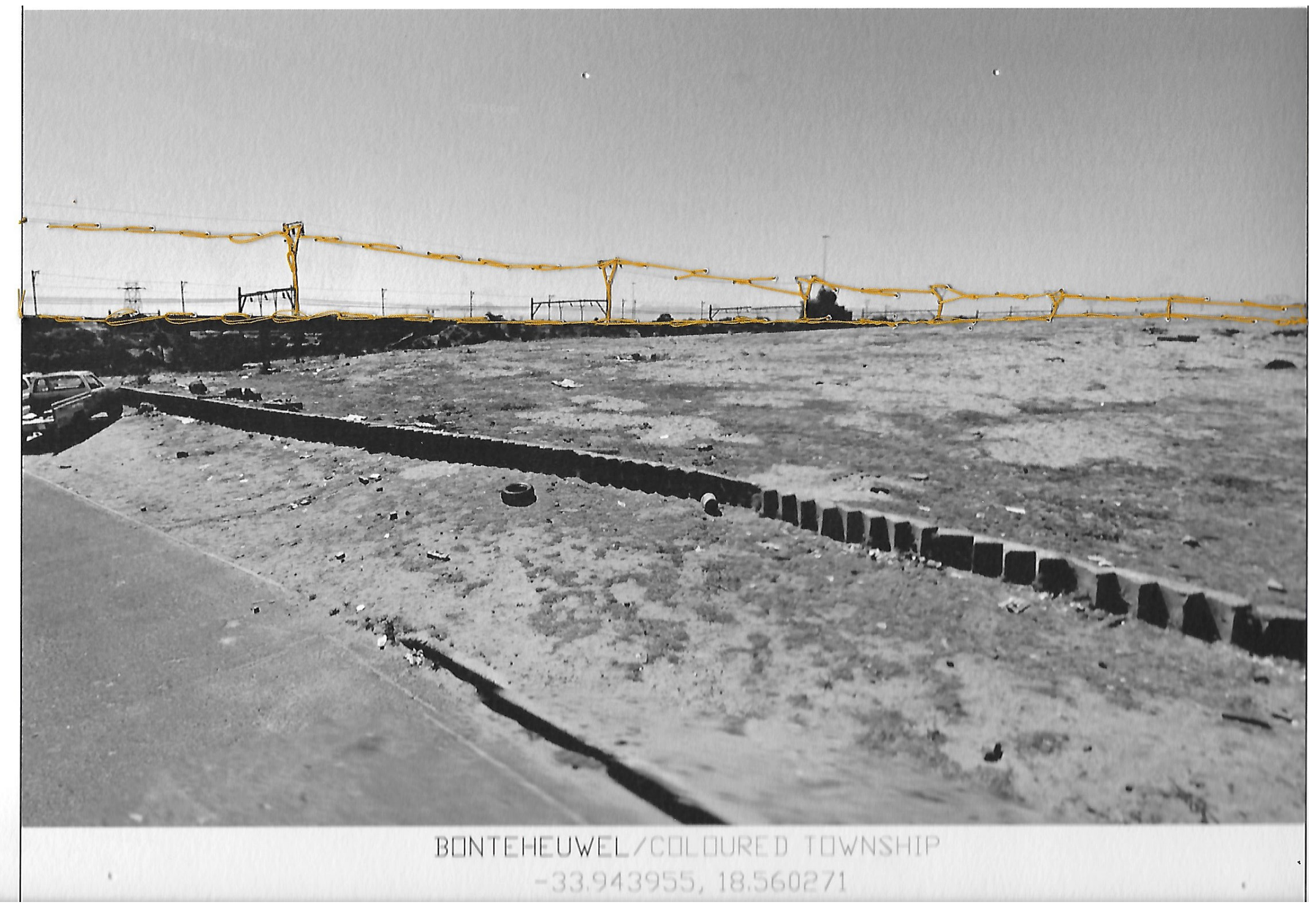

Fig. 23 Stitching with orange thread the existing train infrastructure of Bonteheuwel Township. 


\section{The Erasure of Voice}

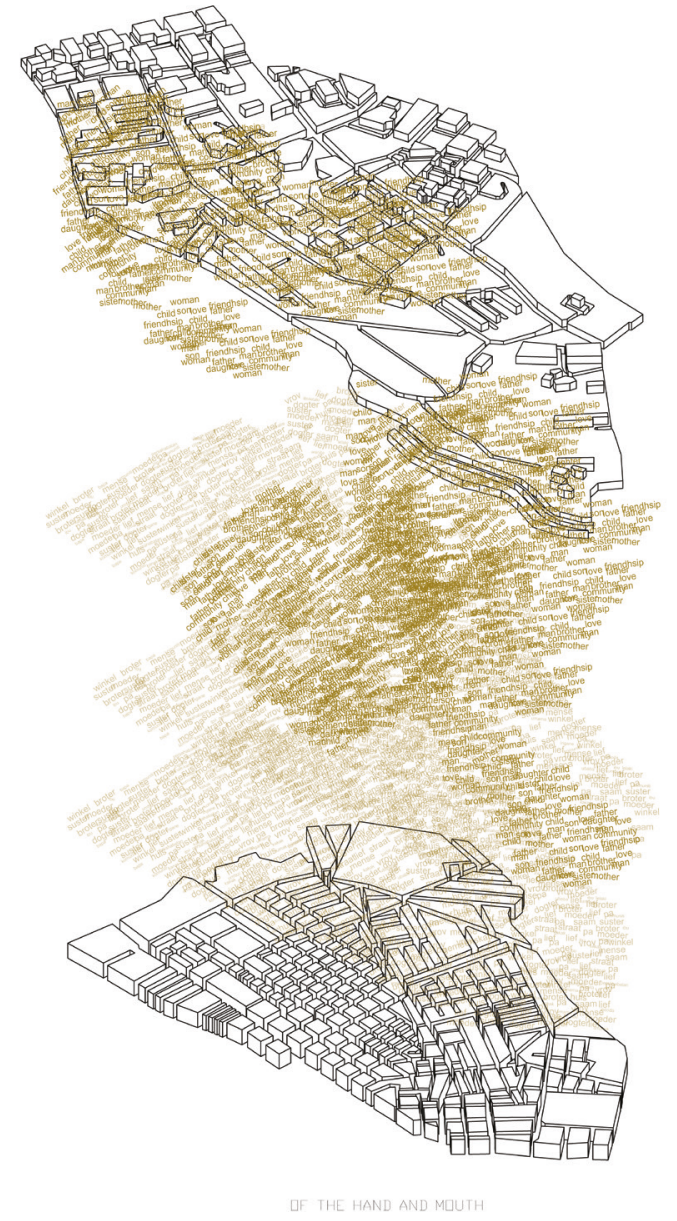

Fig. 24 Conceptual representation of the erasure of 'voice.'
What kind of understanding does language provide about space? How can it give people agency within the urban environment? Within the context of District Six, language becomes a focus with which to recover and reconstruct the existence of the voices of the people. In Italo Calvino's "Invisible Cities," he brings forth the importance of language in his description of fifty-five fictitious cities and correspondence between the Emperor Kublai Khan and the explorer Marco Polo. For Calvino, language is a tool in which space and objects can take on various meanings. ${ }^{80}$ Marco Polo's descriptions of places helps Kublai Khan to imagine these spaces and how he might inhabit or move within them. ${ }^{81}$ Through the description of these places and objects, they begin to take on so much meaning that just by viewing the objects, Kublai Khan is able to understand their inherent associations. ${ }^{82}$ Furthermore, Calvino speaks again to the significance of language in describing the complexity of memories related to space in his description of the city of 'Euphemia'. 83 He writes: 
The others tell, each one, his tale of wolves, sisters, treasures, scabies, lovers, battles. And you know that in the long journey ahead of you, when to keep awake against the camel's swaying or the junk's rocking, you start summoning up your memories one by one, your wolf will become another wolf, your sister a different sister, your battle other battles, on your return from Euphemia, the city where memory is traded at every solstice and at every equinox. ${ }^{84}$

Through this description, Calvino remarks on the complexities of space as his understanding of 'Euphemia' and his journey changes due to multiple shared understandings and experiences of the city. By doing so, Calvino points out that cities take on layered and alternative meaning through the exchange of experiences.

Before the erasure of District Six, the agency of voice provided a complex and layered understanding of the site. Residents were able to converse and engage in conversation in daily life, sharing experiences, stories, language and music when coming together for public events, social gatherings and more intimate get togethers with friends and family. Through these exchanges, residents shared memories, history, culture and knowledge which helped to create and form their identities, as well as shape the identities of others. This sharing of voice created a sense of community, one with both a common and varied understanding of the site of District Six, creating a complex urban fabric. The physical state of voice was also present in many forms on the site, including street signs, advertisements, store fronts and written word. The forced removal of people from District Six erased the possibilities for the exchange of voice as the community was broken apart at every scale. From the more holistic view of the entire community, to neighborhoods, homes, friends and even families, the erasure of the site fragmented and tore apart the many voices which made up its multilayered fabric. By eliminating the many spoken and physical traces of voice on the site, District Six began to singularly reflect the voice of the apartheid government.

No longer tied to the physical landscape, the landscape of the mind became an important way in 


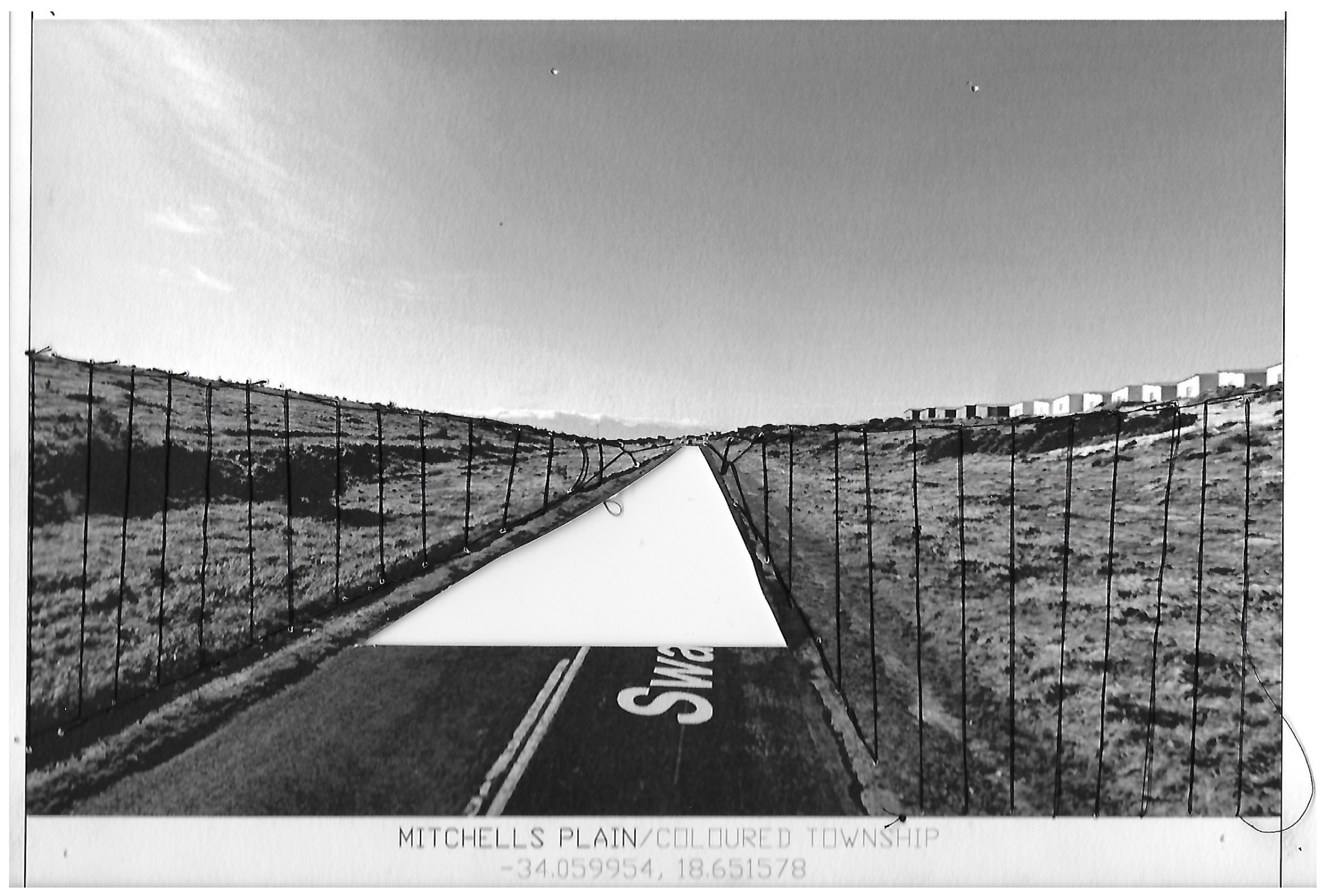

Fig. 25 Stitching with black thread the existing land buffers of Mitchells Plain Township. 
which to reconstruct an image of space, land, history and identity. ${ }^{85}$ By doing so, the land could be recovered through the imagination, conflicting with the outside, physical reality of the landscape. ${ }^{86}$ To combat this alternative understanding of the land, the apartheid government took three approaches. Firstly, they began to target empty space as it had the potential to be politicized, as text, memory and speech could be linked to spaces that were erased. ${ }^{87}$ Instead, they began building on the land, rendering these parts of the city invisible, severing the imagination, memories and possibilities expressed by the original residents. ${ }^{88}$ Secondly, the apartheid government targeted language through active legislation. ${ }^{89}$ Publications which opposed the National Party were censored, while individual movement, writing, speech, political activity and personal associations were restricted. ${ }^{90}$ For example, blank spaces within the printed pages of the newspapers began to appear, representing not only the absence of speech, but the removal of it. ${ }^{91}$ Lastly, the racial division and fragmentation of people to different townships prevented the evicted residents from coming together to share and form a collective memory and vision for the future of District Six.

Present day, voice is still an agency which many residents in the townships are not able to exercise. Many townships remain fragmented and without a unified community to express their history, memories and desires for the future. Space and representation continue to be an issue as much of the township urban fabric is a reflection of both apartheid spatial planning, which excluded and discouraged residents from forming a community, and poor infrastructure which does not provide the necessary spaces for people to come together to share memories, history and knowledge. 


\section{The Erasure of View}

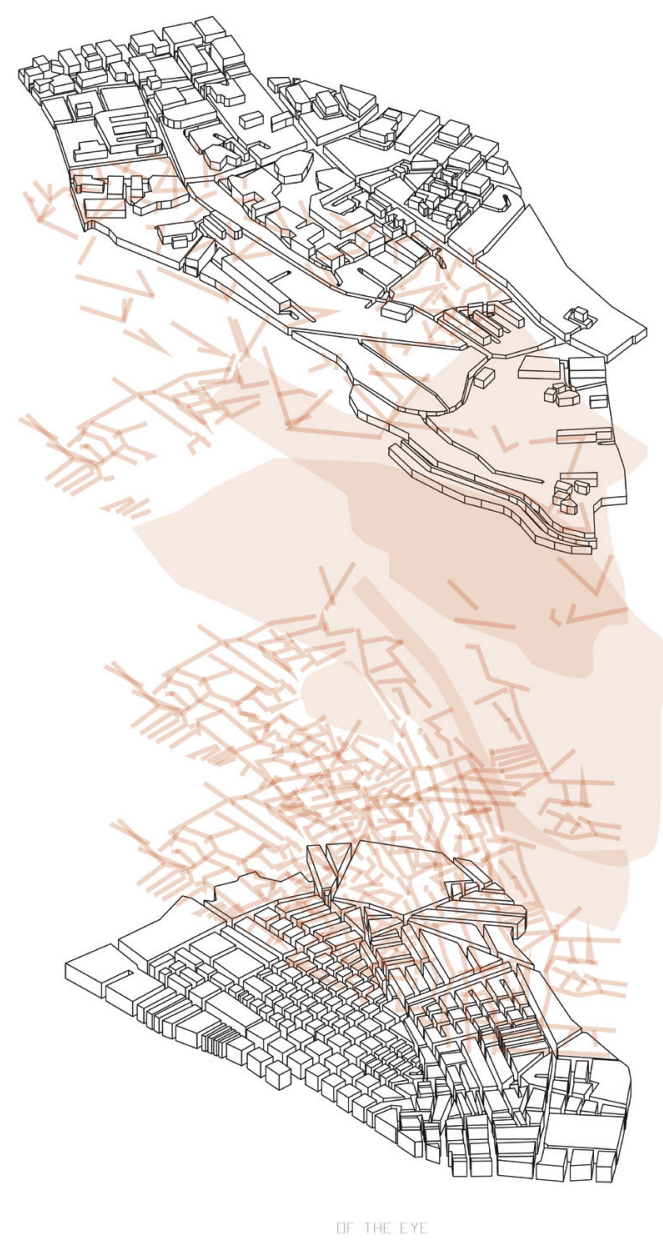

Fig. 26 Conceptual representation of the erasure of 'view.'
How does the erasure of view affect an individual's understanding of self? What kind of agency do forms of representation such as the photograph provide in the absence of spatial evidence? In the 1970's, during the beginning of the forced removals and demolitions, the South African photographer Jansje Wissema began to photograph the people and spaces of District Six. The photographs provide a view into the daily life of these people, documenting the unique conditions of the space. These photographs serve as a tool with which to examine the agency of 'view.'

In Susan Sontag's chapter 'In Plato's Cave' from her book "On Photography," she argues that photographs serve as both evidence and a record of something that happened, acting as a tool of anxiety of absence and disappearance. ${ }^{92}$ Photographs provide proof of something that existed. ${ }^{93}$ They claim possession of a space. ${ }^{94}$ More than evidence, they create specific views of the world which turn experience into a way of seeing, understanding and knowing a place. ${ }^{95}$ Jansje Wissema's photographs of District Six provide a record and 

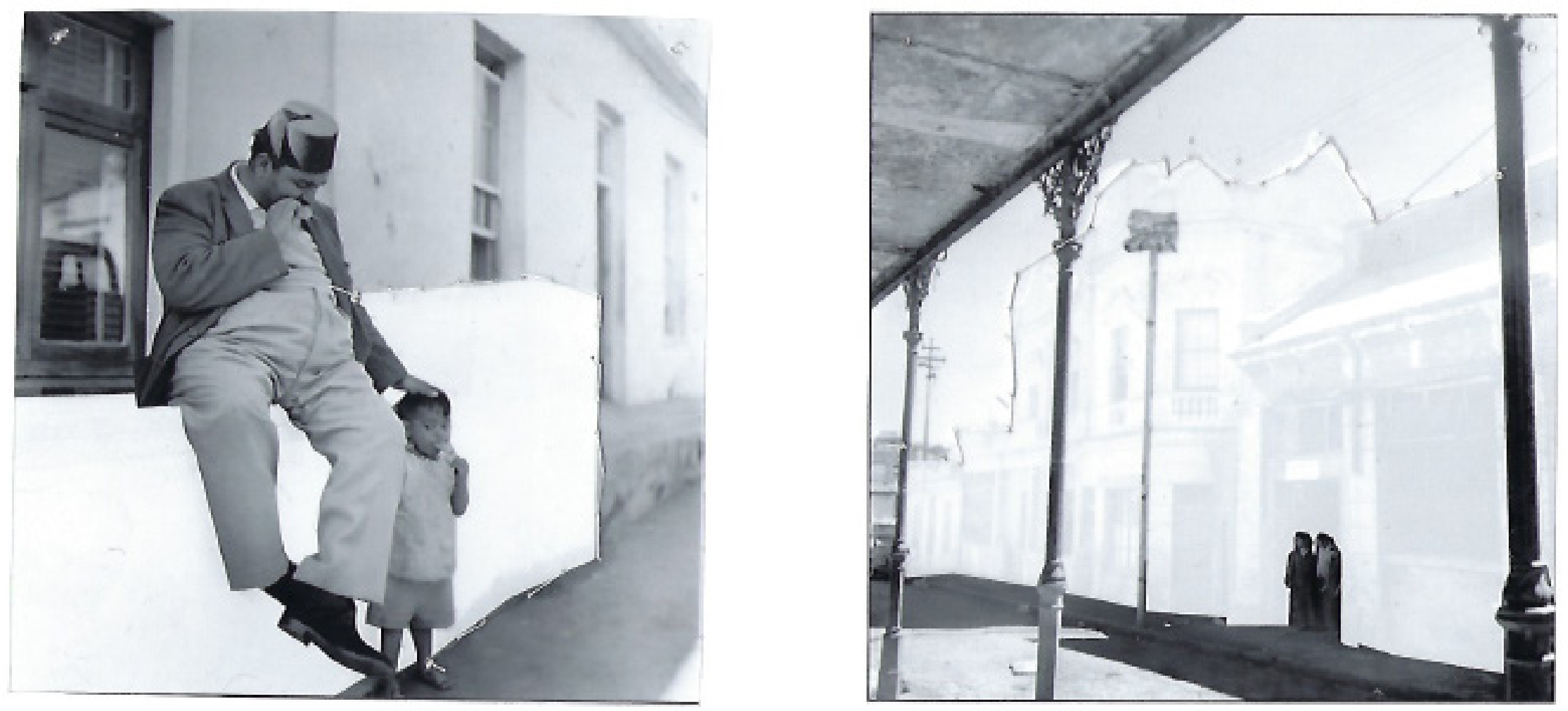

Fig. 27 The erased and stitched photos posit conditions that were lost during the forced removals and erasure of the site. 
evidence of the way of life and the spatial quality of the area. They are proof of the existence of people in these spaces, their specific use of these spaces and their claim to them. In the context of erasure, they provide an alternative understanding and another layer of 'knowing' the urban environment of District Six. environment of District Six.

These spaces, such as the ones in Jansje Wissema's photos, provide a glimpse into the agency of view. In this context, the term 'view' can be understood as the physical characteristics of the environment, whether natural or human-made, which form an understanding of a particular space. Jansje Wissema's photos give context, showing the types and qualities of spaces experienced by the residents of District Six and how they were used. Included in these images are family homes, roads and sidewalks, store fronts, schools, medical centers, public spaces, churches, people and animals and glimpses into the surrounding landscape of Cape Town and Table Mountain. These photos give proof to a way of life that existed, depicting the residents of District Six and how they viewed these spaces.

In Trevor Paglen's Experimental Geography: From Cultural Production to the Production of Space, he argues that though space is something we produce and inhabit, it is also something that factors into our production, conception and expression of self. ${ }^{96}$ Jansje Wissema's photos help to distill this idea, showing how the physical characteristics of the space of District Six were both defined by its residents and in turn, influenced the identities of the residents. By exercising the agency of view, residents could define their physical environment, using specific forms, marks, characteristics or symbols of their culture and way of life. Similarly, through the physical use of space, residents were able to connote specific meanings, creating a complex urban fabric and community framework.

For the residents of District Six, the erasure of the space they once knew not only eliminated their ability to create spatial meaning through the agency of view, but also contributed to their loss of identity. With the 
removal of the residents to the townships, the loss of familiar landscapes of vision that were bound up with the identity of the community were severed, as access to businesses, schools and other amenities within closer proximity to the city were no longer available or no longer existed. ${ }^{97}$ All new representations of the landscape were meant to feel barren and infertile, giving a sense of homelessness. ${ }^{98}$

Moreover, the new settlements were built to contradict the existing landscapes these residents once knew as they were depicted as negative or inverse to the spatial and cultural complexity of the previous community, creating a hierarchy of monotony ${ }^{99}$ Within many of the townships today, the urban fabric for the most part is not defined by and does not reflect the view of the residents of the townships. Within these spaces, residents lack the resources and infrastructure to create and visualize a space and community that is a reflection and representation of themselves. 


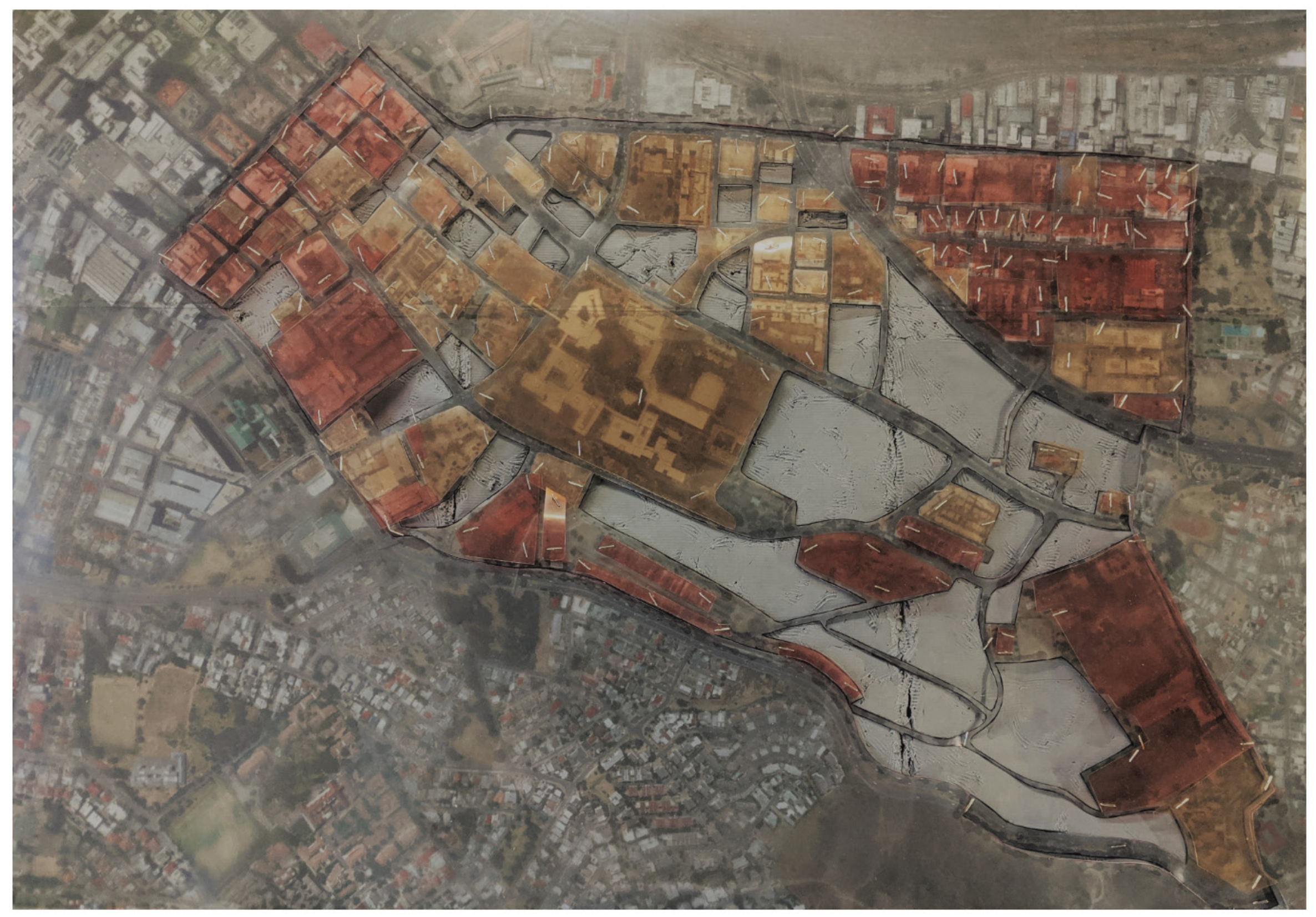

Fig. 28 Original District Six site model depicting barren areas in grey clay, demolished and built on areas (yellow) and untouched areas (red). 

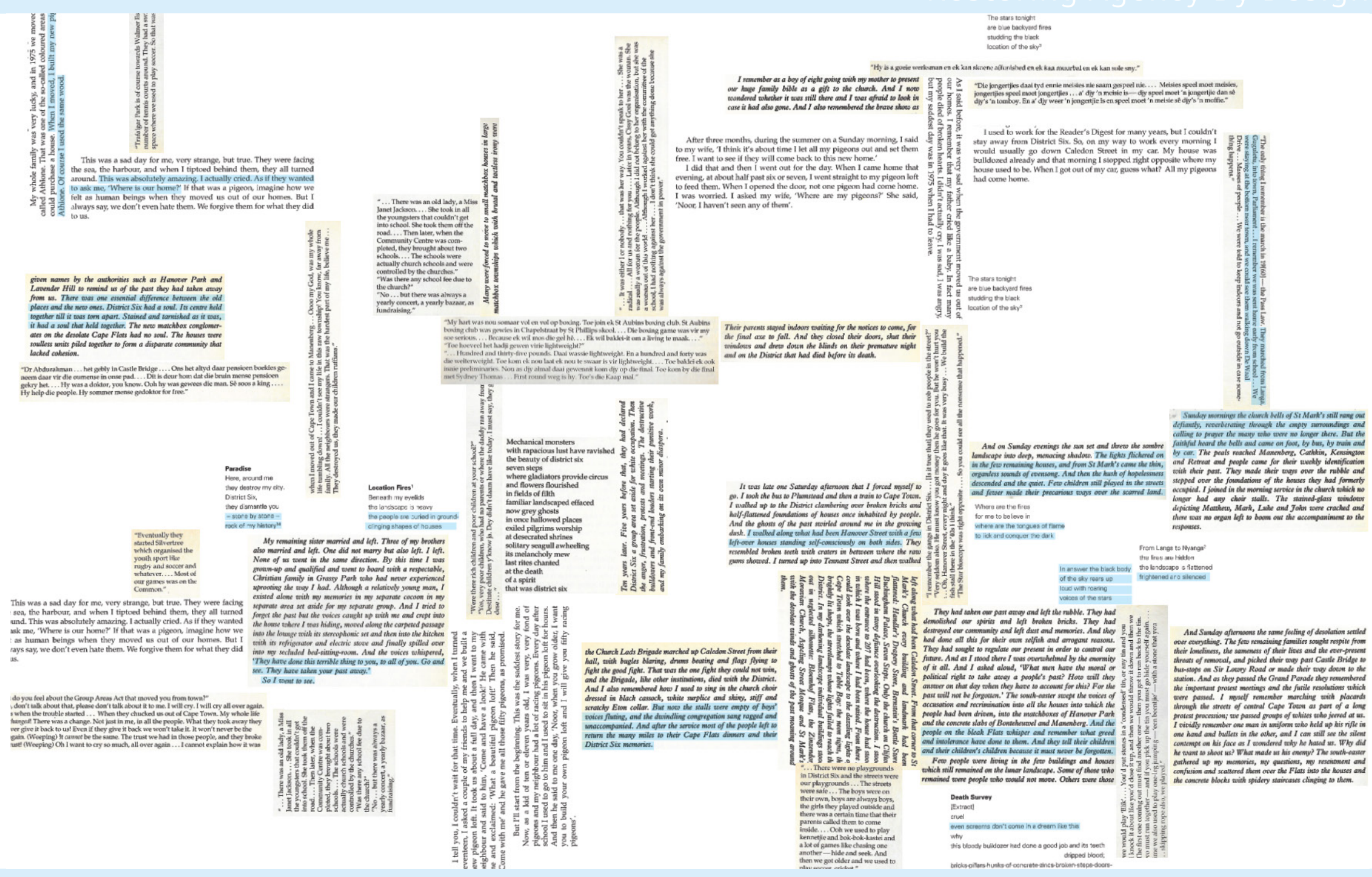

Fig. 29 Compiled voices of the former residents of Distict Six. 


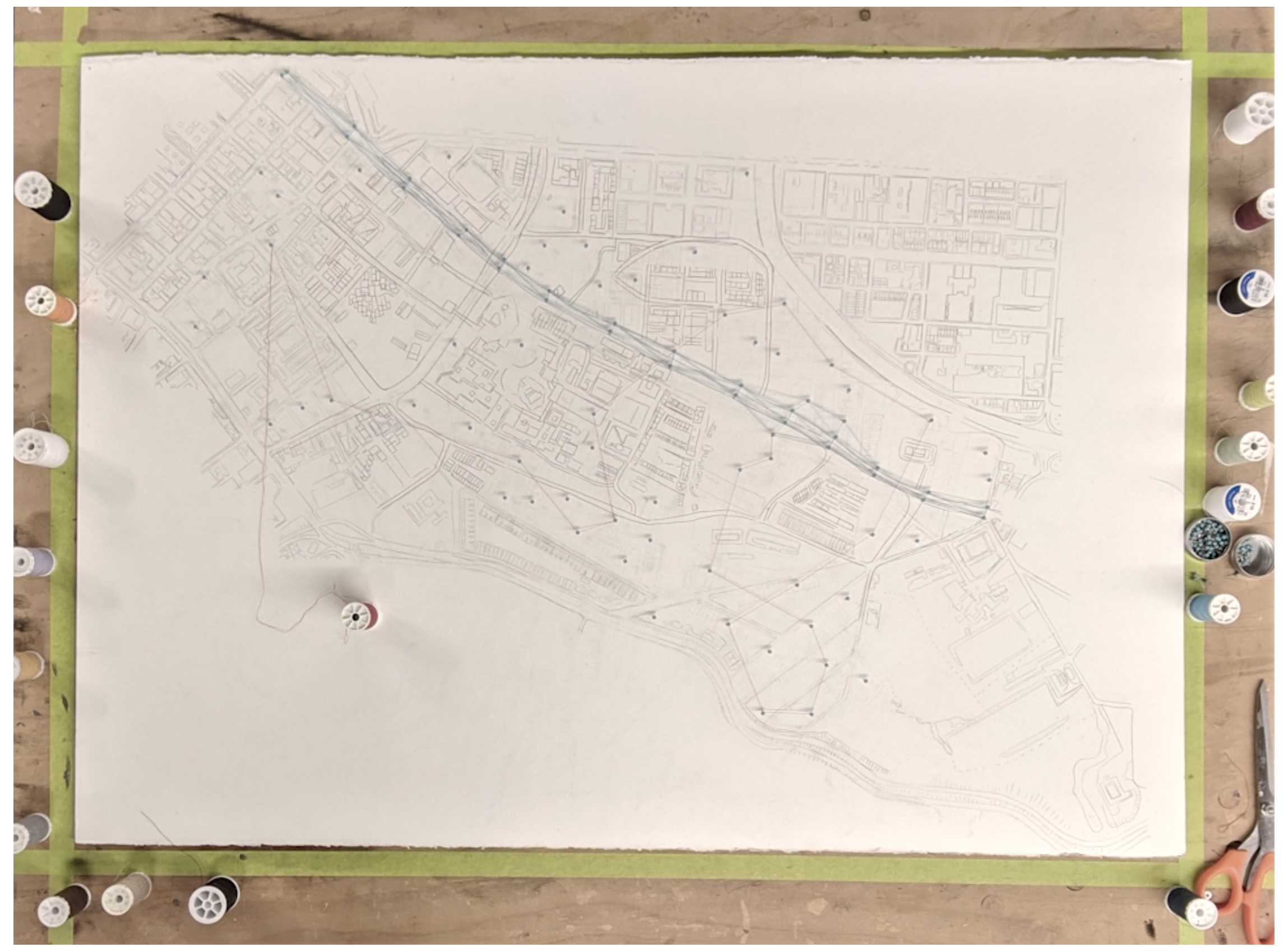

Fig. 30 Video Still, restoring agency on the original site of District Six. Please watch: https://www.youtube.com/watch?v=1Bkt8 9r Io 
The District Six Museum

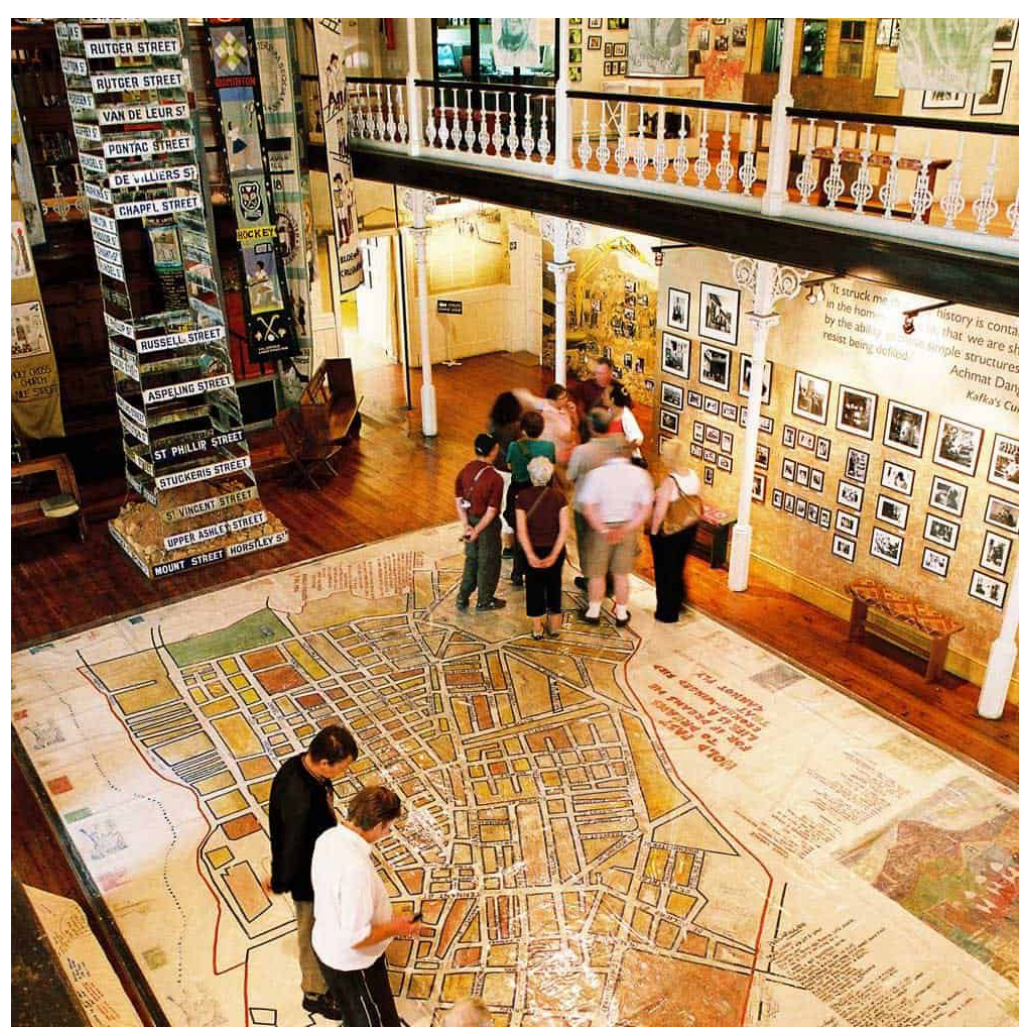

Fig. 31 Inside the District Six Museum. https://www.districtsix.co.za/
Formed in 1994, the District Six Museum was created to mobilize the masses of ex-residents and their descendants into a movement of land restitution, community development and political consciousness. ${ }^{100}$ The museum has become a place for the recovery and reconstruction of the social and historical existence of District Six through the voices of the people. ${ }^{101}$ Through the collection of memories in multiple forms including inscribed maps, photographs, street signs, written texts, oral memories, video, tapestries, quotes, public events and tours of the museum and site, the museum itself has become a catalyst for inscribing meaning, understanding and knowledge of the erased site. The approach of active remembrance sets the museum apart as a way to question the way in which knowledge is formed. ${ }^{102}$ By doing so, the museum and the site itself portray memory as not anchored in a nostalgic past, but rather, as sharpening insights and informing arguments on current social issues. ${ }^{103}$

The approach of active remembrance in which the District Six Museum operates provides important insight 
into the way in which this architectural project might begin to engage with the legacy and memory of District Six. Similar to the role of the museum, architecture has the potential to act as a catalyst in which to further understand these layered physical realities with multiple histories, representations, imagined landscapes, traces, memory and possible future narratives.

\section{Restoring Agency By Design}

This architectural proposal set out to make visible and empower the residents of the townships to restore the three agencies of mobility, voice and view by introducing a set of dynamic elements, each connected in some way to a network of regional train lines. This transit infrastructure restores the agency of mobility, but it also supports several other elements that help to restore agencies of view and voice. The train stations as re-envisioned township cultural centers serve as meeting places for conversation, counselling and education. The train cars themselves are both a mobile vessel and low-rent facility for offices, public services and vendors. From the cars, elevated above the ground, vistas of a changing landscape are open to view.

The three agencies are further unified through an evolving tapestry that is continuously generated by data from the residents of each township above the train stations. In this process, the train car acts as a data collection tool, using WIFI to download data from station to station. People riding the trains, and those from the community, volunteer personal messages and observations, news and images. Giant sewing needles occupy the landscape, surrogate weavers that translate these messages into a canopy of colourful, woven threads.

On the original site of District Six, a station on the historical and central Hanover Street provides a singular destination for these threads from the townships. The canopy that forms over this former vibrant neighbourhood, so aggressively erased through apartheid, becomes a blueprint for a new ground-scape on the original site. 
The entire dynamic infrastructure, with its myriad elements, challenges physical realities, histories, traces, memories and limitations of the existing urban landscape. As a catalyst that transverses space above the ground, the canopy is not limited to the boundaries that determine land ownership, or jurisdictional authorities that were shaped by the apartheid regime. While the existing infrastructures have worked to control, divide, limit and imprison the people in their townships, the train's ecosystem establishes a new layer of interpretation of the landscape. It is both counterpoint and antidote to the repressive conditions on the ground, while simultaneously positing new narratives of connection, empowerment, and creativity.

\section{The Train}

The creation of a new elevated train line was chosen as a point of architectural focus because of its potential to challenge the physical realities, histories, traces, memories and limitations of the existing urban landscape. As a catalyst that transverses space above the landscape, it is not limited to the same physical boundaries of the land below that was shaped by the apartheid regime. These existing infrastructures have worked to control, divide, limit and imprison the people of the townships. By being elevated, the train instead works to create a new layer of interpretation of the landscape, challenging these existing conditions while simultaneously positing new future understandings and narratives. Furthermore, because the train is raised, its visibility acts as a symbol of the people and townships as a connected and fundamental part of the city fabric. Traditionally, on grade trains have created another physical barrier that separates people from one another. By raising the train line, new weaving opportunities are possible in the public realm.

The train is also the most economical form of transportation as it has the potential to service the largest number of people. By using a train with its multiple large cars, there is a greater possibility for various programs, uses and the interaction of people, reinforcing and creating a sense of community. Safety 
has also continued to be a transportation concern in Cape Town. By including program on the train, there will always be people present to monitor, regulate and reinforce rules and appropriate behaviors in order to serve the best interests of the community.

\section{Palimpsest and Acupuncture}

William Kentridge is a South African artist who creates charcoal drawings, animations, video installations, shadow plays, mechanical puppets, tapestries, sculptures, live performance pieces and operas centered around his place as a white South African within the violent oppression, class struggle and social and political hierarchies of the apartheid and post-apartheid eras. His work serves as a precedent for both understanding and representing the complex history and future narratives of District Six.

In his work, Kentridge continually uses the artistic device of 'palimpsest' in which he erases, layers and recreates images to speak to the many layers of voices, history and understanding present in his art. Palimpsest provides a framework from which knowledge is constructed rather than received, understanding the world as a place meant to be understood as a process rather than a fact. ${ }^{104}$ William Kentridge's notion of palimpsest provides a framework for this thesis. Through a similar process of using erasure, layering and recreation, multiple understandings of District Six can be posited.

The medical practice of 'acupuncture' also provides another precedent for thinking about District Six. Acupuncture can be defined as "a system of integrative medicine that involves pricking the skin or tissue with needles, used to alleviate pain and treat various physical, mental and emotional conditions. ${ }^{105}$ The act of acupuncture connotes ideas of the pin as a catalyst in alleviating pain and the creation of a more positive bodily condition. When thinking about acupuncture in the context of District Six, the landscape can be reinterpreted as body. The ground similarly exhibits sites and conditions of pain and can be thought of as a 
skin with multiple layers, scars and connected systems.

As in acupuncture, the pin inserts itself to alleviate the pain present in the landscape. 


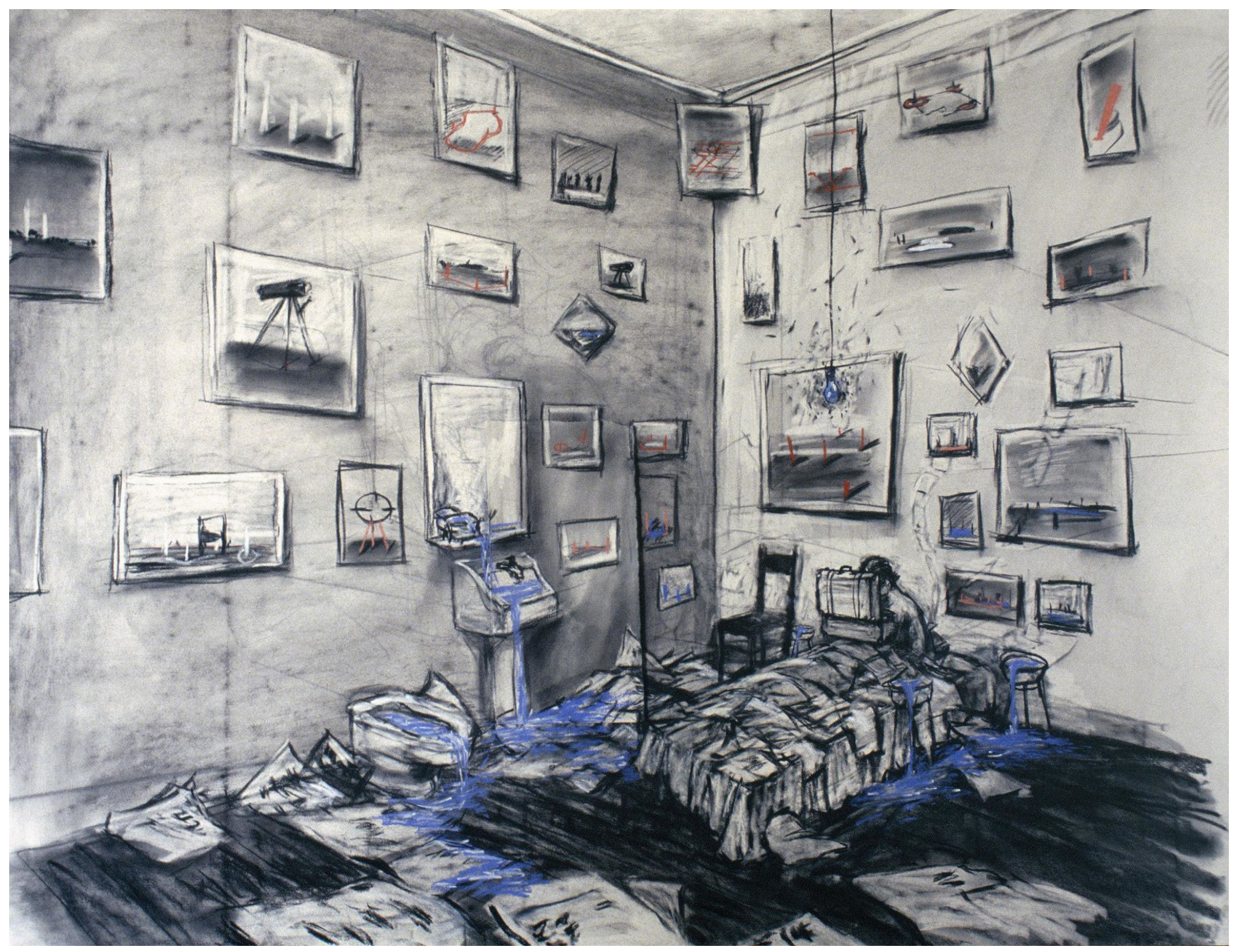

Fig. 32 William Kentridge, Felix in Exile, 1994 https://www.moma.org/audio/playlist/1/248 


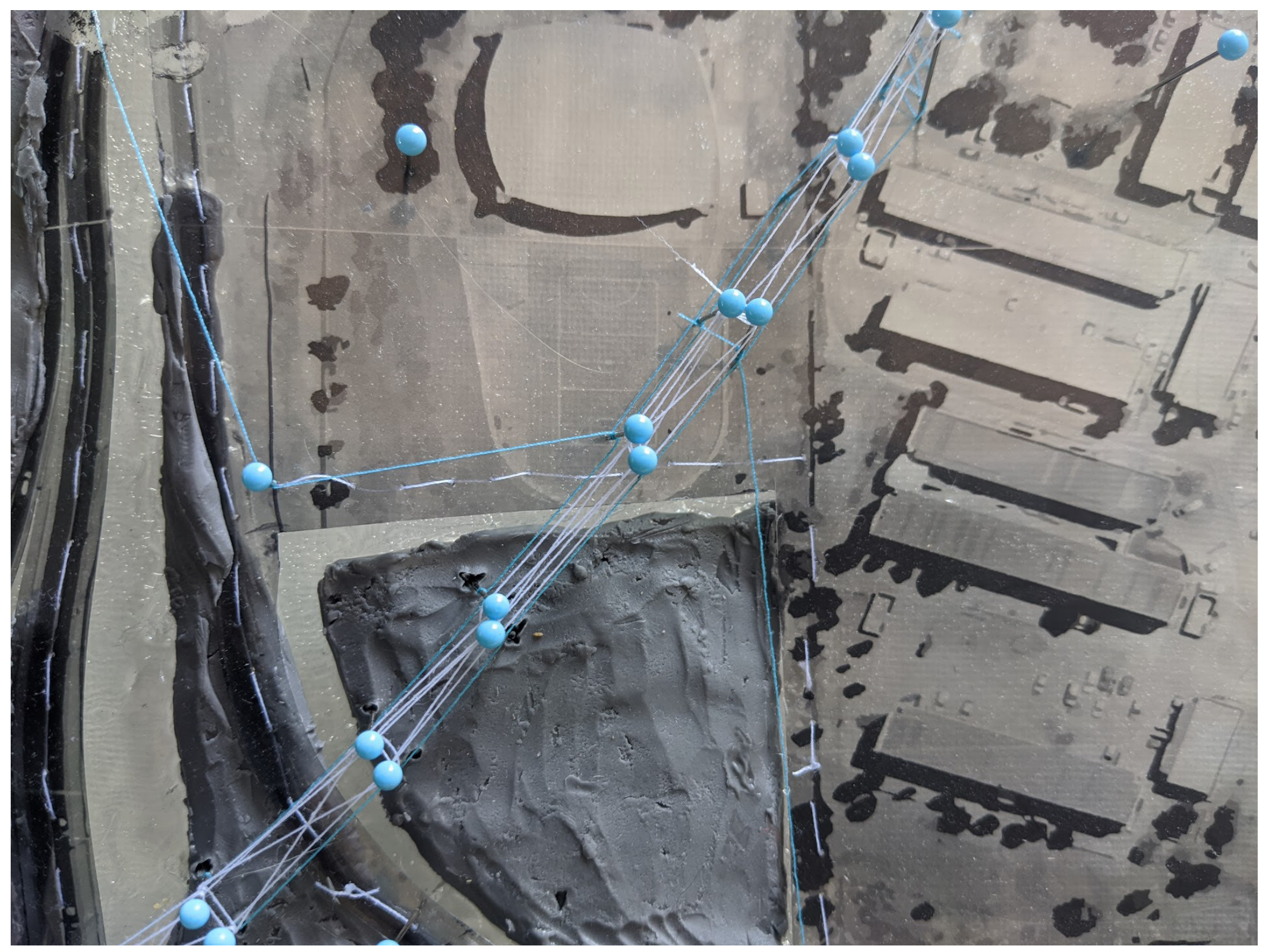

Fig. 33 Experiments with palimpsest and acupuncture in the landscape of Langa Township. 


\author{
Death Survey \\ [Extract] \\ cruel \\ even screams don't come in a dream like this \\ why
}

this bloody bulldozer had done a good job and its teeth dripped blood;

bricks-pillars-hunks-of-concrete-zincs-broken-steps-doorsbroken-glasses-crooked window-panes-broken-flowerpots-planks-twisted-shoes

lay all over the show

like a complete story.

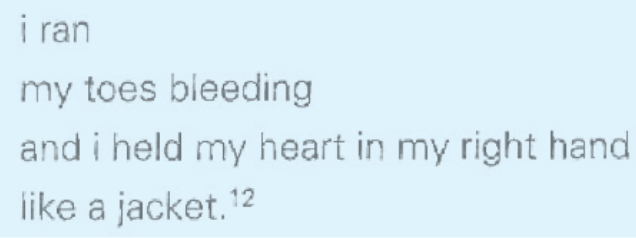

-Mongane wally serote 


\section{Restoring Mobility}

To restore the agency of mobility, this project features an above ground train line at the urban scale of the city, extending from District Six to the townships. The train line acts as a suturing device, by stitching a new, visible path atop the landscape which defies the current existing physical conditions of the urban environment such as the infrastructures of the ground level train, roads and highways, land buffer zones and town planning strategies. While these existing ground-level infrastructures have largely wrapped the townships, creating physical, economic and social barriers to mobility, the new, above ground line instead cuts across these existing conditions into the townships. By doing so, the new line challenges the current hierarchy and power imbalance in the urban landscape by connecting these residents as visible, equal and vital participants in the creation of the city fabric. Through this notion, the train line acts as a catalyst to give residents the choice and opportunity to redefine various spaces in the city, creating an urban environment which better reflects their histories, memories, culture and desires for the future.

Though the new train line is an above ground architectural catalyst, it also works to disrupt the physical experience of the existing ground level conditions. Because the above ground train line is meant to contradict and cut across the existing landscape, it draws attention to these existing conditions. As the train line passes over existing infrastructure in the city such as a road or highway that previously served to isolate part of the urban fabric, it creates a new material condition on the surface of the ground. This alteration is created by cutting into the existing landscape, and replacing it with a new material which creates a visual, sonic and physical impact on those come into contact with it both visually and sensorily. By doing so, the above ground train line draws attention to and posits a new understanding of the urban environment by questioning why these ground conditions exist as they do. It also suggests that the environment can be seen, 


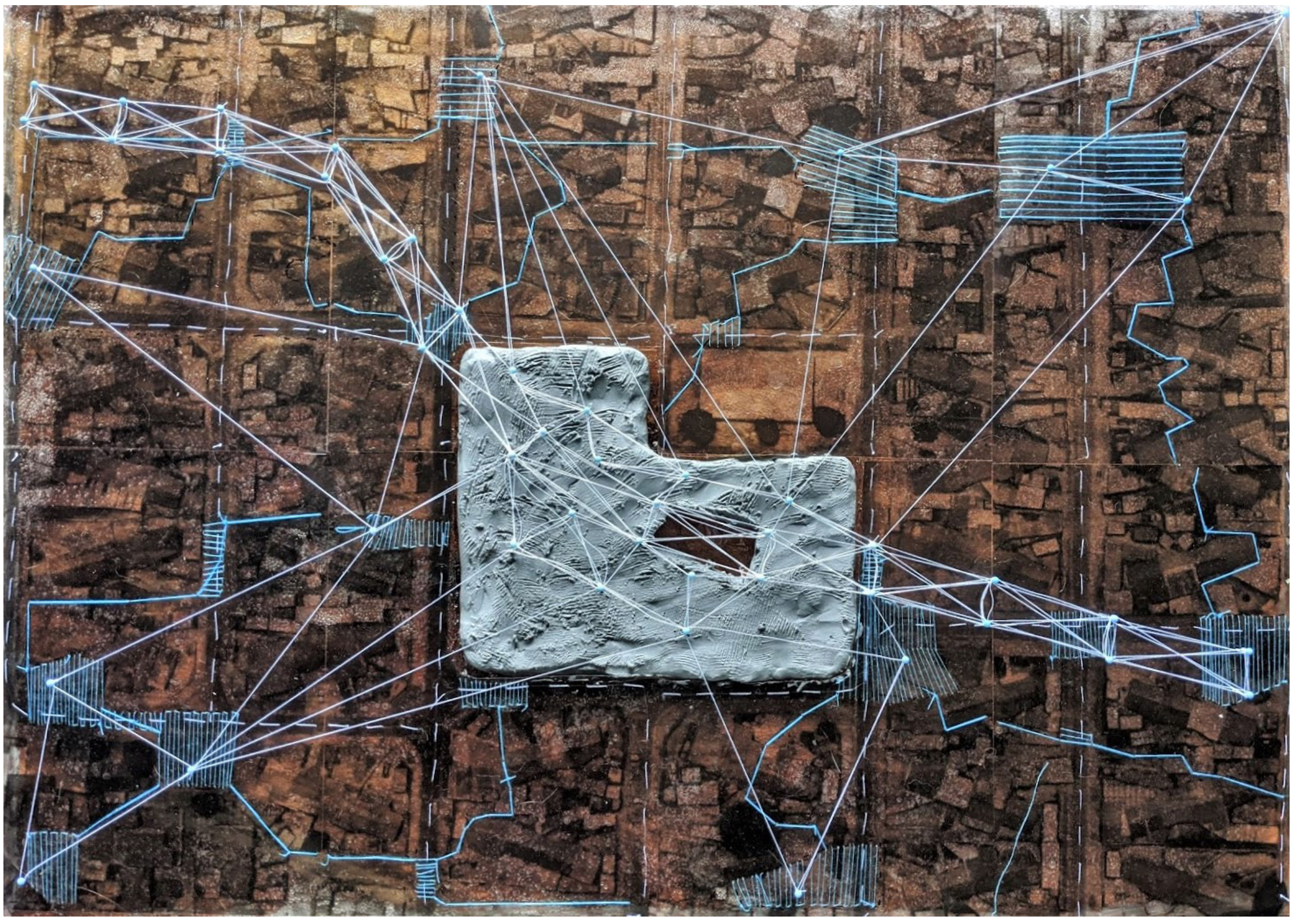

Fig. 35 Conceptual physical model depicting the train line through the use of wood, gel wax, printed acetate, clay, sewing pins and thread. 


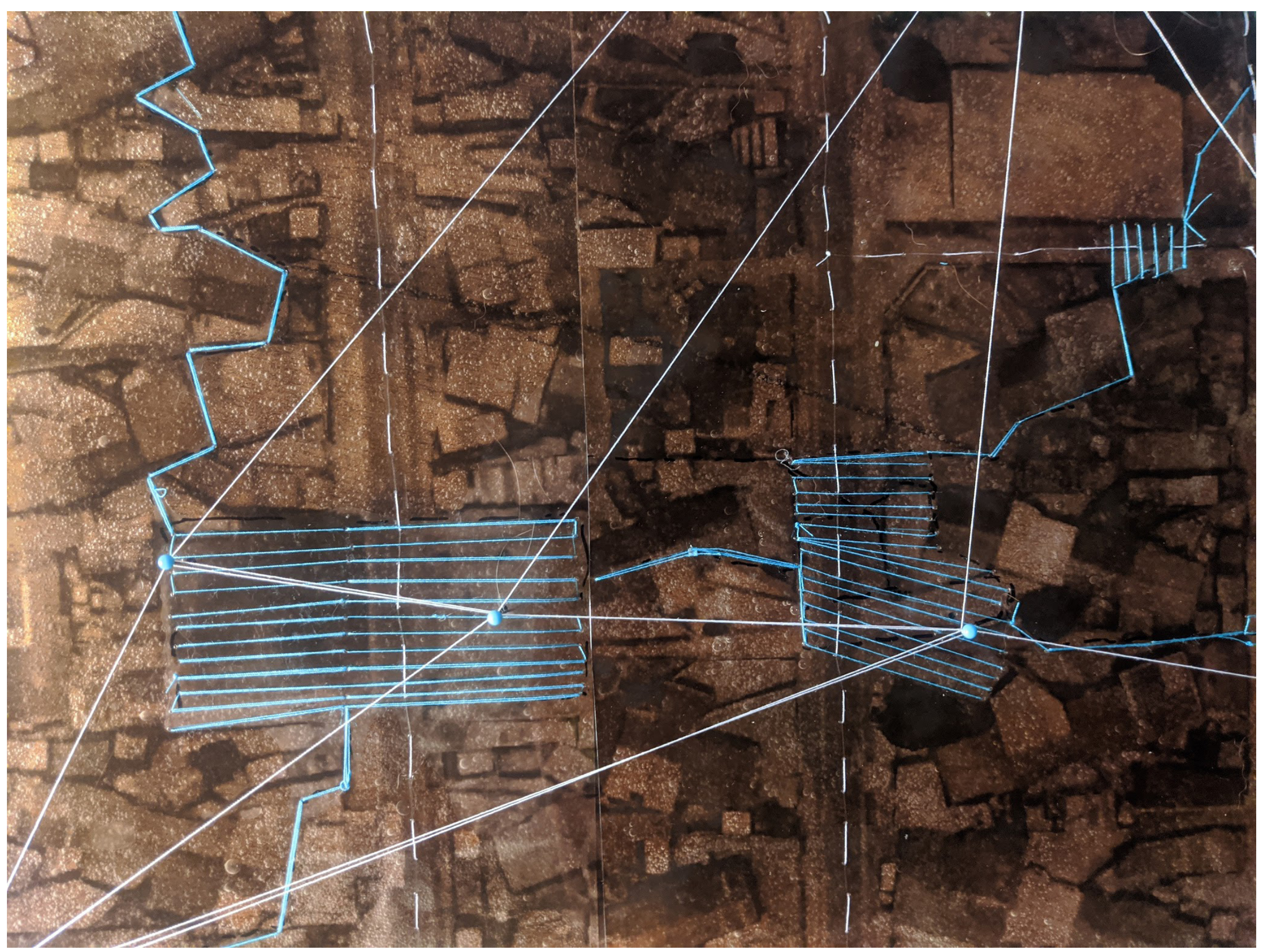

Fig. 36 Threads are stitched to represent the activated spaces and connecting pathways around the needles. The activated zones affect and contradict the existing logic of the urban environement. 


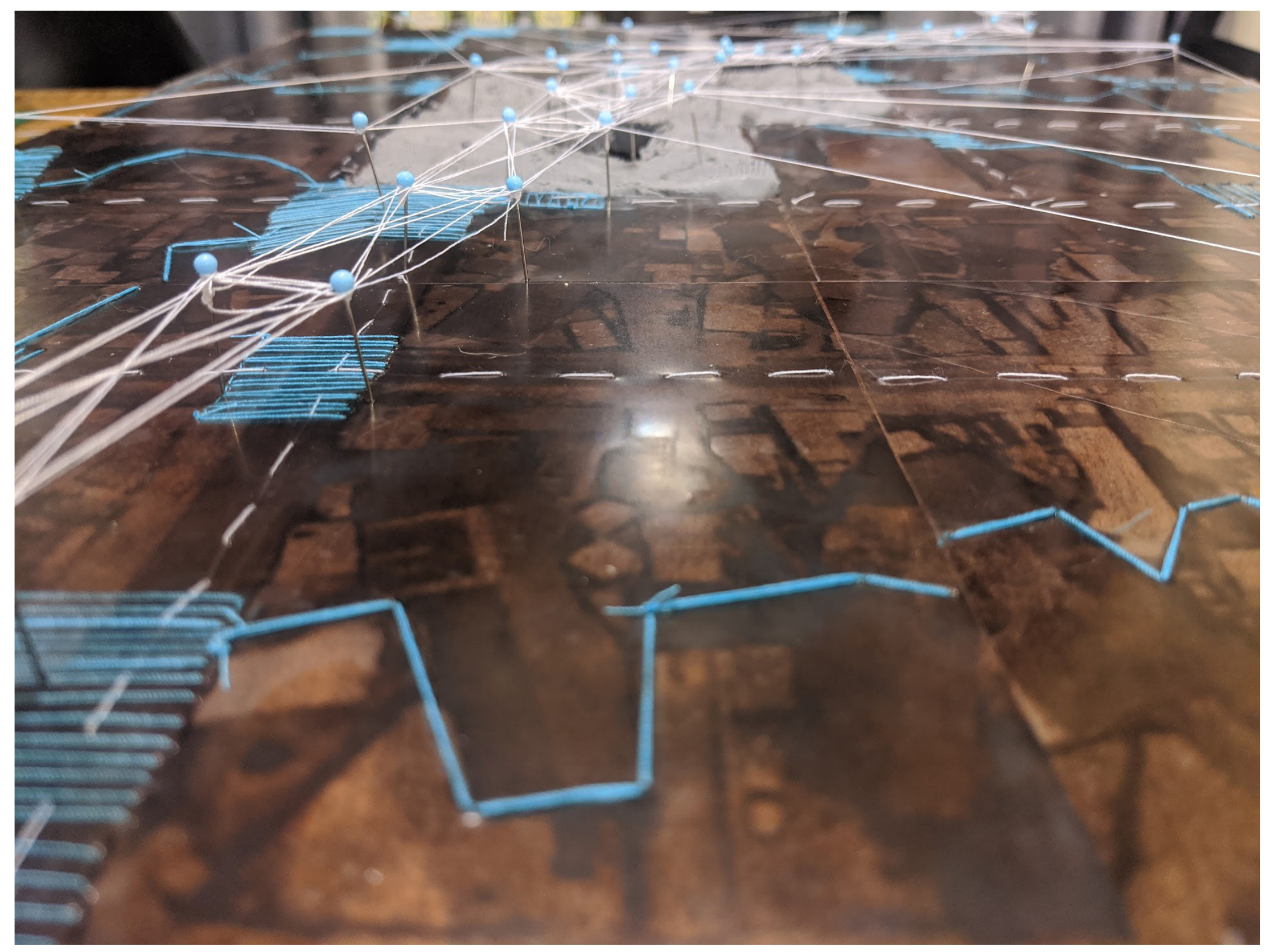

Fig. 37 The train line as depicted by threads and acupuncture points in the landscape. 
experienced and moved through by many types of people in various ways.

As the above ground train line moves into the townships it creates an active dialogue with the ground condition through a series of intensified acupuncture 'needles.' These needles exist as both structural elements of the main train line and as infrastructural points in the landscape. The needles engage the township residents, creating spaces of mobility, opportunity and appropriation, and therefore act as architectural catalysts. For example, the needles work to collect water and generate electricity as well as provide a community amenity for public space and gardens, giving the residents an infrastructural framework. Each activation point is also connected via a small canal system which, similar to the train line, cuts through the landscape creating new paths and material conditions, contradicting and positing new understandings of the existing environment. Through these architectural catalysts, the residents are then able to adapt and shape the spaces, and begin to frame and choose how they move and connect within them. This condition creates a space that is always in constant transition as it can be shaped at will according to the personal need, meaning or emotional drive of the individual residents. By instilling the agency of mobility, choice and interaction, the urban environment becomes a more complex space of engagement, designed with a sense of conditioned openness-a type of interactive space with a designed framework. The result is an augmented urban fabric which greater represents and is produced by the residents. 


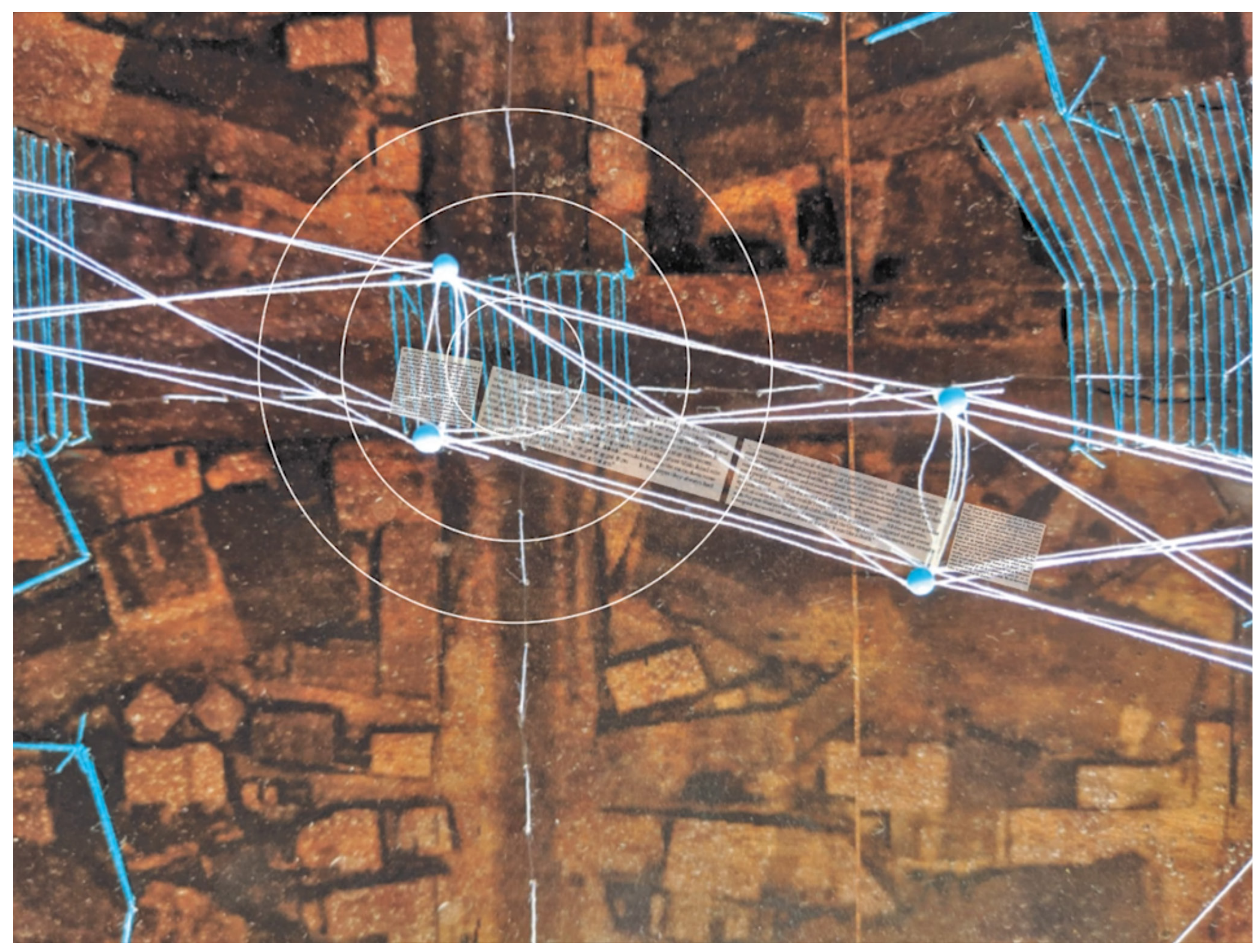

Fig. 38 Video Still, the train moves across the urban environment affecting the spaces below. Please watch: 


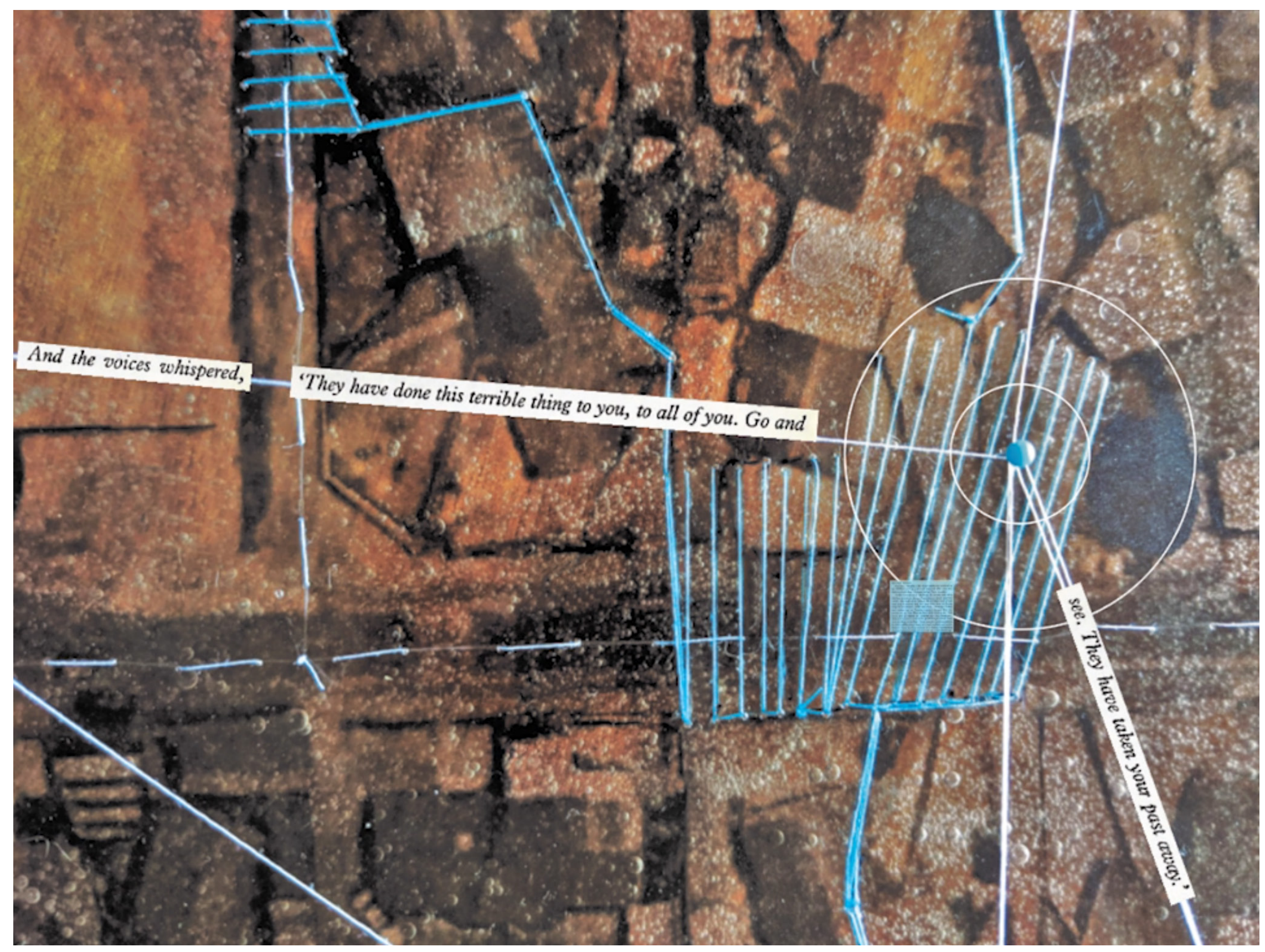

Fig. 39 Video Still, threads pass through acupuncture points, digitally transferring messages through the landscape. 


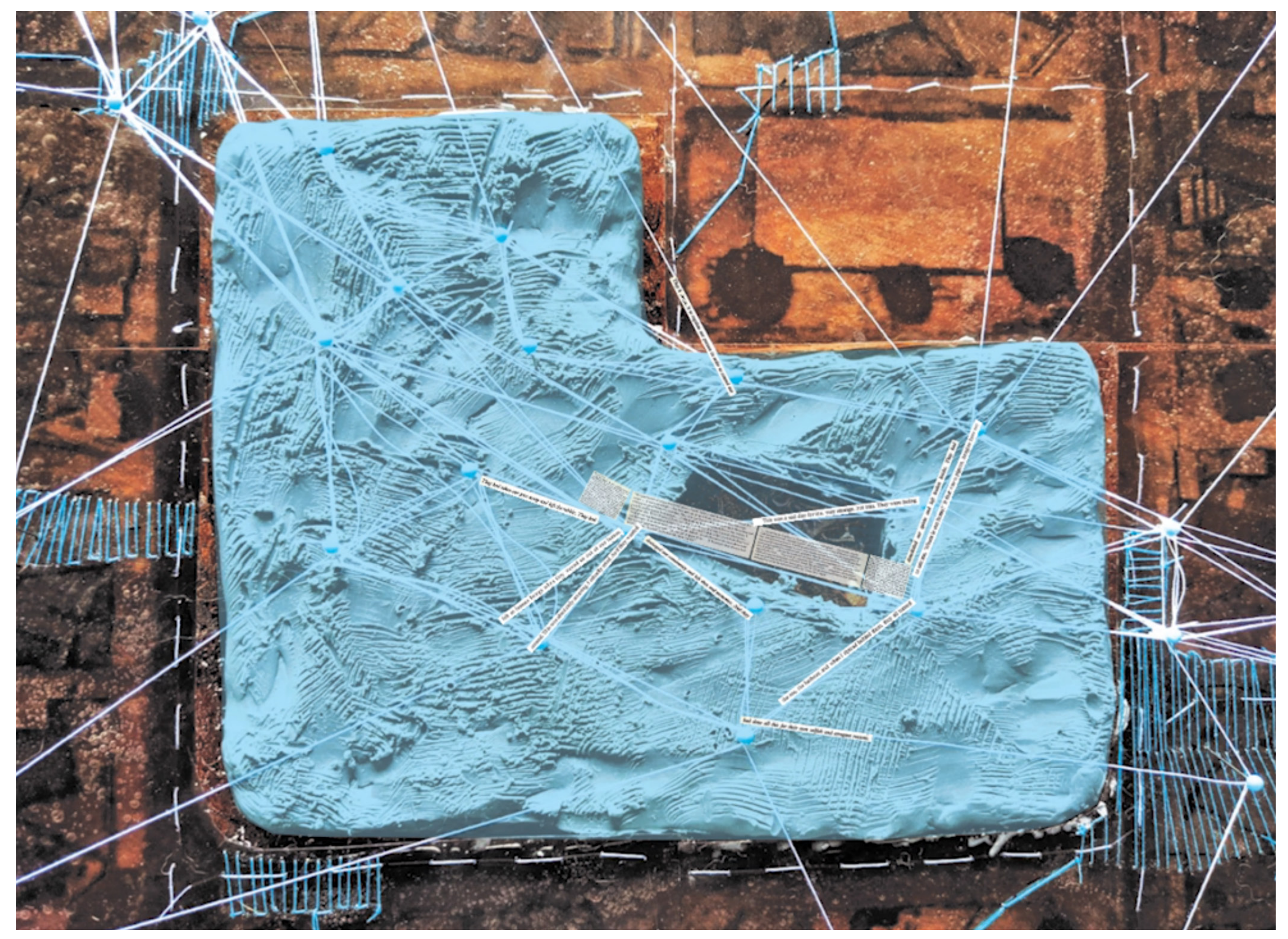

Fig. 40 Video Still, the train arrives at the train station, bringing data to upload to the fabric. 


\author{
Location Fires ${ }^{1}$ \\ Beneath my eyelids \\ the landscape is neavy \\ the people are buried in ground- \\ clinging shapes of houses \\ From Langa to Nyanga ${ }^{2}$ \\ the fires are hidden \\ the landscape is flattened \\ frightened and silenced \\ Where are the fires \\ for me to believe in \\ where are the tongues of flame \\ to lick and conquer the dark \\ In answer the black body \\ of the sky rears up \\ loud with roaring \\ voices of the stars \\ The stars tonight \\ are blue backyard fires \\ studding the black \\ location of the sky ${ }^{3}$
}

\title{
-Jennifer Davids
}

Fig. 41 Jennifer Davids, 'Location Fires' in Chapman, Michael and Dangor, Achmate (eds) (1982) Voices from Within: Black Poetry from South Africa, Johannesburg: Ad. Donker, 97. 


\section{Restoring Voice}

To restore the agency of voice, this project reimagines the train station as a central community catalyst for the creation and production of knowledge, history, tradition, culture and possible future narratives. The reimagining of the train station begins with the production of a tapestry that floats above the station platform. This tapestry is generated by the voices of the people, visually represented through individual threads. These threads feed in the air from both the giant needles on the train line and in the landscape towards the stations, continuously generating the fabric. The way in which the tapestry is created speaks to the agency of voice as data is created and collected from individual experiences of the residents to activate the threads and produce the visual nature of the tapestry. The tapestry itself is composed of loosely layered threads which are made up of text and images. At times the fabric densifies, while at other times it remains sparse. This variation in the fabric creates opportunity for sunlight to cast through, creating shadows of the text, images and threads on the train, platforms and surrounding landscape. In this sense, the shadows symbolically imprint themselves on the existing urban conditions, creating a new layer of meaning and understanding of space within the township. Each individual who participates is represented, and their combined threads form a tapestry which is visible in the landscape as a marker of community identity. Through the creation of a community generated tapestry, the residents are able to constantly reconstruct the imagination, giving their own interpretation and critique of form, space, land, history and the future.

The framework of the tapestry serves as a catalyst for the creation of spaces within the train station. Instead of serving as a place to simply board and disembark from the train, the station takes on multiple platform levels, providing space for potential educational, cultural and recreational activities. Similarly, the ground around the station is activated with giant needles, which provide an amenity for public green space. The platforms are not 


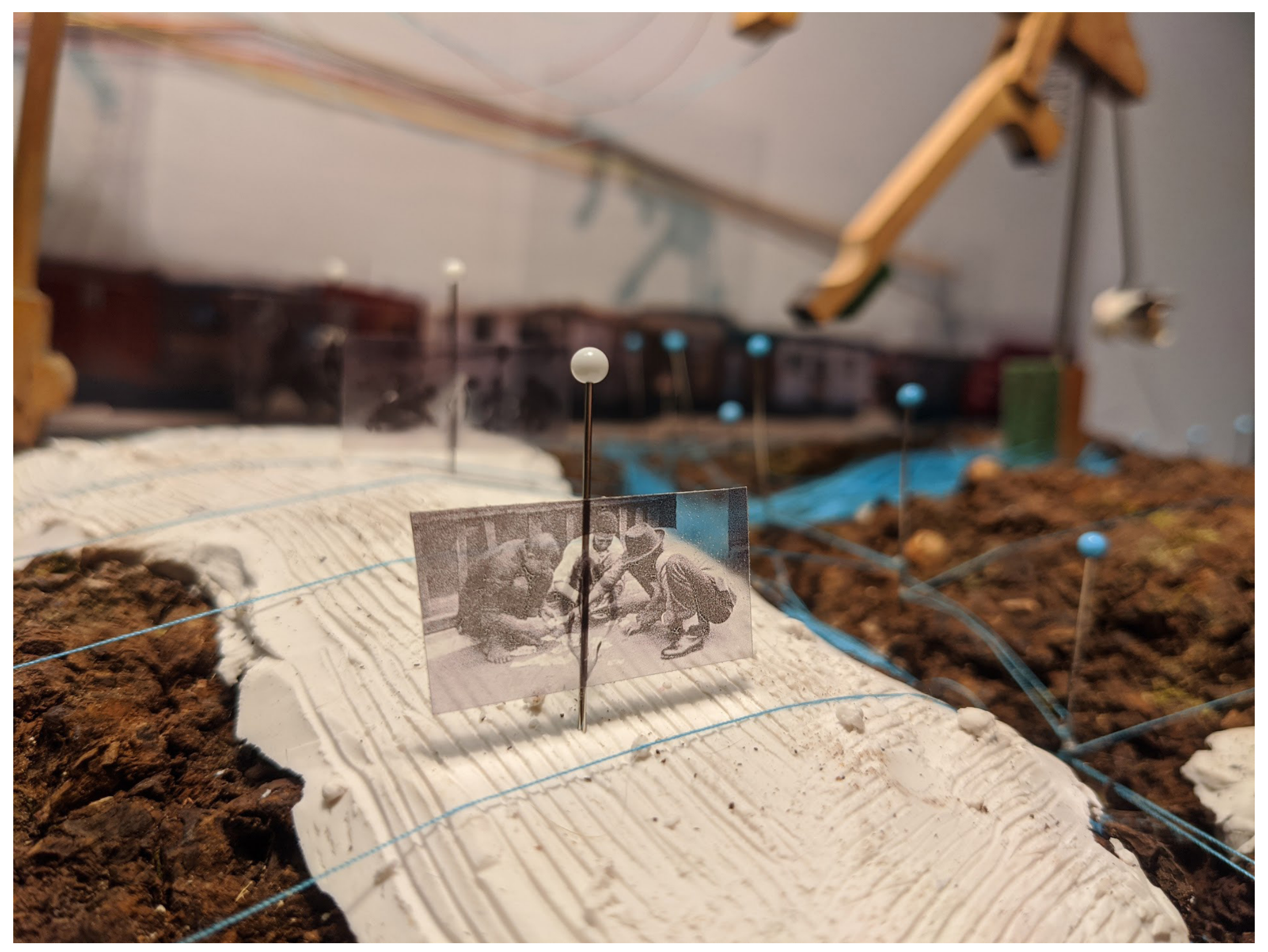

Fig. 42 Past residents of District Six play games in the activated zones of the townships. 


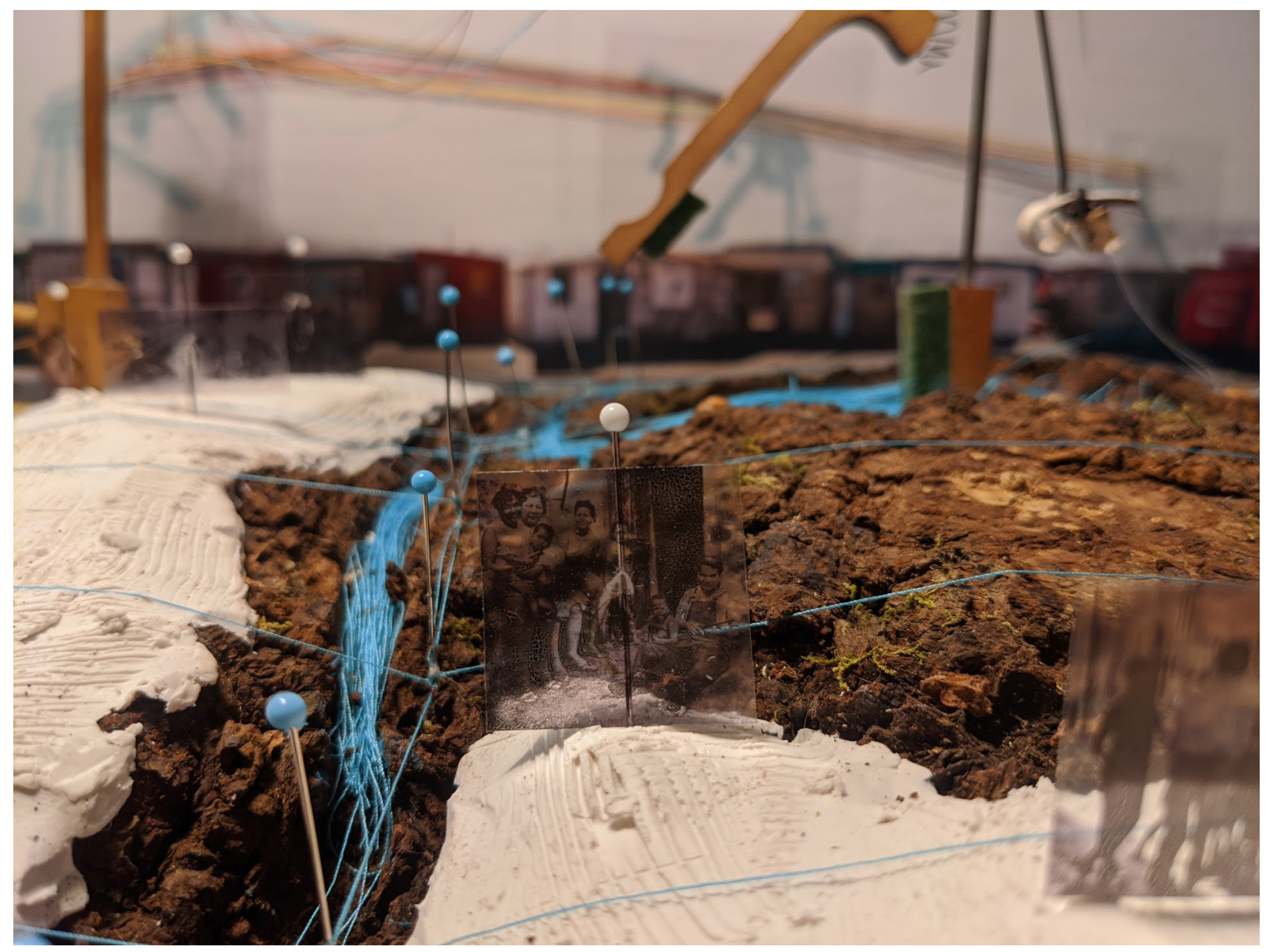

Fig. 43 Physical model depicting the residents in one of the activated sites. 
over-determined spaces and give agency to the residents to adapt, alter and create spaces which suit their needs and desires. In order to give shape to these spaces, the threads from the tapestry touch down to the platforms at various points, helping to define the space use. As the strings intersect, their ephemeral nature brings life to these spaces, creating a play of light and shadows on the surfaces. The residents are able to touch and manipulate the strings, and exist within the space of the tapestry. Within these spaces, residents physically exchange experiences and stories, skills, language, music and engage in sport and recreation. This architectural catalyst serves as a community anchor and hub in which the train station is both physically and socially transformed into a space where the agency of voice is both represented, created and lived.

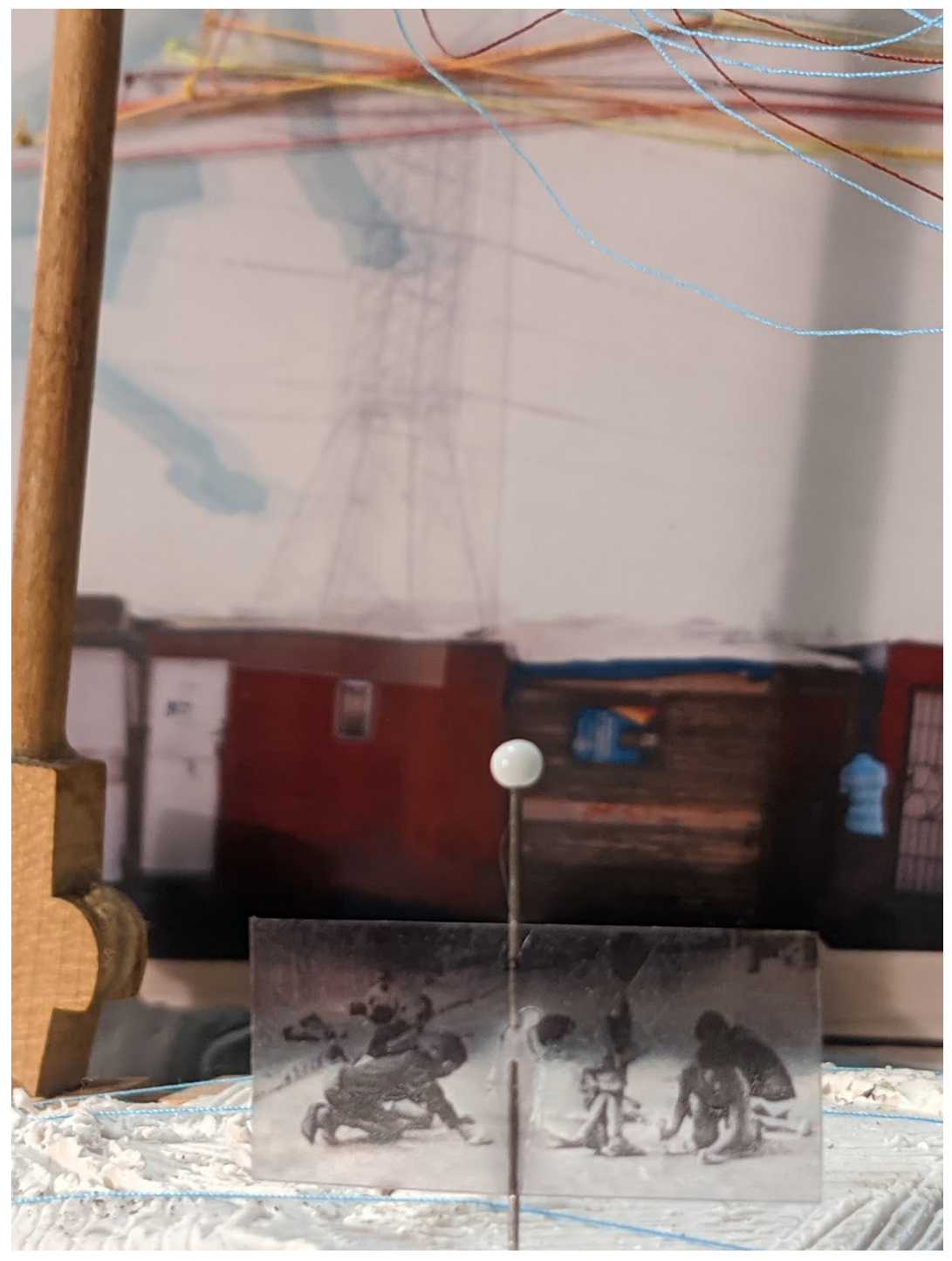

Fig. 44 Children play below the acupuncture needles 


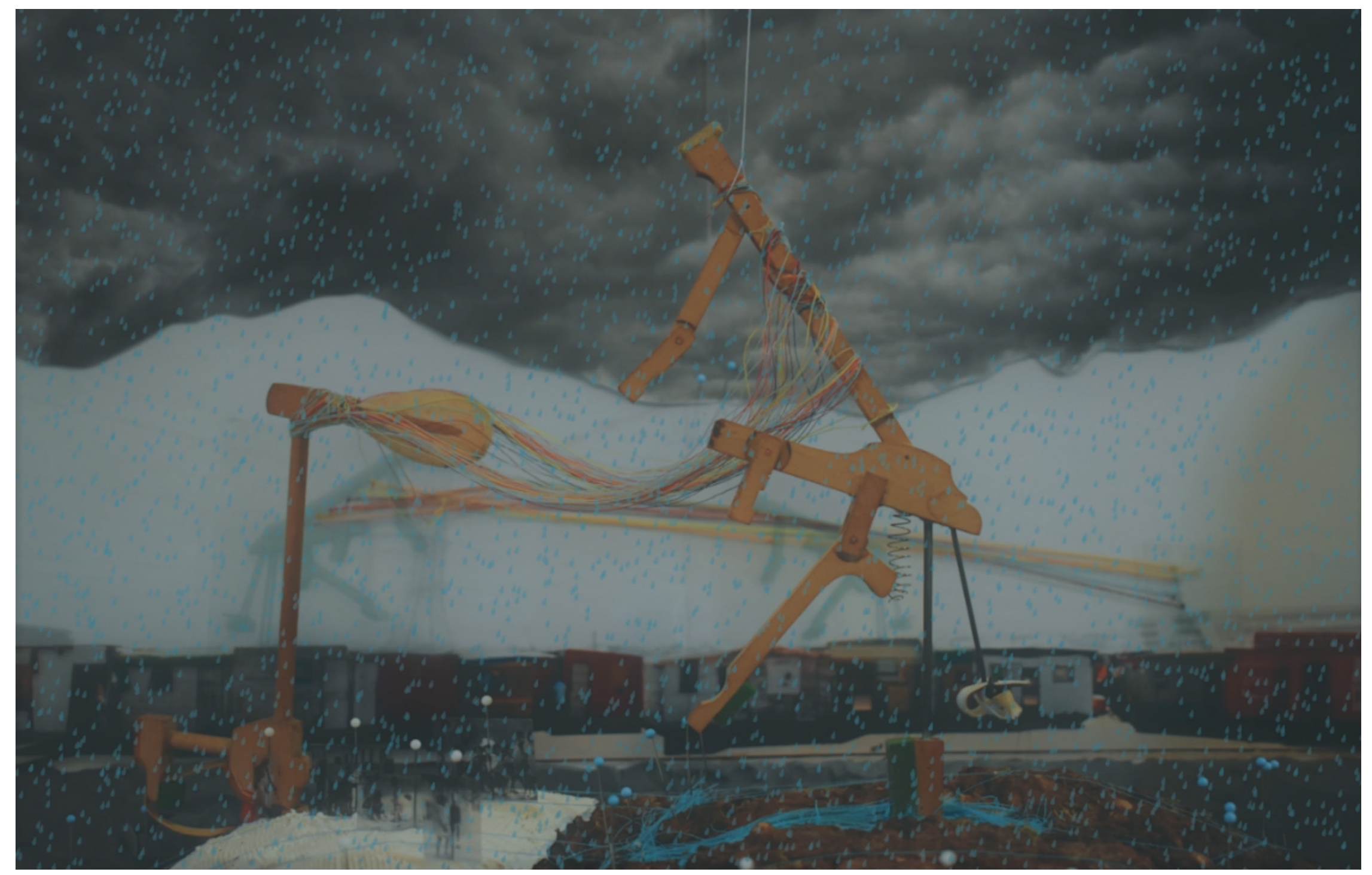

Fig. 45 Video Still, needles collect water for the community on the activated site as it rains. Please watch: https://www.youtube.com/watch?v=0OIXAQfOMrE 


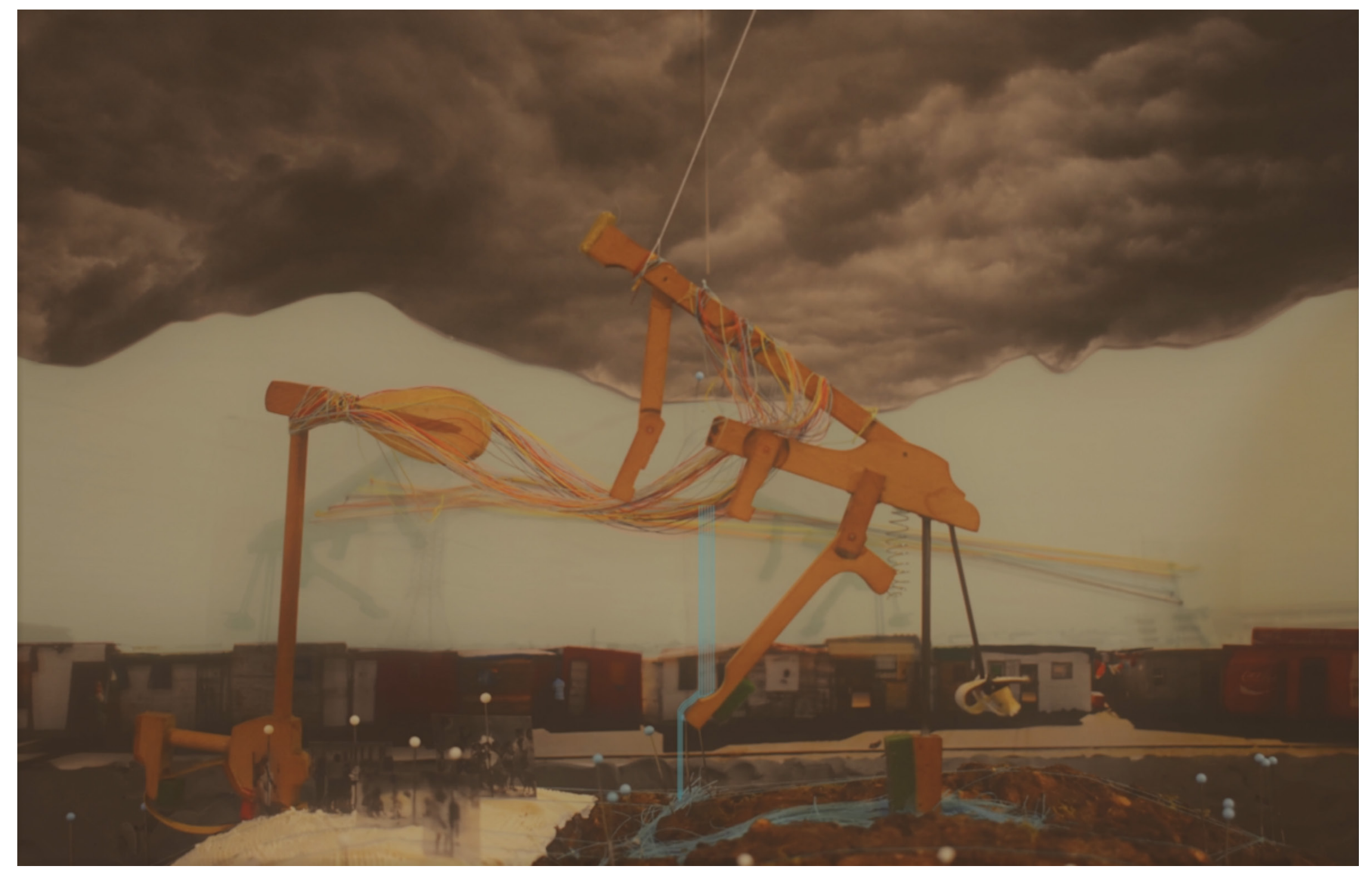

Fig. 46 Water drains from the dense threads into a basin as the needle head moves upwards. 


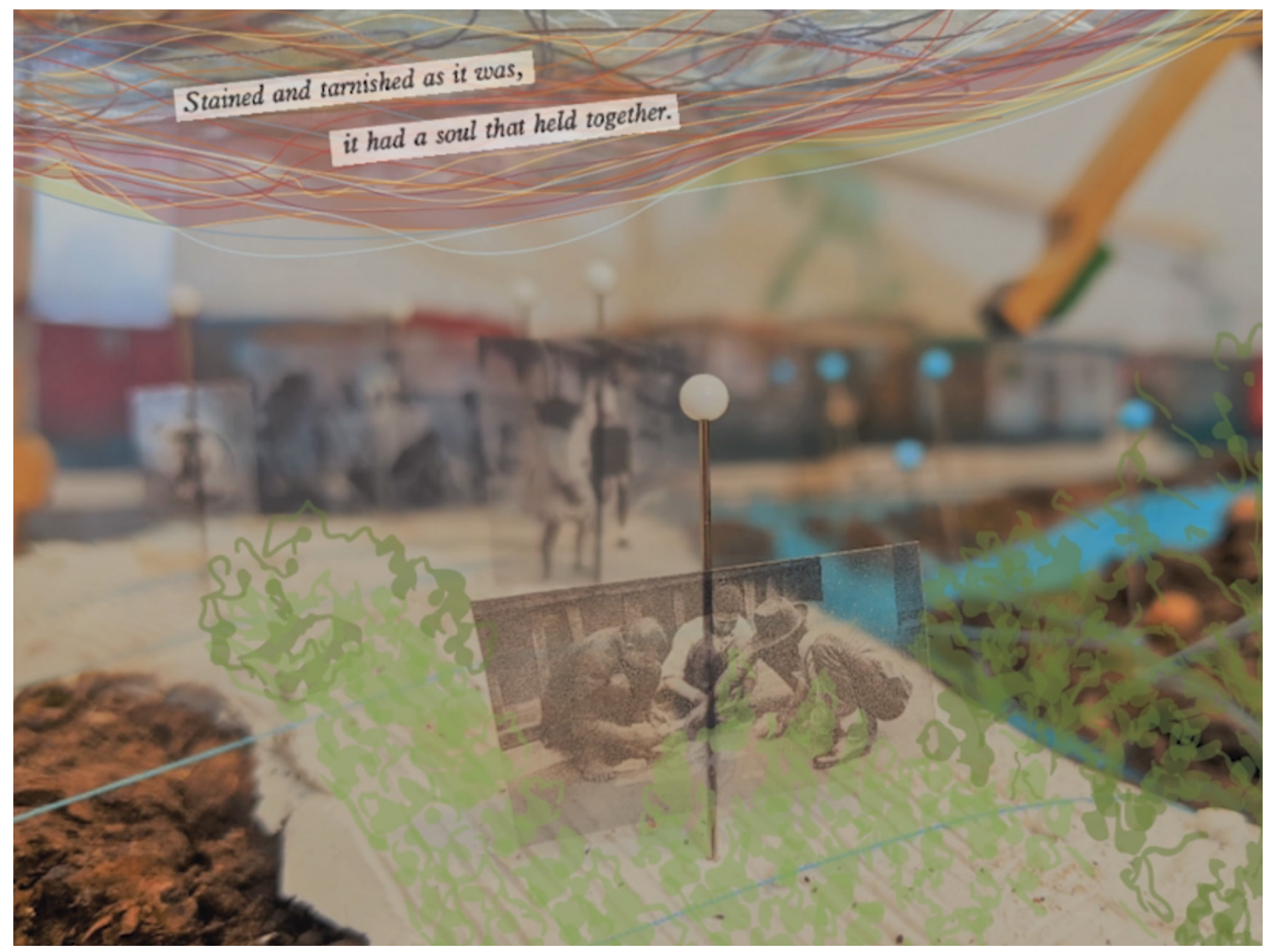

Fig. 47 Growing food under the fabric canopy on one of the activated sites in Langa Township. 


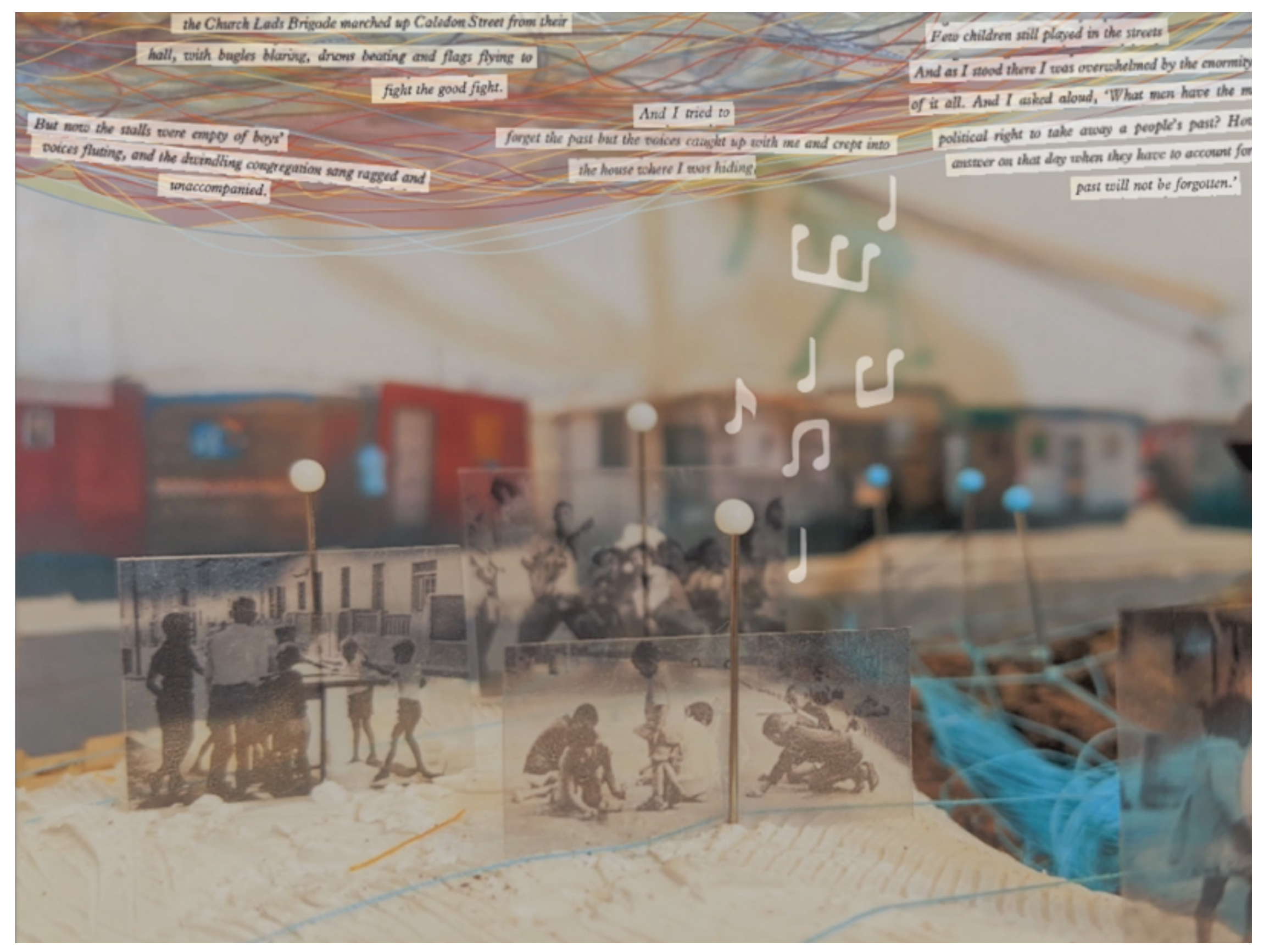

Fig. 48 Residents of Langa Township play games and music on one of the activated sites. 
'They have done this terrible thing to you, to all of you. Go and see. They have taken your past away.'

So I went to see.

\section{-Richard Rive}

Fig. 49 Excerpt from Richard Rive, Buckingham Palace District Six, 1986, 72-80. 


\section{Restoring View}

To restore the agency of view, this project focuses on the reimagination of a train car as a mobile vessel and low rent facility for offices, public services and vendors. Traditionally, the city center has been understood as a place which acts as both a resource center for access to medical, law, monetary and counselling services and as a cultural center with access to the best history, entertainment, art, food and culture. However, the current township condition is one which alienates people from the city center. The proposed train car instead works to challenge perceived notions of the city center, creating an alternative mobile 'center.' The double height of the train car provides space for both public and private uses, creating a condition in which residents do not have to access the 'fixed' city center for these basic goods and services. The act of the decentralization of the city center via the train car works to bring forth and challenge the hierarchies of the existing urban fabric. By contradicting the existing conditions, the train car breaks apart the existing social and physical understandings that some spaces are more important than others.

To give the agency of view back to the residents of the townships, the train car serves as a vessel in which people can actively participate in the creation of the train's culture. While the focus of the train is in restoring the agency to these residents, there is also an important factor in connecting them with people from different parts of the city so that everyone has the opportunity to come together to learn, create and participate in its creation. Acting as a type of public 'street,' the physical form and use of the train becomes an expression of the way of life of the many who use it, instead of a select few. As the residents of the townships and the other members of the city use the train it takes on the cultural complexity of view that was erased from District Six and the townships. In current form, this cultural complexity includes the creation of new types of spaces to house offices, workspaces, recreational activities, a market and seating. Users of the train, through their active participation work to define what the spaces of the train 


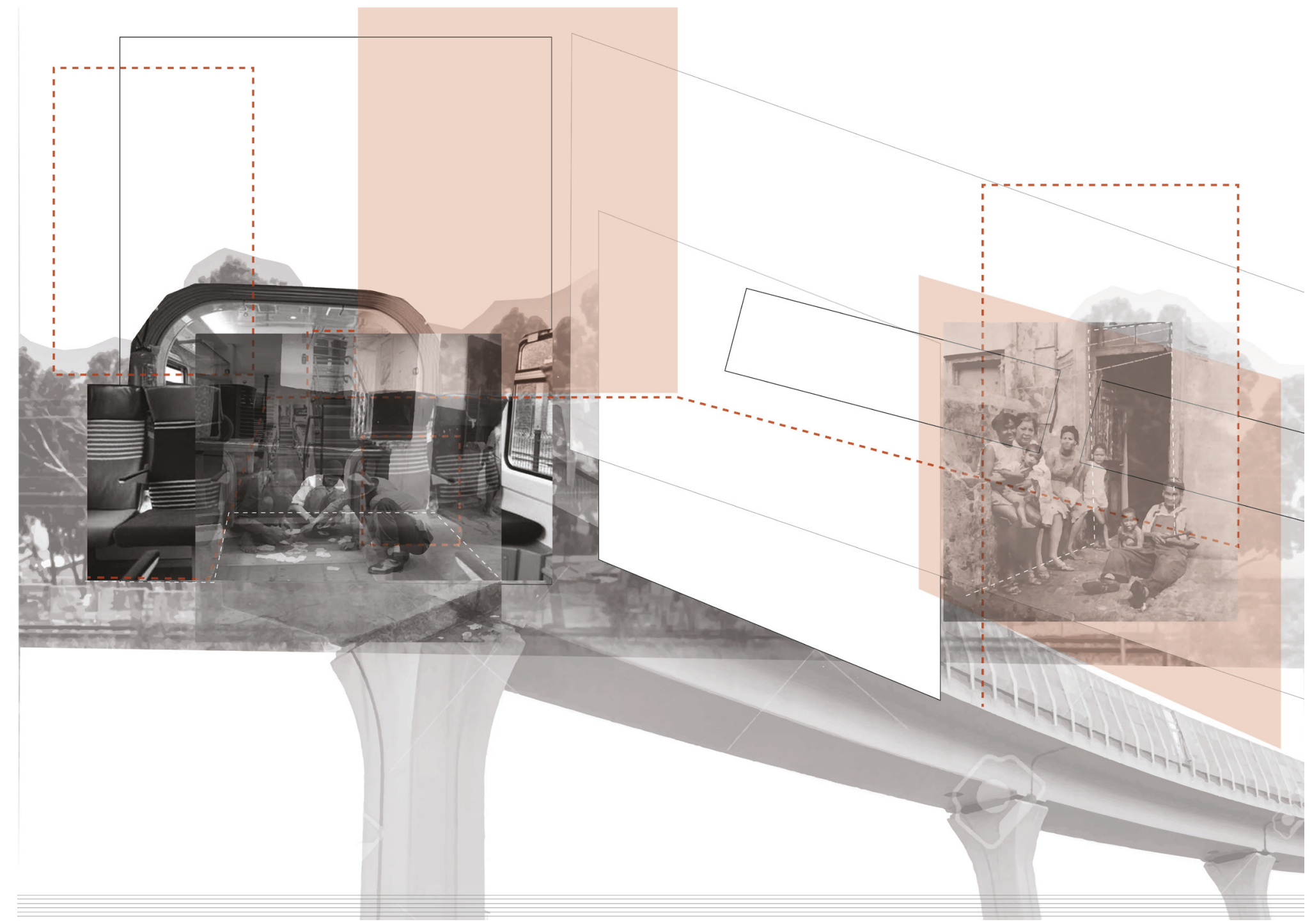

Fig. 50 Conceptual collage for the train. Parts of the train are deconstructed to imagine the possibility of new potential uses. 


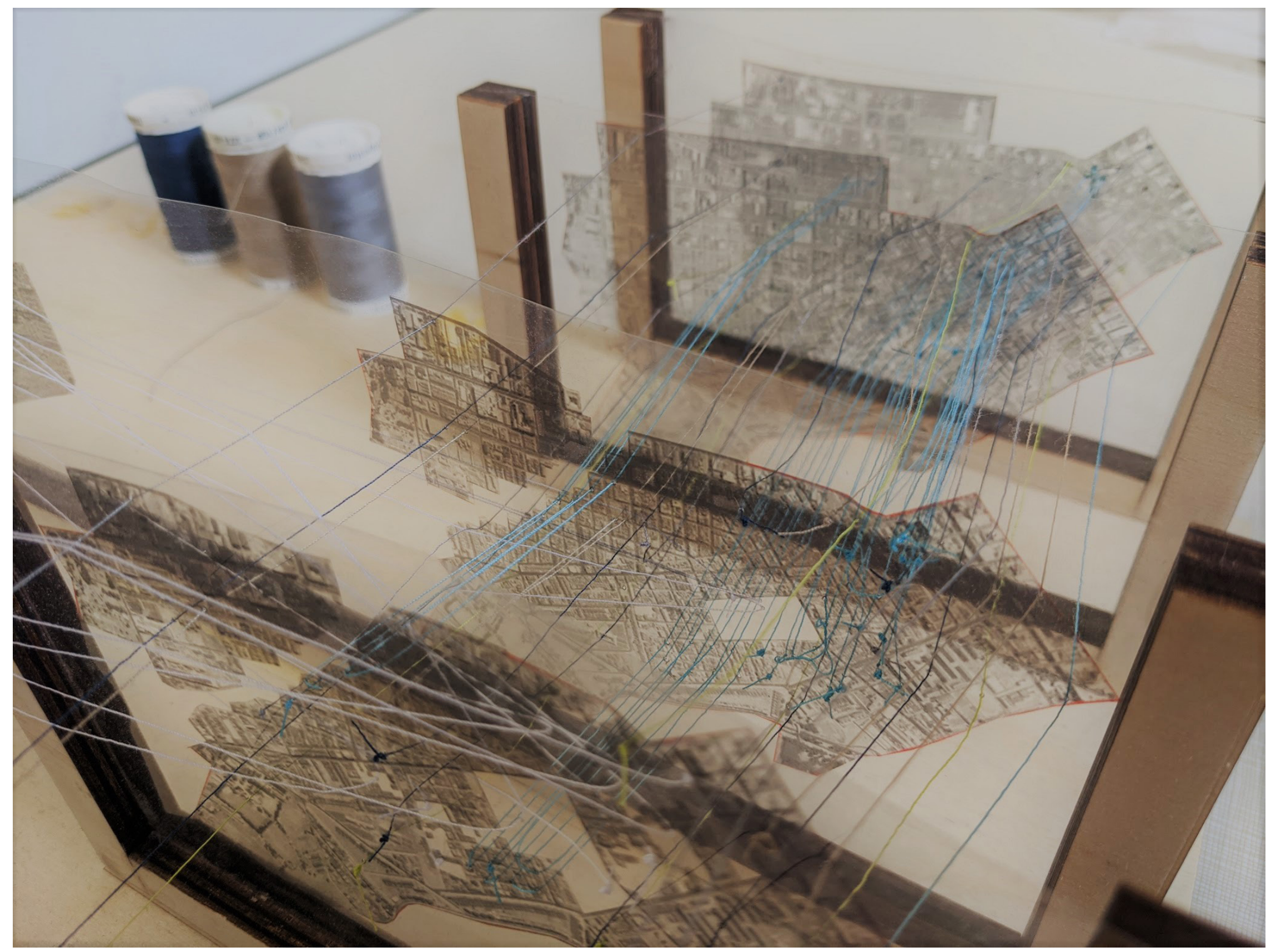

Fig. 51 Early model, strings move through the different time periods of District Six, visualizing what was erased from the site. 
will look like and how they will be used.

The inclusion of public programming on the train also has economic benefits for the residents of the townships. By including rentable space for offices and various services, the rental payments can work to offset ticket prices. In addition, with the constant occupation of people on the train due to the daily use of offices and businesses, general safety will no longer be a concern as citizens will always be present to self-monitor and upkeep the community environment of the train.

Overall, the train car works to restore the agency of view by acting as a catalyst in which residents can create the spaces of meaning that were lost to them. Their way of seeing and understanding impacts the visual environment of the train, but the train also has the capacity to impact their identity, creating a new and more positive expression of self and of home. By creating this new 'view' the residents act to defy the existing conditions of the urban environment that worked to alienate them. Instead, they are able to look both inside the train and outside its windows to a landscape that is a physical reflection and conception of themselves.

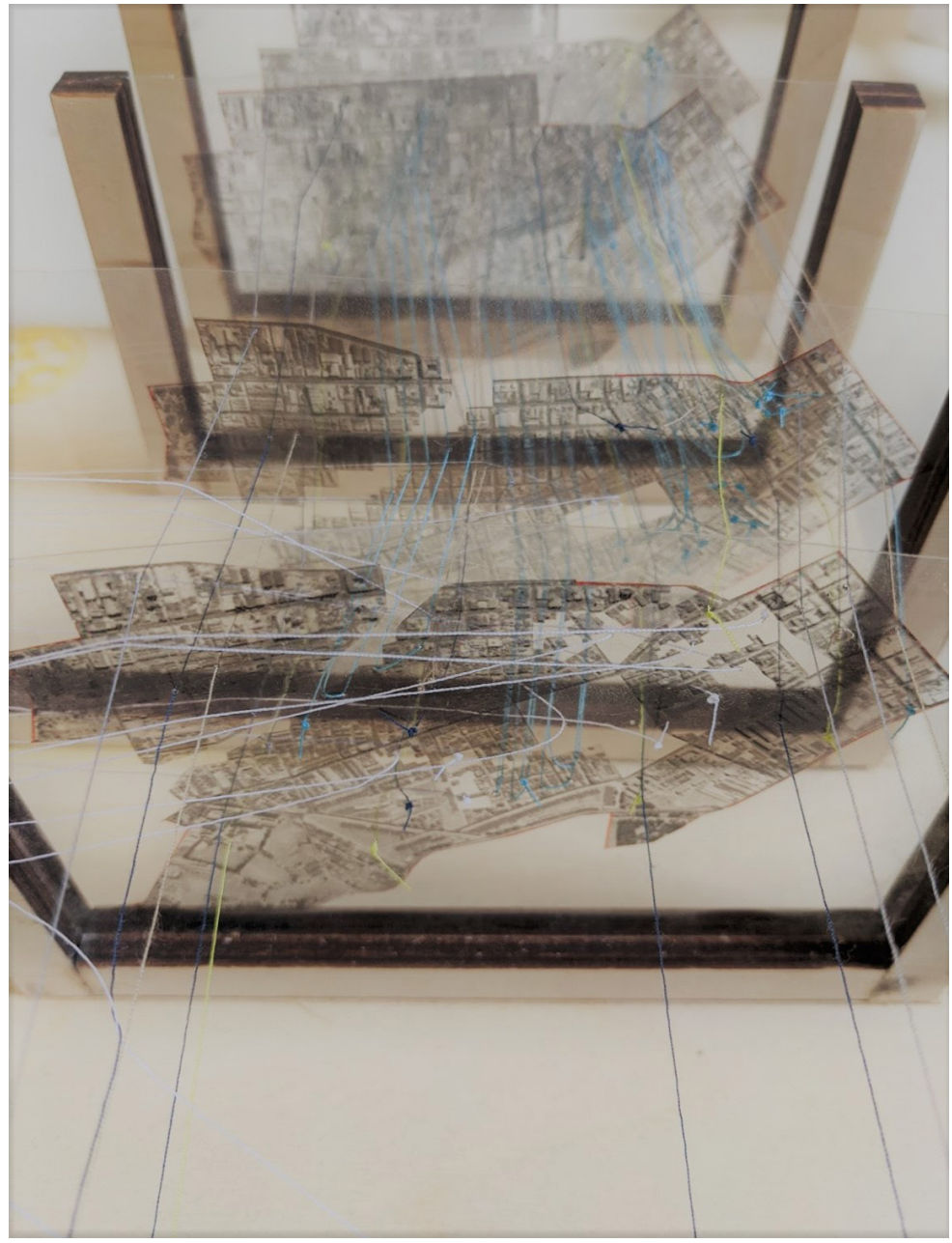

Fig. 52 Over time the site was erased, leaving few remnants of the past urban environment. 


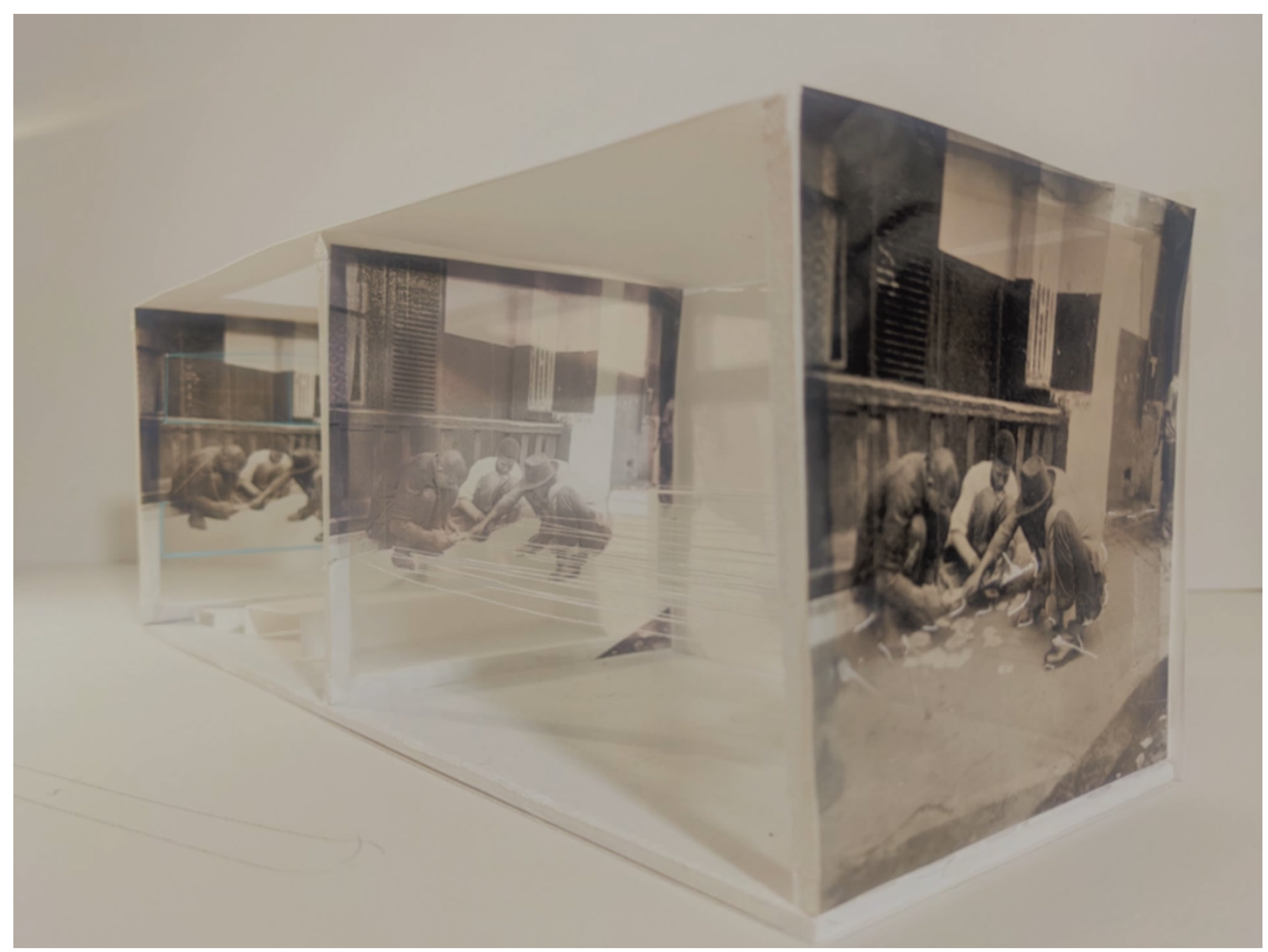

Fig. 53 The train car, conceputally represented through the past, present and imagined future. Please watch https://www.youtube.com/watch?v=7JlRay2Cggs 


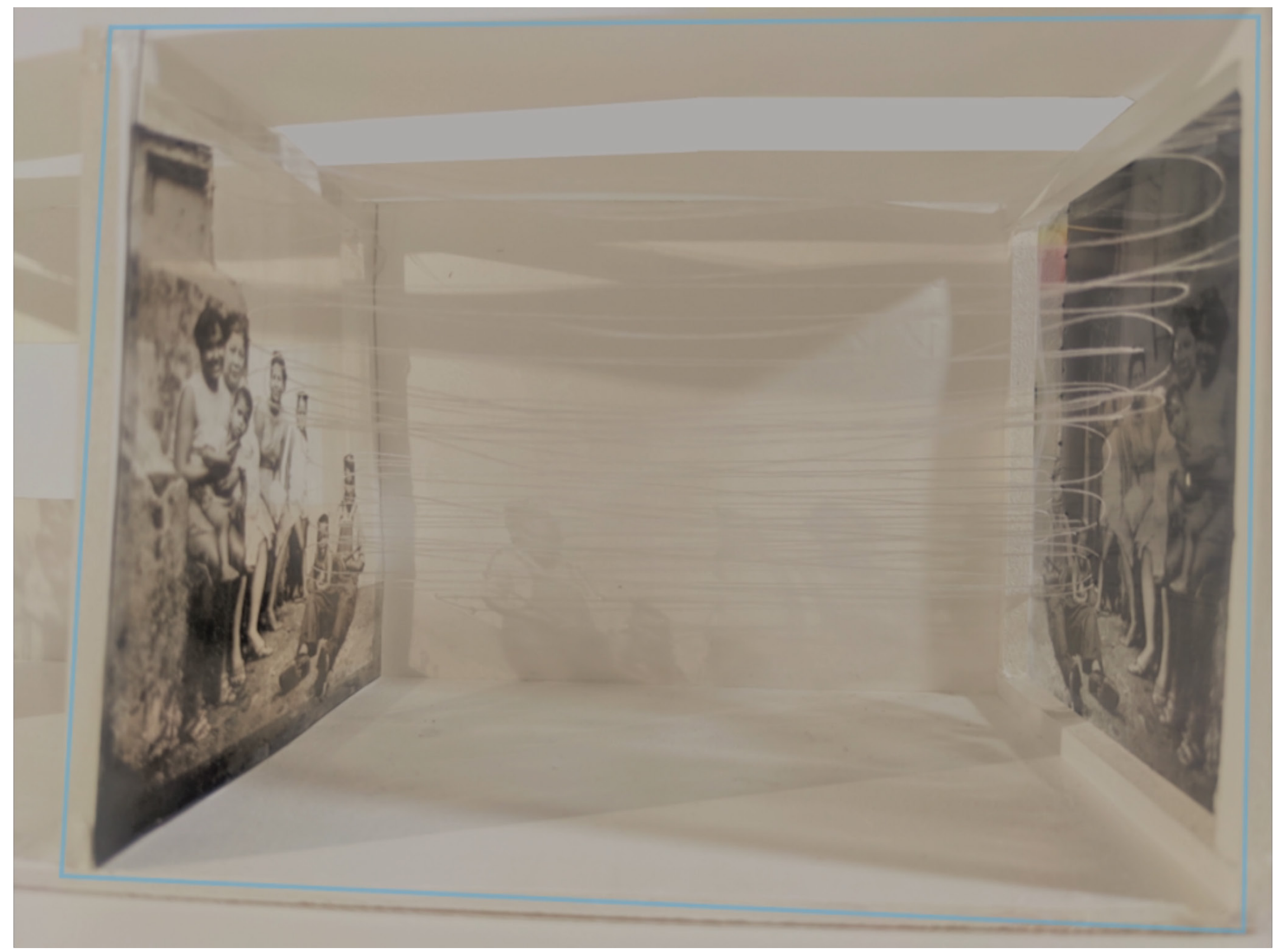




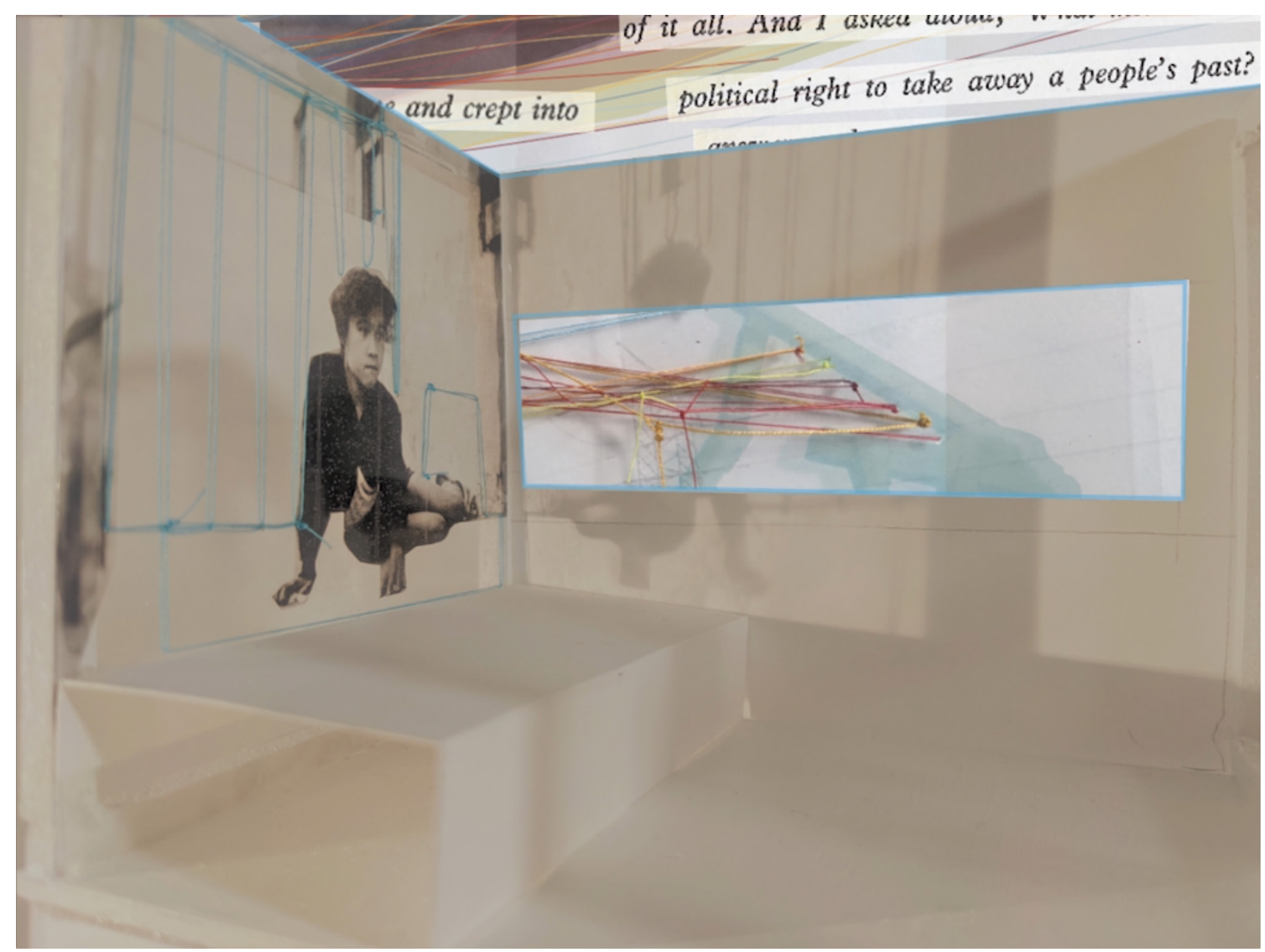




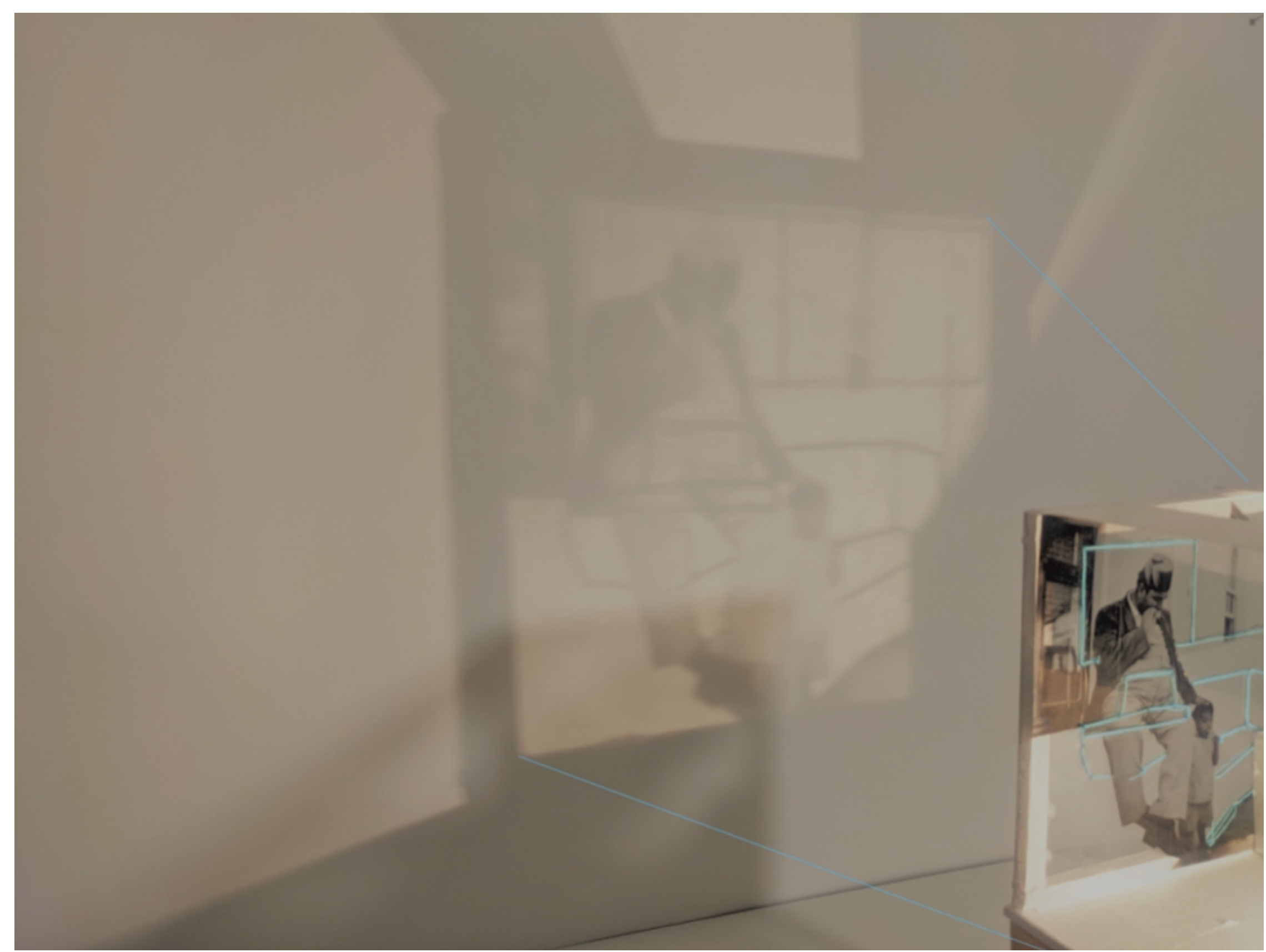


This was a sad day for me, very strange, but true. They were facing the sea, the harbour, and when I tiptoed behind them, they all turned around. This was absolutely amazing. I actually cried. As if they wanted to ask me, 'Where is our home?' If that was a pigeon, imagine how we felt as human beings when they moved us out of our homes. But I always say, we don't even hate them. We forgive them for what they did to us.

\section{-Noor Ibrahim}




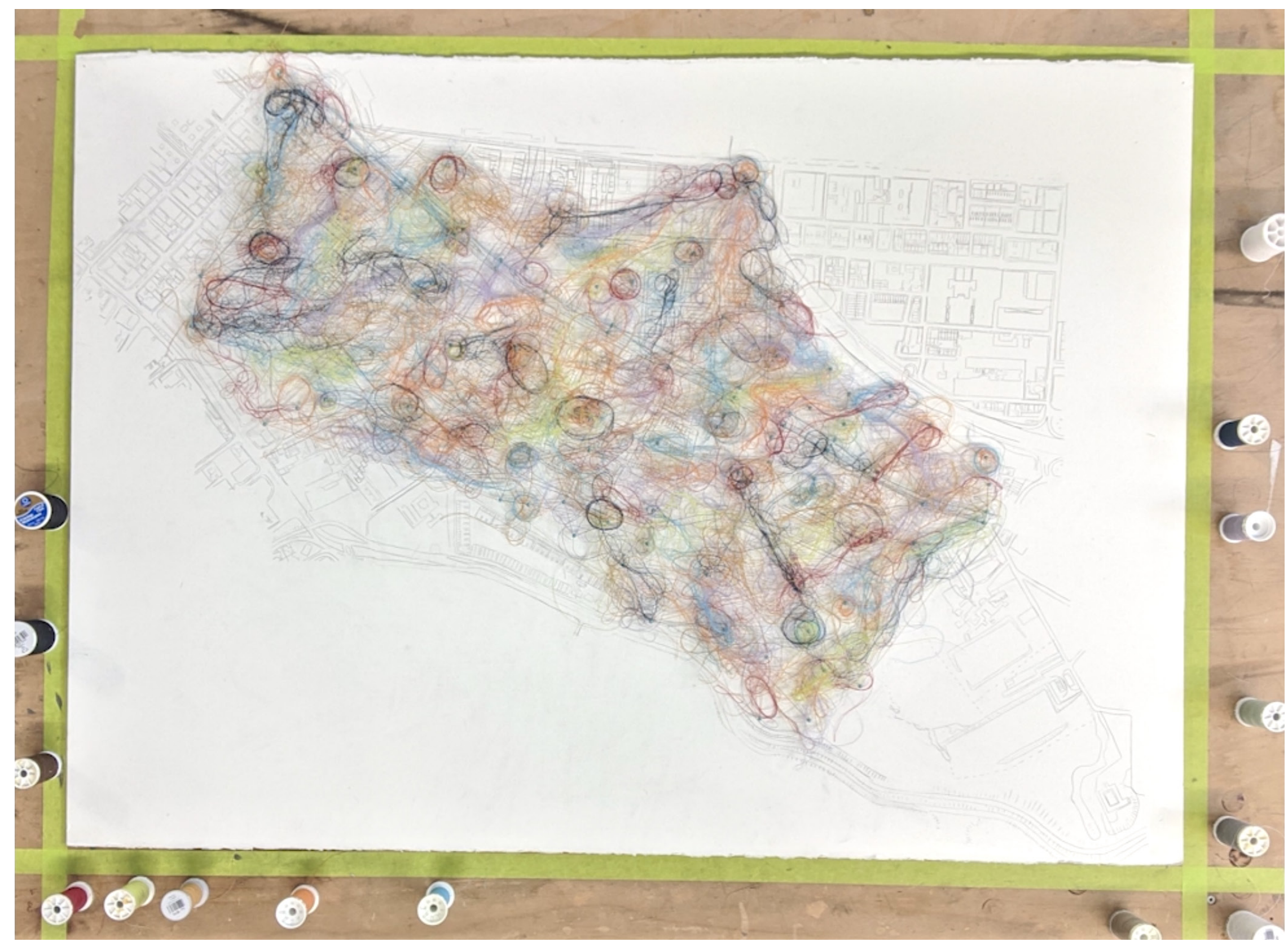

Fig. 58 Video Still, the new fabric over the original site of District Six. 


\section{Agency and the Future of District Six}

At the end of the final chapter in Nic Coetzer's book "Building Apartheid: On Architecture and Order in Imperial Cape Town" he writes, "Perhaps the next time architecture is made to speak it will speak not for the generic but for the particular, not for the a priori but for the unknown, not for something other than itself but simply for itself. For it is when architecture engages in an open-ended dialogue with the particularities of individuals, site, context, form, space, material and light that it pulls people close and also lets them be."106 This statement provides great context for what this project has attempted to encapsulate, as well as what the hope is for the future of District Six. The exploration of agency in this architectural project has been one that has attempted to make an argument for architecture that does not posit 'solutions' with a fixed ideology of understanding and knowing a place and its people. Rather, architecture within the context of agency should speak to the many particularities of individuals and the places they come from. But most importantly, it should work as a catalyst for agency, allowing every individual the opportunity and choice to manipulate, change, determine and contribute to creating the fabric of the urban environment.

The site of District Six has not been an easy place to confront with its multiple layers of understanding and often contradictory viewpoints on what the future of this complex urban environment should be. With the complex political situation and many voices at play, architecture and urban design alone are not capable of providing a solution to the problem. Architecture can however, posit new understandings and provide critical introspection of District Six when thinking about the possibilities for the future.

\section{The New Fabric}

This project imagines a future for District Six in which agency is restored through the visualization of a tapestry that covers the extents of the site. Through 
time the tapestry will grow, with strings constantly being fed from the townships to a final station on the original site. From the station, the threads are fed in the air to needles placed in the landscape on the sites of past residences. Over time the strings collect, become layered and grow, covering the ground of District Six. Between the fabric in the sky and the existing conditions of the ground, strings hang down, touching the landscape. Both the strings and needles work together to create points and paths of activation, creating enlivened spaces with water, greenery, light and people. The fabric stands in the sky, a marker of the people of District Six and their rightful place within the city. Embedded within this fabric is a hope for a future which sees these past residents and their next generation return to the space of District Six; a final act of agency. 


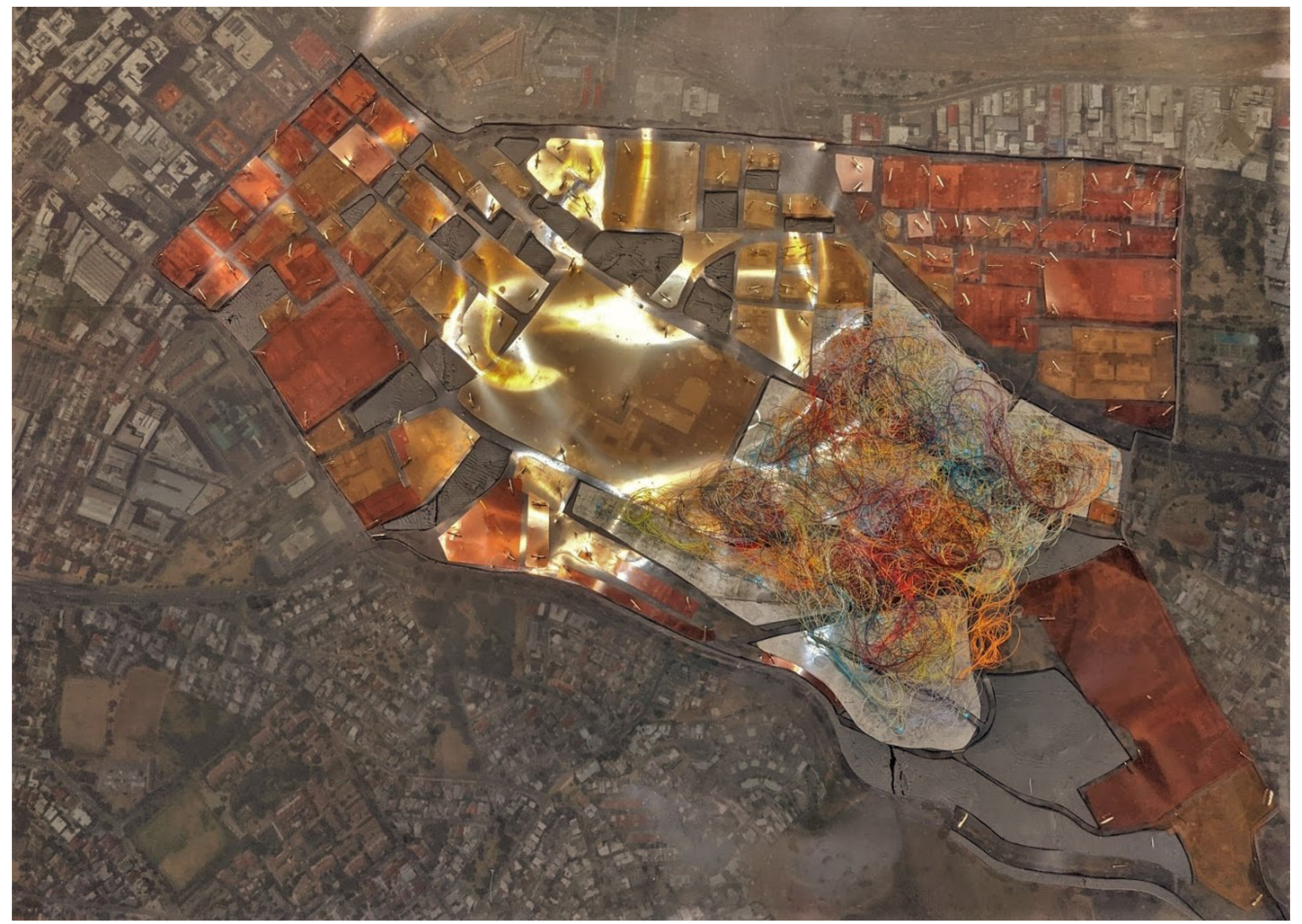

Fig. 59 The clay site model with the new District Six fabric. 


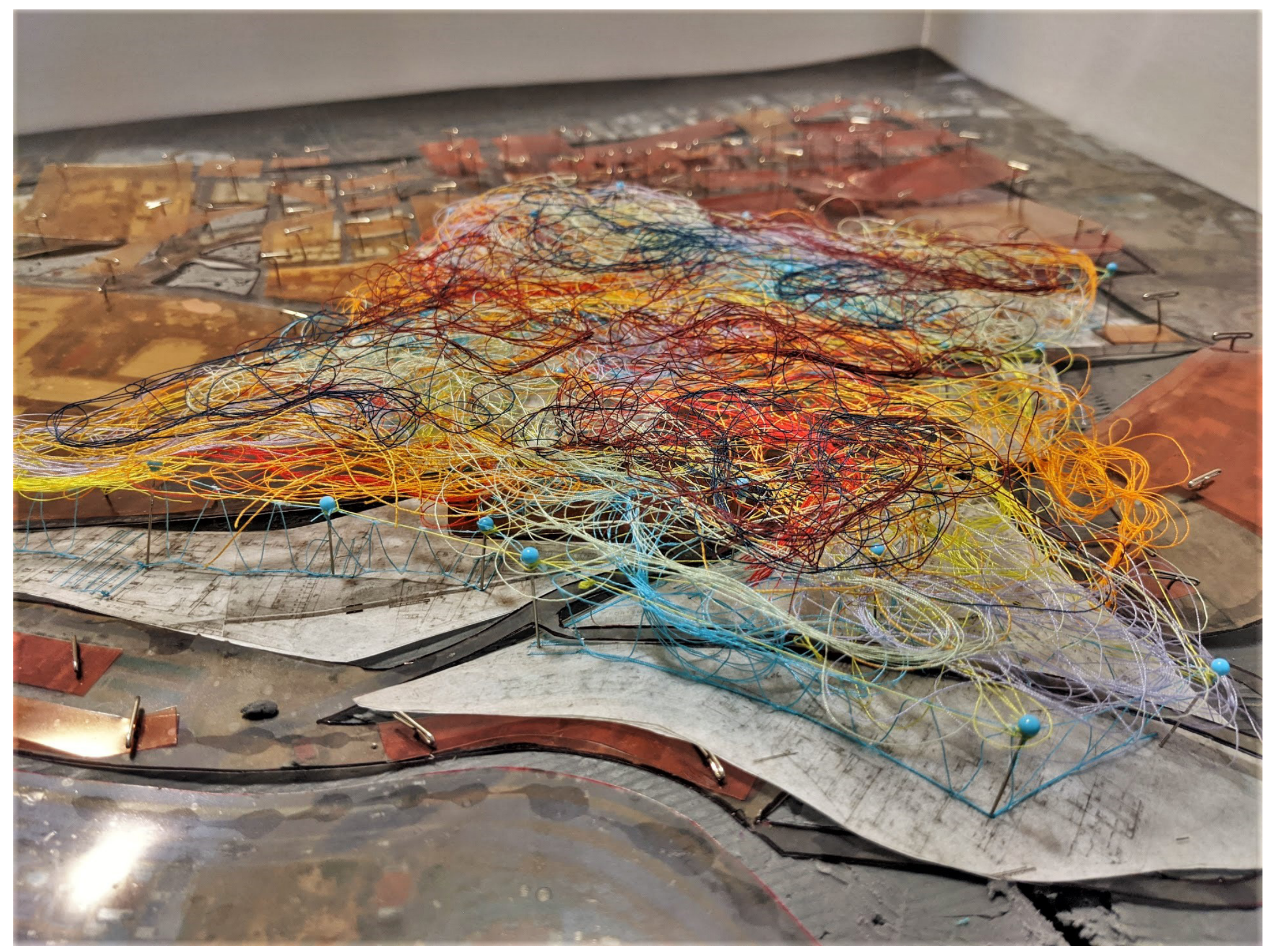

Fig. 60 The new fabric depicts a form which is a representation of the past, present and future. 


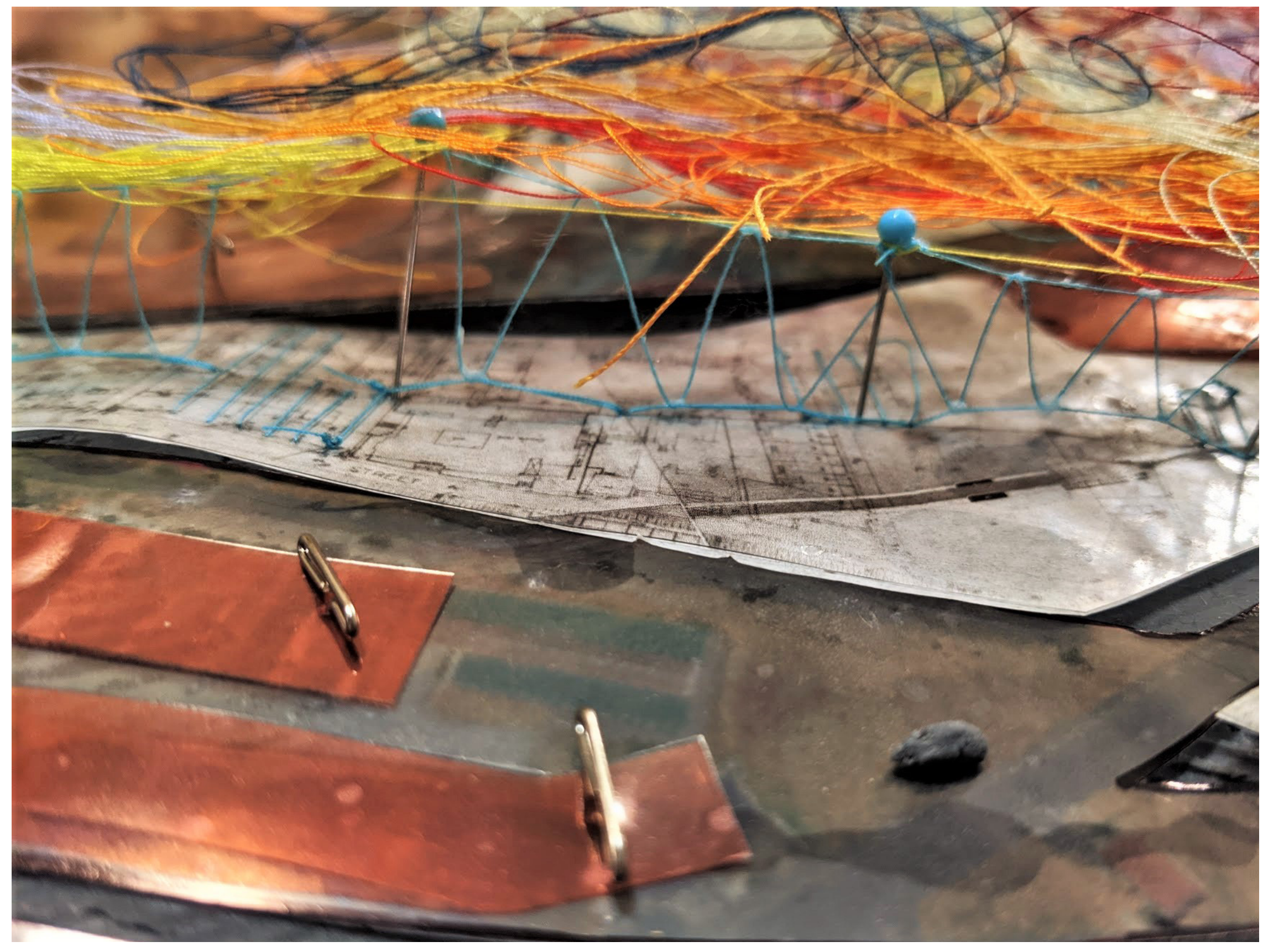

Fig. 61 Threads connect the above and below spaces of the urban fabric. 


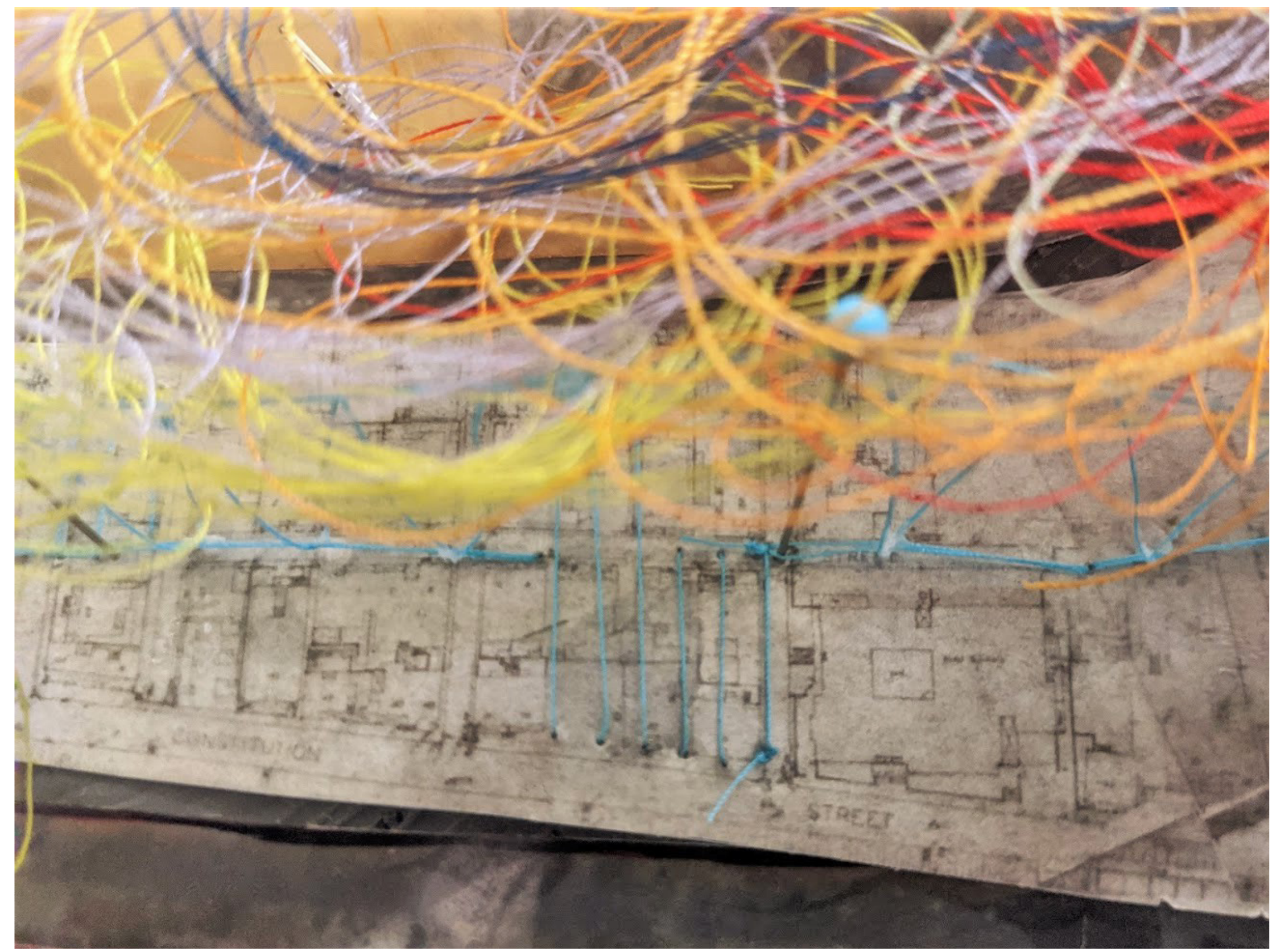

Fig. 62 Activated spaces are a reflection of the old fabric and the new. 


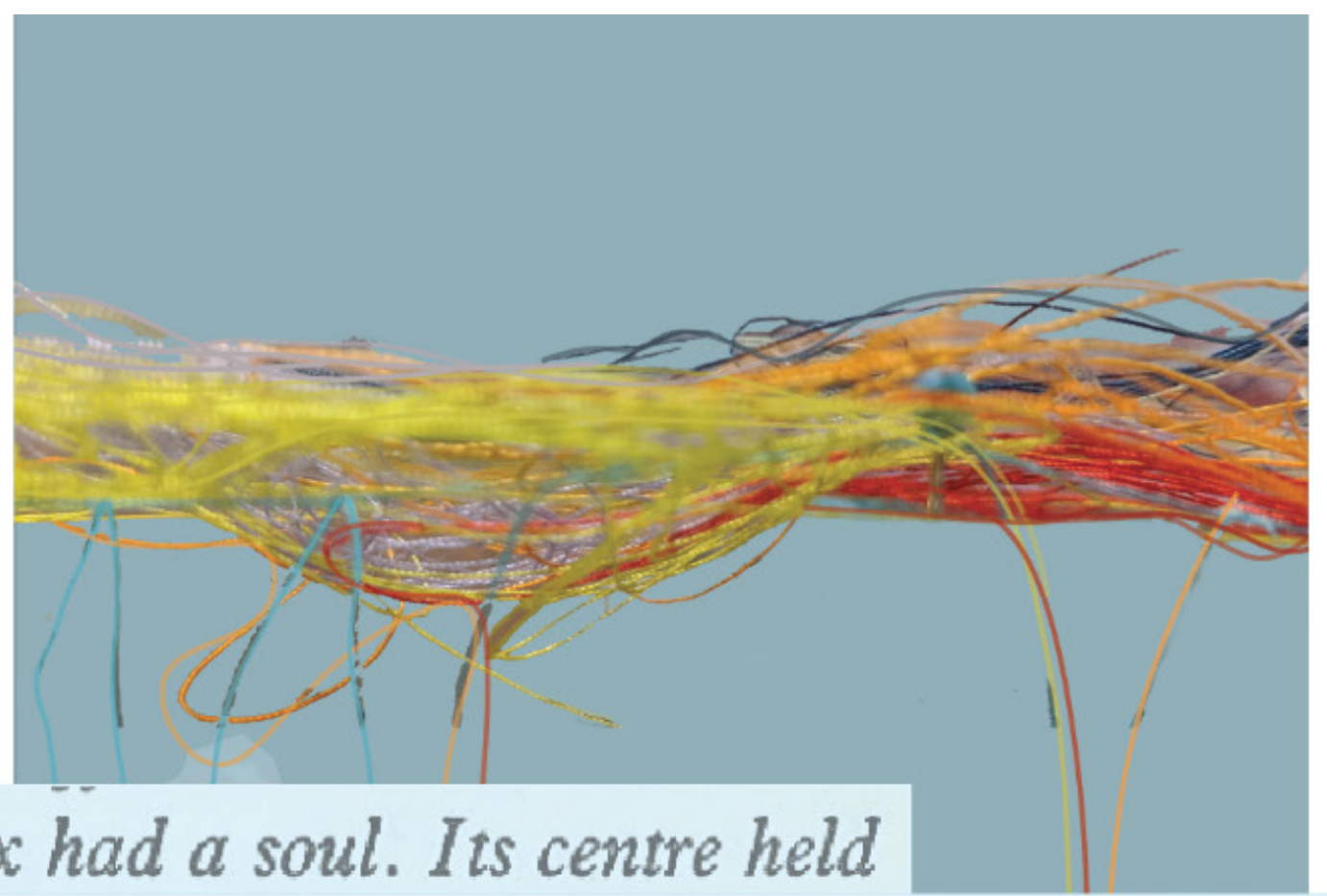

District Six had a soul. Its centre held

together till it was torn apart. Stained and tarnished as it was,

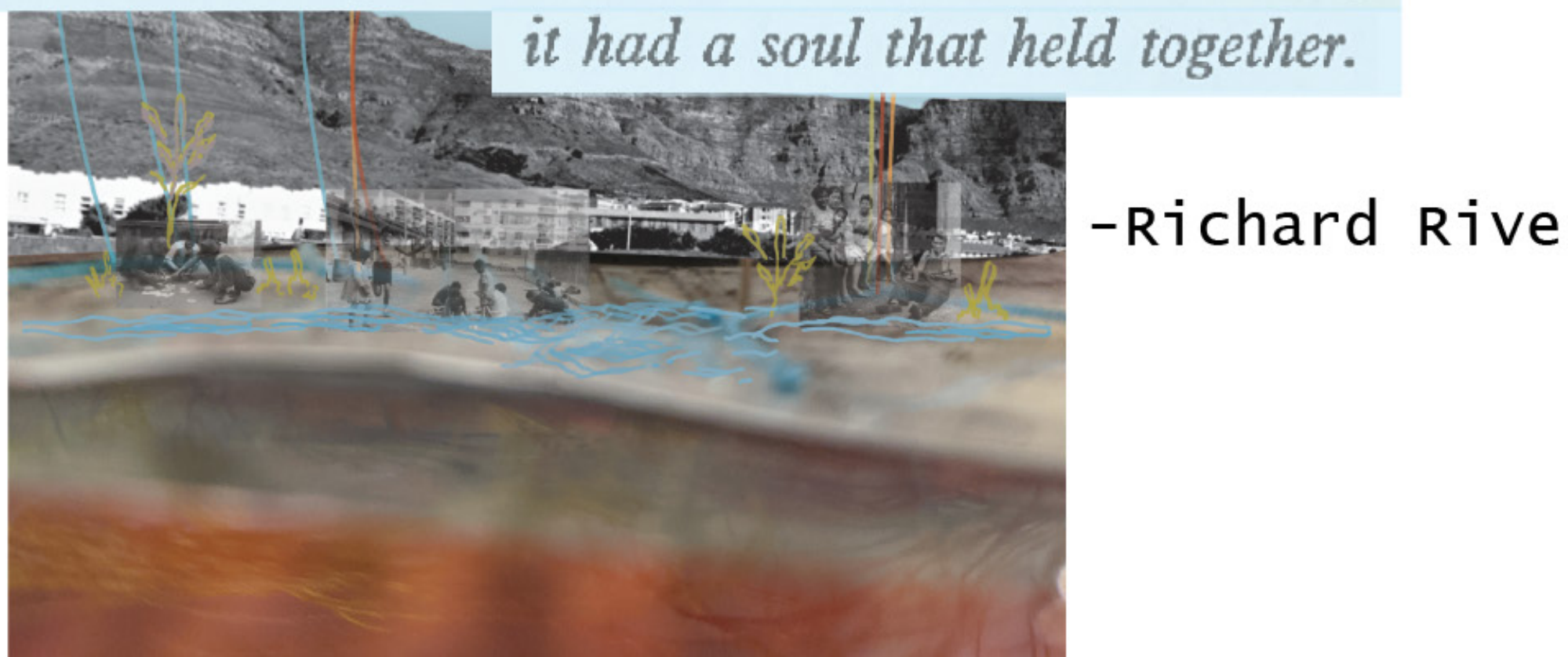


'Taunshp' loaded term, Cake Town most vated ElMcome momalized, Langa Quanter ary for tourists in Avica, go to waternont dated community, scufe space to play, comm for safan (weil develored) peoplet culture thend, moot dweese genetically, tamsnoe meddue of Europen, stabluse communa

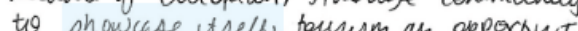

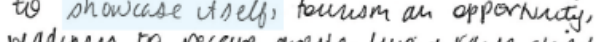
readiness to receure grests, whe + rase cliechen low-self-esteem / worth, can 4 celerate beacknes poo service to trwiships/not hoeduy them accountable, trink,

$56 \cdot 8.000000$ trot

$80-120,000$, densy populated, roadr raie annet expand, motmans jo6s, mary chiedren inet unked to the larger city, 99\% vlack, whete suburb (garler cey movement) idesegned te leep people out pinclands, 17-20,000 pug can oney enter from wity side, other colored communita, pcopcecs middle formed a community, coloreds mexty of Afruans/emopeans, common'(indigenous/ught skensed). Muskins. Rastagarian community, city tryung to rellaw Asticaness, dout Mix, Afluens? cape fars, developmental investment, reeded Cape Fats, devedopmentul in cits, Langa as new aty centre Beleuvil, Cederemont, CBD ( carre)

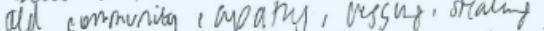
mormalesed, where has tho come from? developinent, cleaver, grearer s dets lort, captured, lavested to do 3 communtres. - racually seperate particupation - rupple who want to remain seperate. LAPP, Lasea Aflucen, Proeards destrict. hew to get 3 communities vs." sidewalks: prodr statuon as unipyine, get kids to imagrie, festivals un stadion, can't ignore e people

Lavla cannot be sles de loaket case. Epportinities

township tounsm do it all here savound food, whe poople can meet want tounsts to come here ficst -ownels people dicuse change - Cape 1own people vito fowinships

207 wormes zoud, put 2od foor - sun Diner, same space orer food conta jos enterpusel entrepeneur work wilpeople who are entrepenewers relognaze themselver, LaPuma knitware

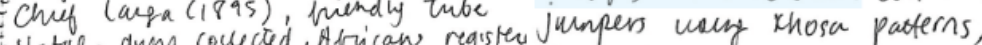

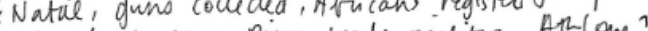
- sewase touatrent blocics station - pre apantherd spacual peanning - desire line, places where people crack vey Vor, wateress cen washer, good cobele, larguase lessons

Fig. 64 Notes taken from a lecture with Tony Elvin while visiting Ikhaya Le Langa in 2019. 


\section{Epilogue: A Personal Story}

In February 2019 I embarked on a 2 month long trip with 10 of my classmates to visit Cape Town, South Africa as part of a directed study abroad. While there, we had the opportunity to visit Langa Township, where we collaborated on a community project with the nonprofit organization Ikhaya le Langa. Within the span of a week we had come up with three proposals for a space on the site which would help facilitate the director Tony Elvin's vision for a community marketplace. To get to know the site and township better, Tony and some of the local boys who worked at Ikhaya le Langa took us on a walking tour of Langa Quarter. Prior to this tour we had already formulated many conceptions of the township just based on our drive from the Cape Town city center suburb of Gardens each day to the township on the outskirts of the city. Sometimes our uber drivers would cancel on us last minute when they realized where they were taking us, and many told us that they would only drive into the township if the drop off point was on the

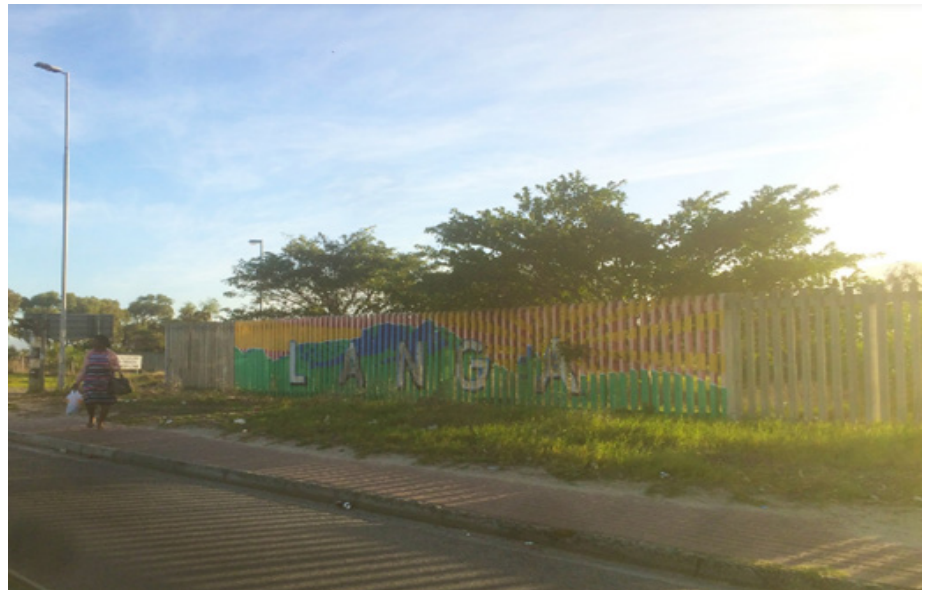

Fig. 65 Langa Township. Photo courtesy of Laurence Massicotte.

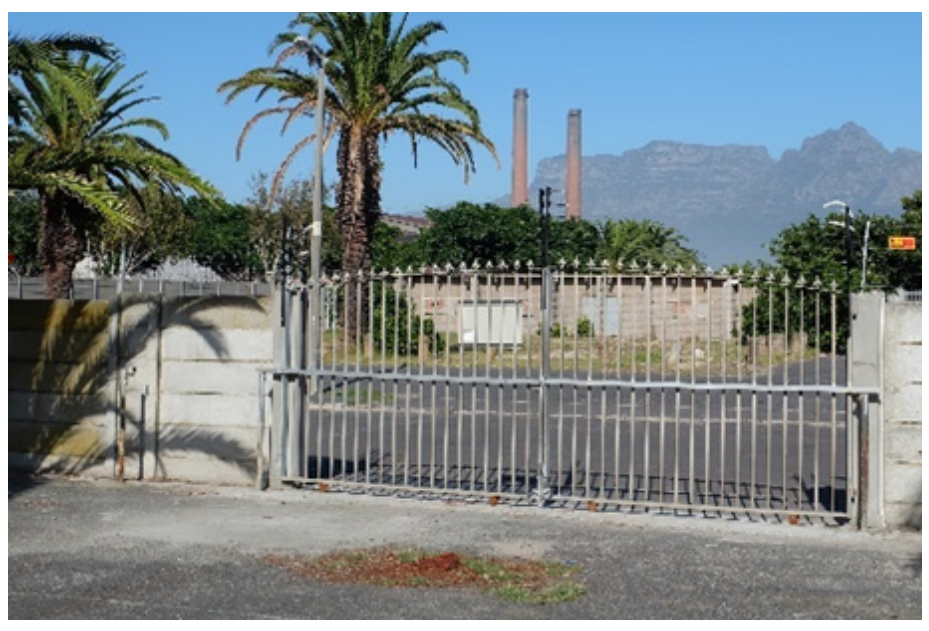

Fig. 66 Langa Township. Photo courtesy of David Woodruff. 
outskirt of the township, so that they could exit the area as quickly as possible. We also found our uber ratings quickly deteriorating as many drivers were not impressed they had to either drop us off or pick us up from that location. Once there, we were warned, "Go inside the gate quickly, I will wait here until you are safe," and "Don't even take your cell phones out of your bags when standing on the street." It seemed that the to be safe in Langa required one to be surrounded by physical barriers and security fencing.

When we finally began our tour and started to make our way further into the township it was not surprising to see the run down homes, informal settlements, litter and garbage strewn about on the roads. Tony pointed out spaces where children played that were fenced and covered in razor wire; it seemed a strange contradiction.

But then came the parts of the tour that did surprise me, and I really had to question my own biases when thinking about what this township was. Even

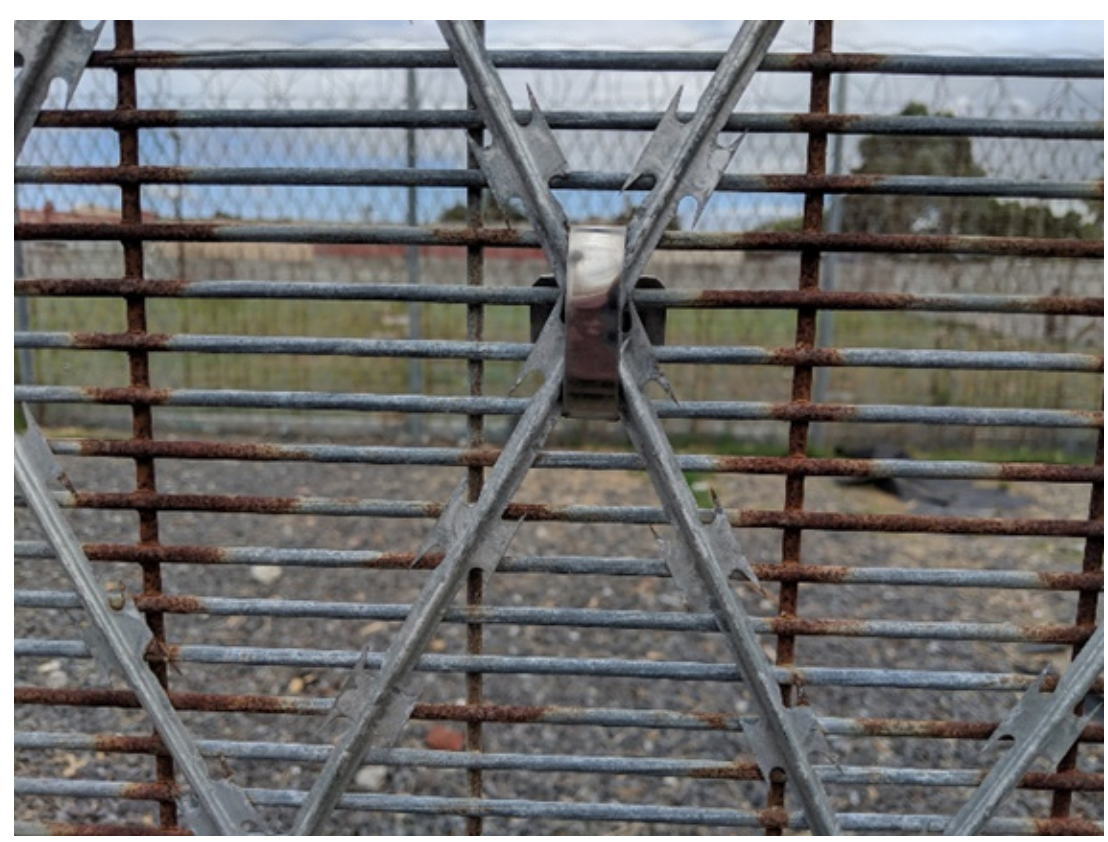

Fig. 67 Razor gate where children play in Langa Township. Personal photo. 
though I was experiencing its physical state and aware of its spoken reputation, there were also small moments of agency that were breaking from the narrative of these histories and stereotypes. There were children using the street as a place to play together, artwork on the walls depicting the beauty of the community and small restaurants and businesses run by families out of their homes.

When we arrived back at Ikhaya le Langa, Tony told us more about the young boys who worked with him on the site. By employing them to help upkeep the building, as well as run some of the businesses on the site, Tony felt as if it helped to instill in them a sense of pride in themselves and their community. He explained that people in the townships more often than not grow up having low self-worth based on the prevailing belief of the township as a derelict part of the larger city.

Hearing this story and taking the tour that day, I began to think more about the potential of architecture and its ability to provide space that facilitates agency.

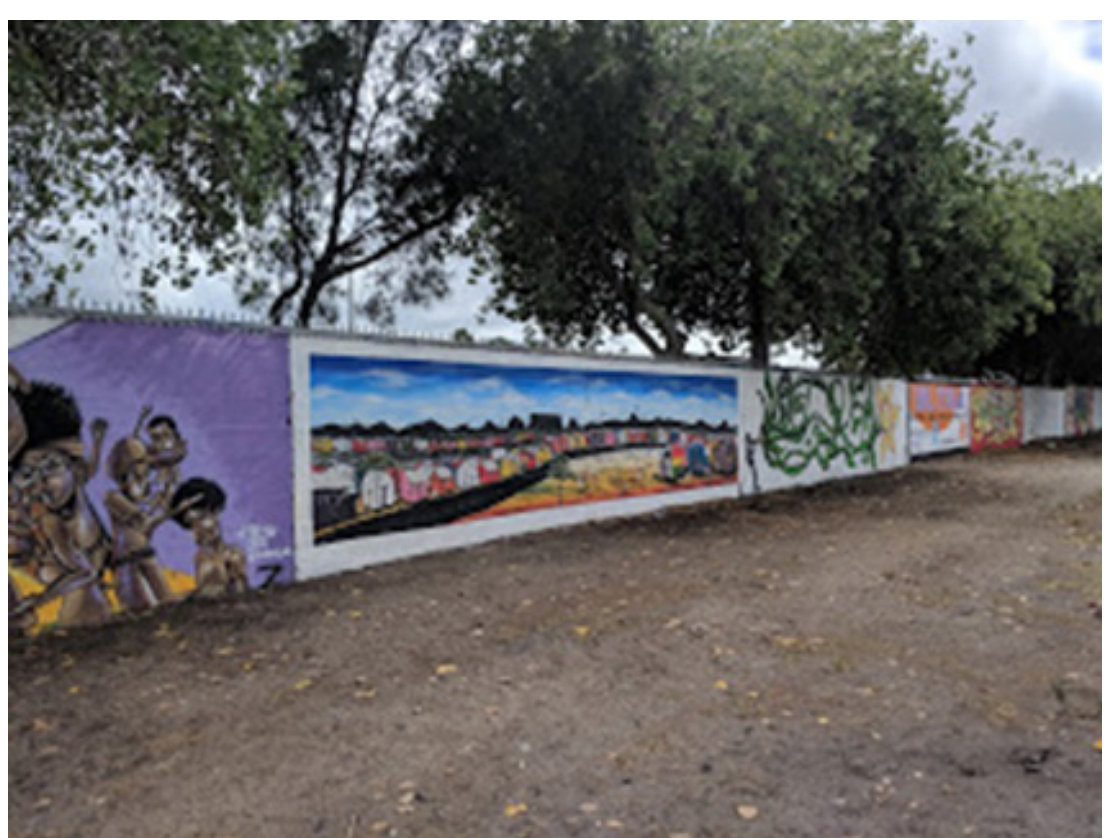

Fig. 68 Community art in Langa Township. Personal photo. 
Agency does not always entail the action of some grand, heroic deed, but rather is often composed of small actions, which over time have far reaching affects for people and communities. Langa and many other townships experience immense hardship in terms of access to economic opportunity, infrastructure and other basic services which have left people and their communities in a continuous cycle of poverty and have contributed to their negative portrayal.

For the project we constructed during our studies, and for this current theoretical proposal for District Six, it seems to me highly significant to understand the potential of architecture to act as a symbol of worth and pride in a community and as a tool to give people the agency to pursue economic opportunity, a better standard of living and the ability to decide how they

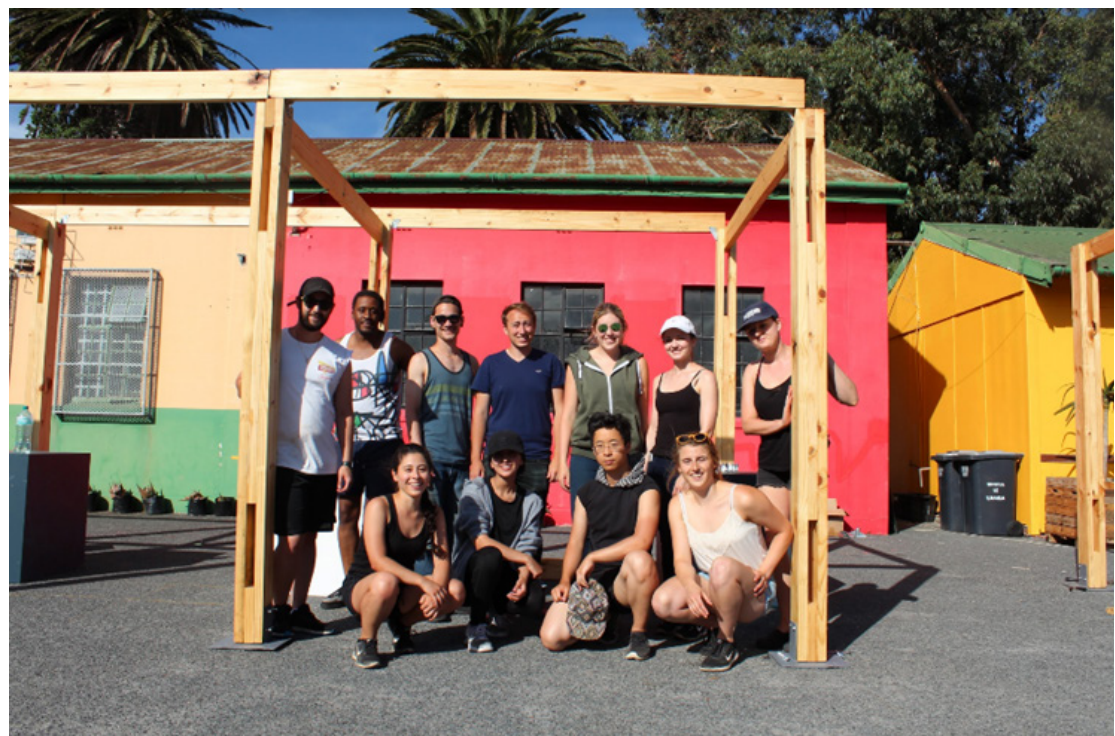

Fig. 69 Cape Town studio group posing with the finished pergola at Ikhaya Le Langa in Langa Township. Courtesy of Nic Coetzer.

would like to portray themselves as individuals and as a community. 

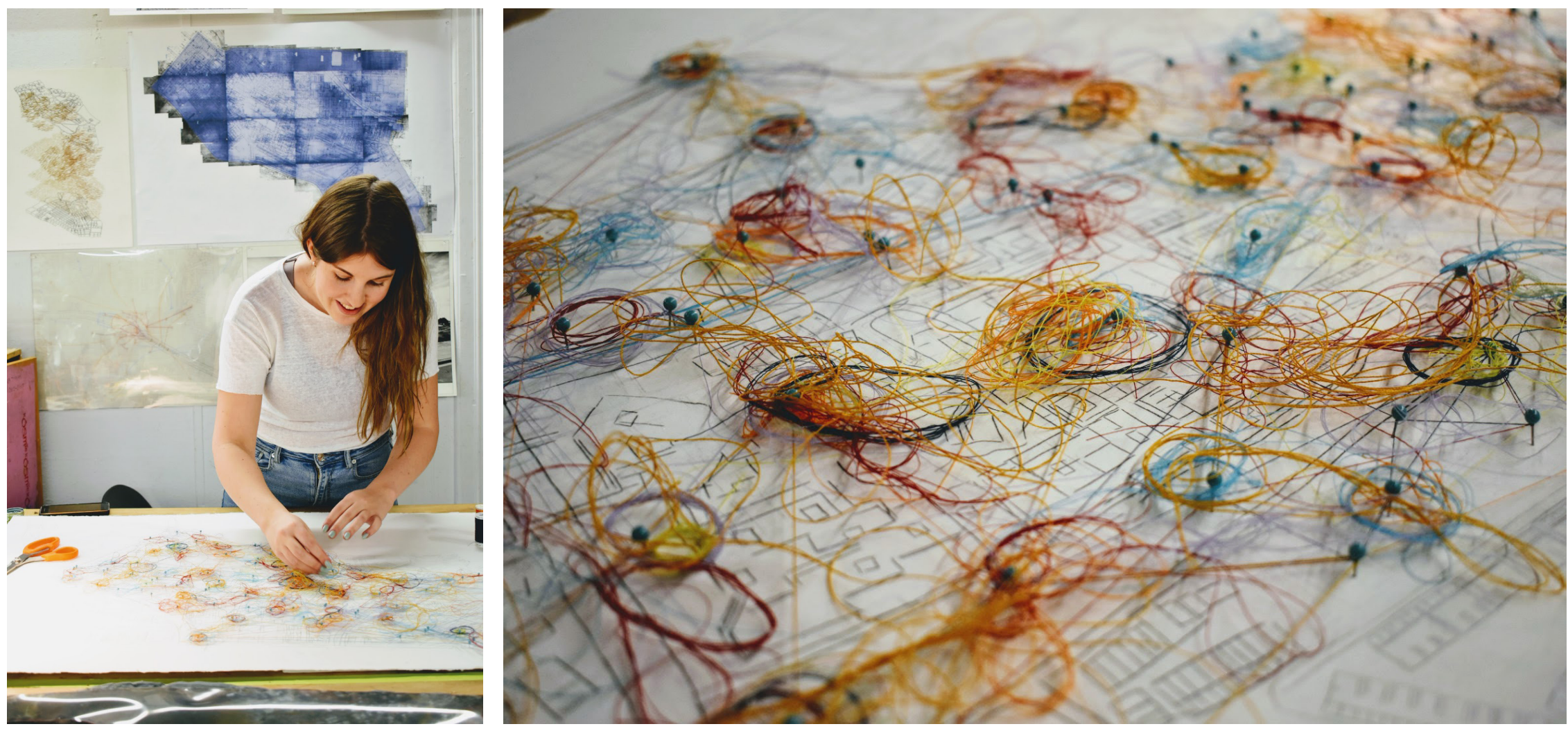


\section{Afterword: 'A Story from Away'}

During my thesis defense on April 16 2020, two possible narratives were brought up with which to consider framing my project. The first involved framing my thesis as a proposal for a speculative architecture with real world potential, while the other argued that my project was more of a 'story from away.' Looking back on the project and analyzing the feedback, I believe framing the project as a 'story from away' can help to further shed light on the intent of this thesis.

But, what does it mean to tell a story from away? To me, telling a story from away began with the acknowledgement of my place as an outsider to the context of this story. As an outsider, I will never have the same experiences, understanding or knowledge of Cape Town or South Africa as someone who has lived there. I don't believe however that this should ever be a disqualifier for anyone who ever genuinely desires to better understand another place and its people. Instead, it is a position with a high level of responsibility; responsibility to be sensitive, to understand, to be critical and to tell a story about a place through the best medium possible. In my case, architecture was the lens I chose to better understand and tell this story about Cape Town. Because this thesis has always been about agency, it was always very important to me that throughout the creation of this story that I acknowledge the people and sources that I was using as the real agents of mobility, voice and view, even when this required acts of interpretation. By doing so, it has never been my intention to speak for them, but rather with them.

The dreamlike and magical quality of the representation of this story works to bring out the underlying theme of this project which is the critique of fixed forms of understanding and knowledge. By using palimpsest and animation, the world of this thesis is portrayed as a space that is in constant continuation. Multiple stories and multiple points of view are woven together, connecting and transcending time, space and place to imagine an architecture and a story that 
is continuously being created, written and imagined. In this sense the story is aspirational, and argues that knowledge of a place and its people are never constant. Instead, the world is a place where multiple forms of knowledge contribute to a better understanding, creation and experience of the urban environment.

As both the outsider and author of this story, I am able to present a different way of looking at the situation of District Six, that is not necessarily beholden to the same context and point of view of a story told by someone from South Africa. Architecture becomes my storytelling tool and is used as an imaginative device to both question and pose a different way of seeing. Though this project was positioned more as an imagined architecture with themes of power and agency, I believe it still has the potential to contribute to and affect, influence and change future perceptions of District Six in the real world. Architecture thus acts as a storytelling tool to help us imagine how the world could be, and not necessarily how it is. 


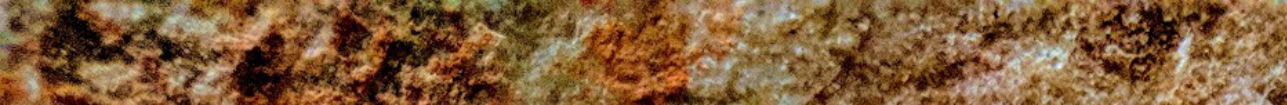

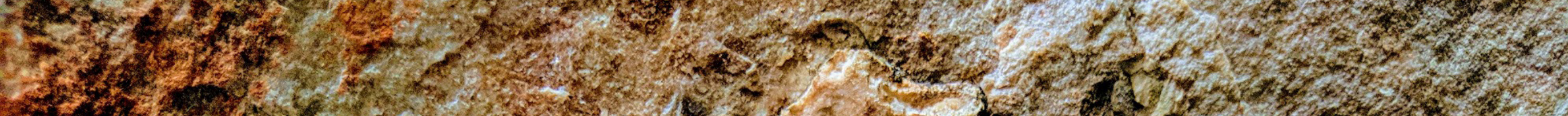

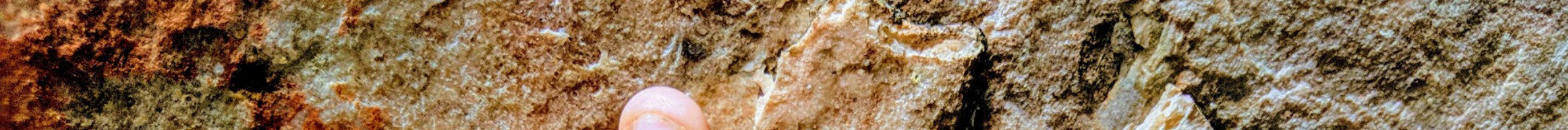
250.7.

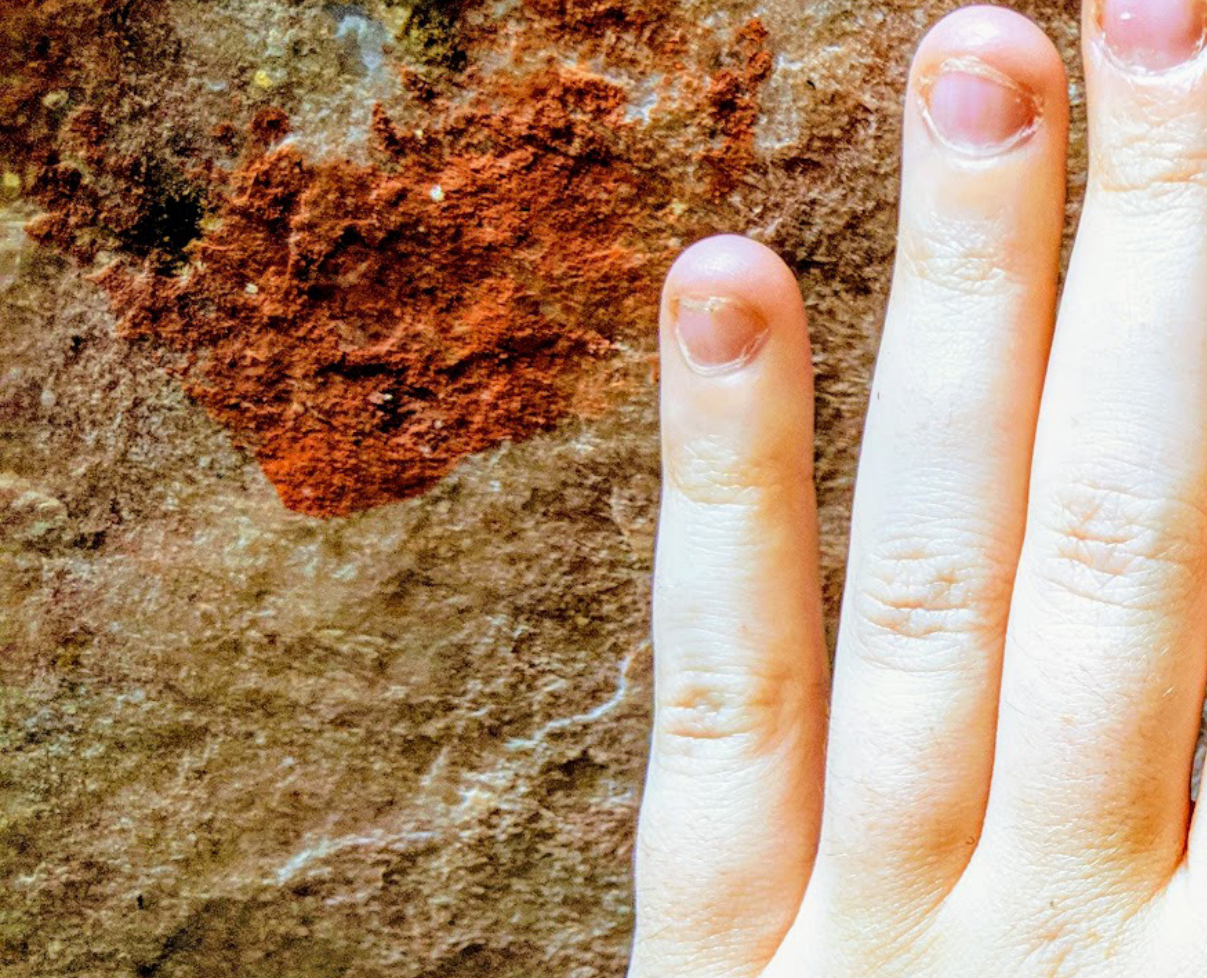

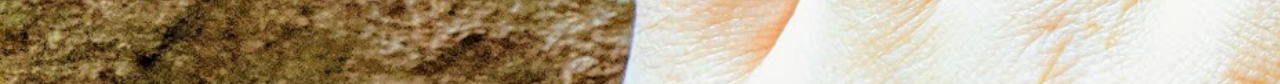
$4 x^{2}+38$ 3) 50.

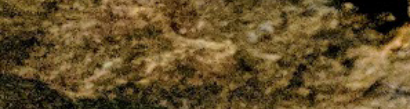

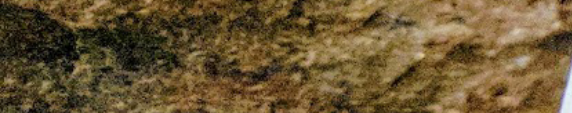

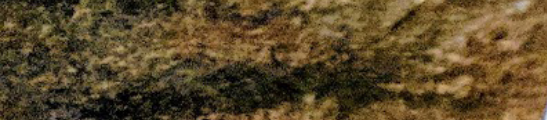

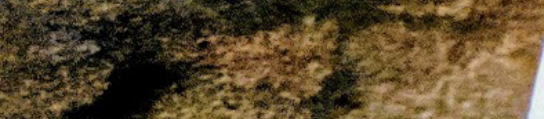
- 40 2. (x) 2.

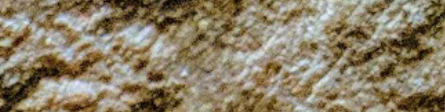

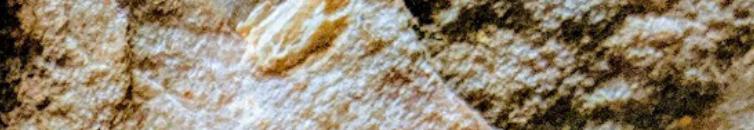

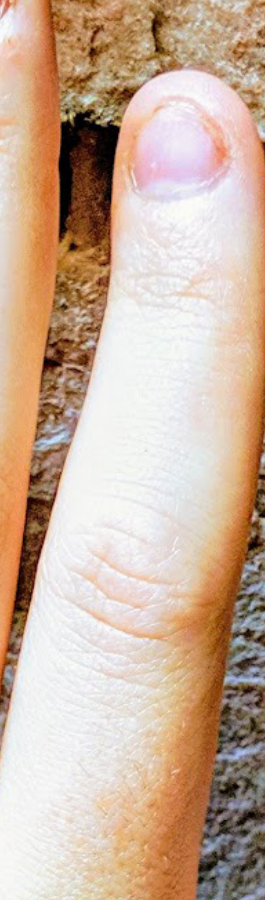

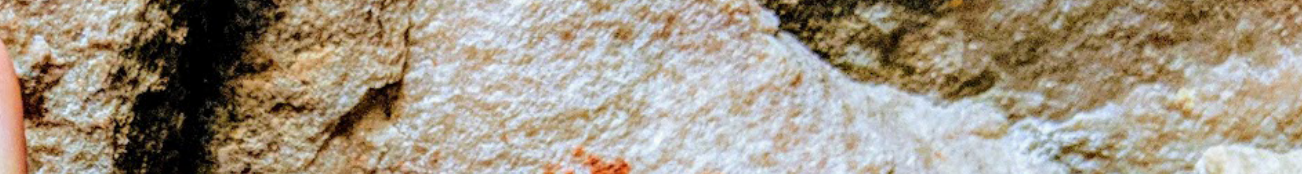
tor.t.

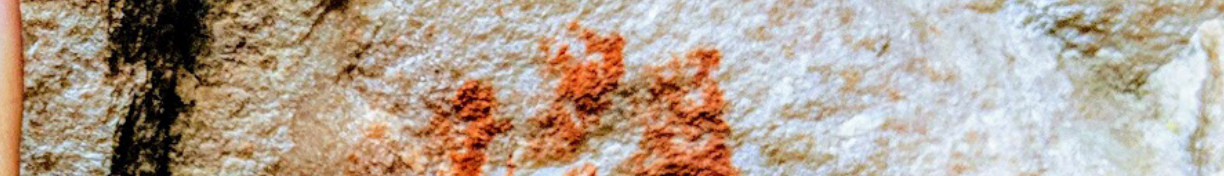

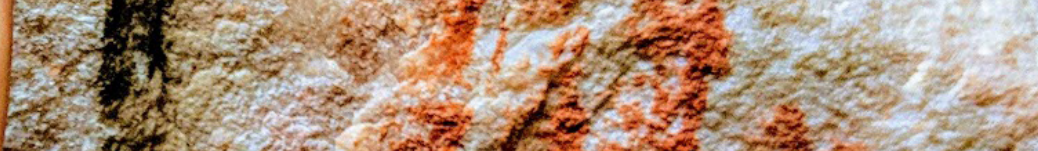
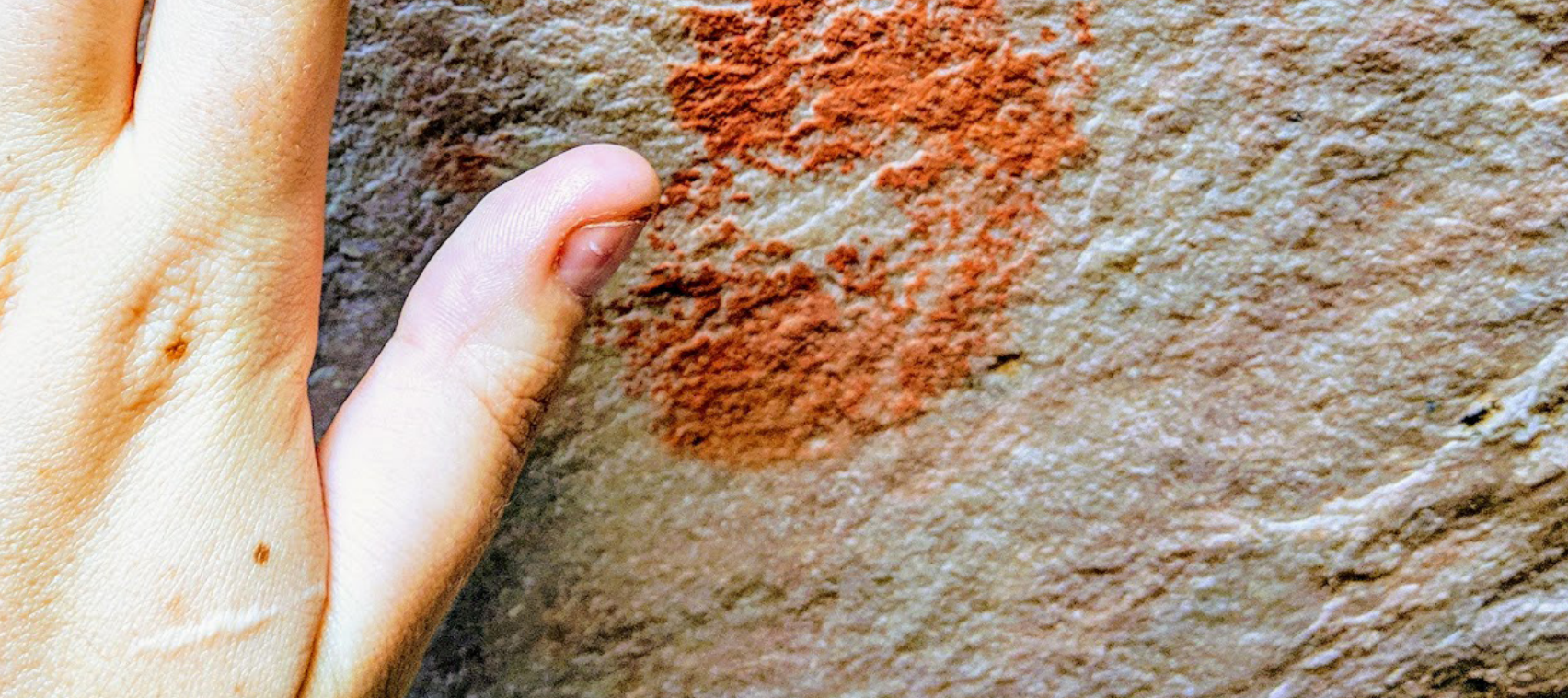

.

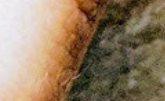

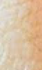

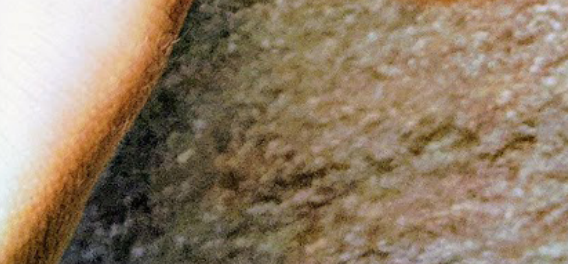

- $x=5$

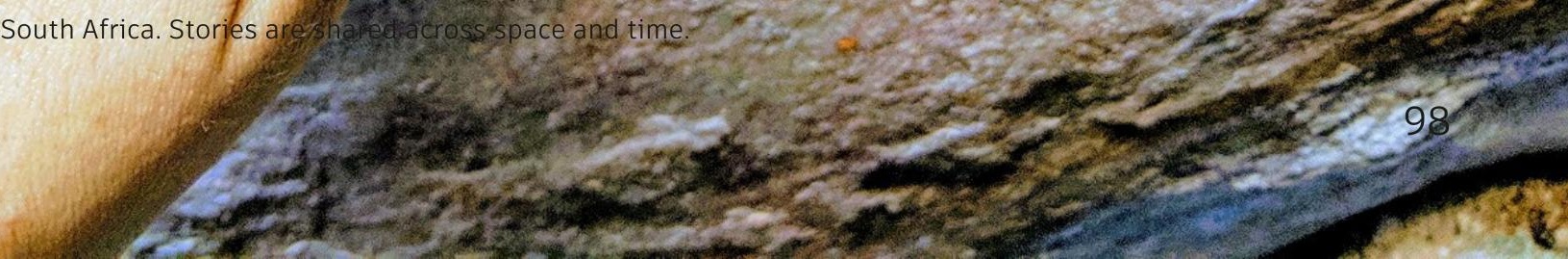




\section{Notes}

1. Aryn Baker, "What South Africa Can Teach Us As Worldwide Inequality Grows." Time Magazine, 2 May 2019, time.com/longform/south-africa-unequal-country/.

2. Jennifer Beningfield, "The Frightened Land: Land, Landscape and Politics in South Africa in the Twentieth Century," London and New York: Routledge, 2006, 230.

3. Penny Pistorious, "Texture and Memory: The Urbanism of District Six," Cape Town: Cape Technikon, 2002, 34-46.

4. Nicholas Coetzer, "Building Apartheid: On Architecture and Order in Imperial Cape Town," Surrey: Ashgate, 2013, 123.

5. Ibid, 118-123.

6. Ibid, 11 .

7. Ibid, $118-123$.

8. Jennifer Beningfield, "The Frightened Land: Land, Landscape and Politics in South Africa in the Twentieth Century," London and New York: Routledge, 2006, 210 and 255.

9. Penny Pistorious, "Texture and Memory: The Urbanism of District Six," Cape Town: Cape Technikon, 2002, 48.
10. Ibid.

11. Jennifer Beningfield, "The Frightened Land: Land, Landscape and Politics in South Africa in the Twentieth Century," London and New York: Routledge, 2006, 210211.

12. Ibid, 218.

13. Penny Pistorious, "Texture and Memory: The Urbanism of District Six," Cape Town: Cape Technikon, 2002, 13.

14. Ibid, 14.

15. Ibid, 16.

16. Nicholas Coetzer, "Building Apartheid: On Architecture and Order in Imperial Cape Town," Surrey: Ashgate, 2013, 1.

17. Ibid, 2.

18. Ibid, 3-4.

19. Penny Pistorious, "Texture and Memory: The Urbanism of District Six," Cape Town: Cape Technikon, 2002, 34-46.

20. Nicholas Coetzer, "Building Apartheid: On Architecture and Order in Imperial Cape Town," Surrey: Ashgate, 2013, 4-5. 


\section{Ibid, 6 .}

22. Ibid.

23. Ibid.

24. Ibid, 6-7.

25. Ibid, 7.

26. Ibid, 8.

27. Ibid.

28. Ibid.

29. Ibid, 9.

30. Ibid.

31. Ibid, 10

32. Ibid.

33. Ibid,83-89.

34. Ibid.

35. Ibid, 90-96.

36. Ibid, 107.
37. Ibid, 113-114.

38. Ibid.

39. Ibid, 192-193.

40. Ibid, 117-118.

41. Ibid.

42. Ibid, 113-114.

43. Ibid.

44. Ibid, 192-193.

45. Ibid, 192-194.

46. Ibid.

47. Ibid.

48. Penny Pistorious, "Texture and Memory: The Urbanism of District Six," Cape Town: Cape Technikon, 2002, 34-46.

49. Ibid.

50. Ibid, 40.

51. Ibid, 32. 
52. Ibid, 32-40.

53. Ibid.

54. Ibid, 48.

55. Ibid 48-52.

56. Lindsay Bremner, "Border/Skin," in Against the Wall: Israel's Barrier to Peace, edited by Michael Sorkin. New York:New Press, 2005. 123.

57. Ibid, 123-124.

58. Ibid.

59. Ibid.

60. Ibid.

61. Ibid, 131.

62. Jennifer Beningfield, "The Frightened Land: Land, Landscape and Politics in South Africa in the Twentieth Century," London and New York: Routledge, 2006, 209210.

63. Ibid, 3.

64. Ibid.
65. Ibid, 270-271.

66. Ibid.

67. Ibid.

68. Penny Pistorious, "Texture and Memory: The Urbanism of District Six," Cape Town: Cape Technikon, 2002, 54

69. Jennifer Beningfield, "The Frightened Land: Land, Landscape and Politics in South Africa in the Twentieth Century," London and New York: Routledge, 2006, 275276.

70. Ibid.

71. Ciraj Rassool and and Sandra Prosalendis, "Recalling Community in Cape Town: Creating and Curating the District Six Museum," Cape Town: District Six Museum, 2001, 68

72. "District Six." Wikipedia, en.wikipedia.org/wiki/ District_Six.

73. Ciraj Rassool and and Sandra Prosalendis, "Recalling Community in Cape Town: Creating and Curating the District Six Museum," Cape Town: District Six Museum, 2001, 68. 
74. Michel de Certeau, "The Practice of Everyday Life," Berkeley: University of California Press, 1984, 97.

75. Ibid.

76. Ibid, 98.

77. Jennifer Beningfield, "The Frightened Land: Land, Landscape and Politics in South Africa in the Twentieth Century," London and New York: Routledge, 2006, 217.

78. Ibid, 209.

79. Ibid.

80. Italo Calvino, "Invisible Cities," Orlando: Harcourt Brace \& Company, 1972, 38-39.

81. Ibid.

82. Ibid.

83. Ibid, 36-37.

84. Ibid.

85. Jennifer Beningfield, "The Frightened Land: Land, Landscape and Politics in South Africa in the Twentieth Century," London and New York: Routledge, 2006, 260.

86. Ibid, 229.
87. Ibid, 225.

88. Ibid.

89. Ibid, 221.

90. Ibid, 220.

91. Ibid, 221.

92. Susan Sontag, "On Photography," New York: Picador, 1933, 5.

93. Ibid.

94. Ibid, 9

95. Ibid, $22-24$

96. Trevor Paglen Experimental Geography: From Cultural Production to the Production of Space, in "Critical Landscapes: Art, Space, Politics," edited by Emily Eliza Scott and Kirsten Swenson. Oakland: University of California Press, 2015. 34-42.

97. Jennifer Beningfield, "The Frightened Land: Land, Landscape and Politics in South Africa in the Twentieth Century," London and New York: Routledge, 2006, 257.

98. Ibid, 270. 
99. Ibid.

100. Ibid, 8 .

101. Ibid, 11

102. Ibid

103. Ibid, 42.

104. TateShots, William Kentridge: 'Art Must Defend the Uncertain.' Directed by Tate Museum. Tate Museum, 2018.

105. "Acupuncture." Lexico, www.lexico.com/definition/ acupuncture.

106. Nicholas Coetzer, "Building Apartheid: On Architecture and Order in Imperial Cape Town," Surrey: Ashgate, 2013, 224. 


\section{Bibliography}

Baderoon, Gabeba. "Three Poems." African Cities Reader (2009): 73-78.

Baker, Aryn. "What South Africa Can Teach Us As Worldwide Inequality Grows." Time Magazine, 2 May 2019, time.com/longform/south-africaunequal-country/.

Beningfield, Jennifer. The Frightened Land: Land, Landscape and Politics in South Africa in the Twentieth Century. London and New York: Routledge, 2006.

Berti, Adele. "Cape Town: will the city ever rebuild its railway?" Railway Technology, 1 Aug. 2019, www.railway-technology.com/features/capetown-transport/.

Beyers, Christiaan. “Land Restitution's ‘Rights Communities': The District Six Case." Journal of South African Studies, vol. 33, no. 2 (2007): 267285.

---. "The Cultural Politics of 'Community' and Citizenship in the District Six Museum, Cape Town." Anthroplogica, vol. 50, no. 2 (2008): 259373.
Bickford-Smith, Vivian. "Creating a City of the Tourist Imagination: The Case of Cape Town, 'The Fairest Cape of Them All'." Urban Studies 46, no. 9 (2009): 1736-1785.

---. "Providing Local Color?: 'Cape Coloreds,' 'Cockneys,' and Cape Town's Identity from the Late Nineteenth Century to the 1970's." Journal of Urban History 38, no. 1 (2012): 133-151.

---. "Introduction: The Case for Studying Cities and Nationalisms." Journal of Urban History 38, no. 5 (2012): 855-861.

---. "Urban History in the New South Africa: Continuity and Innovation Since the End of Apartheid." Journal of Urban History 35, no. 2 (2008): 288315.

---. "South African Urban History, Racial Segregation and the Unique Case of Cape Town?" Journal of Southern African Studies, vol. 21, no. 1 (1995): 6378.

Bremner, Lindsay. "Border/Skin," in Against the Wall: Israel's Barrier to Peace, edited by Michael Sorkin. New York: New Press, 2005. 122-137.

Calvino, Italo. Invisible Cities. Orlando: Harcourt Brace \& Company, 1972. 
Certeau, Michel de. The Practice of Everyday Life. Berkeley: University of California Press, 1984.

Coetzer, Nicholas. Building Apartheid: On Architecture and Order in Imperial Cape Town. Surrey: Ashgate, 2013.

Dangor, Achmat. 'Paradise,' in Bulldozer, Johannesburg: Raven Press, 1983, 3.

Davids, Jennifer. 'Location Fires' in Chapman, Michael and Dangor, Achmate (eds) Voices from Within: Black Poetry from South Africa, Johannesburg: Ad. Donker, 1982, 97.

Demissie, Fassil. "Controlling and 'Civilising Natives' through Architecture and Town Planning in South Africa." Social Identities 10, no. 4 (2004): 83-507.

District Six Museum, https://www.districtsix.co.za/

Ernsten, Christian. "The Ruins of Cape Town's District Six." Archaeologies: Journal of the World Archaeological Congress (2015): 342-371.

Foucault, Michel. "Of Other Spaces." Diacritics 16, vol. 16, no 1 (1986): 22-27.

---. "The Subject and Power." Michel Critical Enquiry, vol. 8, no. 4 (1982): 777-795.
Hayes, Patricia. "Santu Mofokeng, Photographs: 'The Violence is in the Knowing'." History and Theory, vol. 48, no. 4 (2009): 34-51.

Haziza, Natalie. "Under Erasure: William Kentridge, Derrida and Post-Apartheid South Africa." Studies in Gender and Sexuality 19, no. 2 (2018): 133-144.

Jeppie, and Crain Soudien. The Struggle for District Six: Past and Present. Hands Off District Six Committee: Cape Town: Buchu Books, 1990.

Jethro, Duane. "Waar Val Jy Uit?: District Six, Sacred Space, and Identity in Cape Town." Journal for the Study of Religion 22, no. 1 (2009): 17-41.

Kentridge, William. William Kentridge: Anything is Possible. Directed by PBS (Firm) and Infobase. PBS, 2010.

---. Felix in Exile. 1994. 202, MoMA, 2020. www.moma.org/audio/playlist/1/248.

Lexico, "Acupuncture," Lexico Oxford Dictionary, https:// www.lexico.com/en/definition/acupuncture

Lyotard, Jean-François. The Post-Modern Condition: A Report on Knowledge. Vol 10. Minneapolis: University of Minnesota Press, 1984. 
Mabin, Alan. “Comprehensive Segregation: The Origins of the Group Areas Act and Its Planning Apparatuses."Journal of Southern African Studies, vol. 18, no. 2 (1992): 405-429.

Markham, Katie. "Two Dimensional Engagements: Photography, Empathy and Interpretation at the District Six Museum." International Journal of Heritage Studies 25, no. 1 (2019):21-42.

Maylim, Paul. "Explaining the Apartheid City: Twenty Years of South African Urban Historiography." Journal of South African Studies, vol. 21, no. 1 (1995): 19-38.

McEachern, Charmaine. "Working with Memory: The District Six Museum in the New South Africa." Social Analysis: The Journal of Anthropology, vol. 42, no. 2 (1998): 48-72.

Miller, Johnny. "District Six," Unequal Scenes, https:// unequalscenes.com/district-six.

O'Connell, Siona. "The Aftermath of Oppression: In Search of Resolution through Family Photographs of the Forcibly Removed of District Six, Cape Town." Social Dynamics 40, no. 3 (2014): 589-596.
Paglen, Trevor. "Experimental Geography: From Cultural Production to the Production of Space," in Critical Landscapes: Art, Space, Politics, edited by Emily Eliza Scott and Kirsten Swenson. Oakland: University of California Press, 2015. 3442.

Pistorius, Penny. Texture and Memory: The Urbanism of District Six. Cape Town: Cape Technikon, 2002.

Pomerantz, Katherine. "The Story Behind TIME's Cover on Inequality in South Africa." TIME, Time Magazine, 2 May 2019, https://www.time. com/5581483/time-cover-south-africa/.

Rassool, Ciraj. "The Politics of Nonracialism in South Africa.” Public Culture 31, no. 2 (2019): 343-371.

---. "Making the District Six Museum in Cape Town." Museum International 58, no 1-2 (2006) 9-18.

---. "Power, Knowledge and the Politics of Public Pasts." Journal of African Studies 69, no. 1 (2010): 79101.

---, and Sandra Prosalendis. Recalling Community in Cape Town: Creating and Curating the District Six Museum. Cape Town: District Six Museum, 2001. 
Rive, Richard. Buckingham Palace District Six. South Africa: David Philip Publisher Ltd, 1986.

Said, Edward. "Invention, Memory and Place." Critical Inquiry, vol. 26, no. 2 (2000): 175-192.

Serote, Mongane Wally. (1974), 'Death Survey,' in Tsetlo, Johannesburg: Ad, Donker, 48.

Sontag, Susan. On Photography. New York: Picador, 1933.

TateShots. William Kentridge: 'Art Must Defend the Uncertain.' Directed by Tate Museum. Tate Museum, 2018.

Wissema, Jansje. UCT Libraries Digital Collections, University of Cape Town. https://www.

digitalcollections.lib.uct.ac.za/jansje-wissema. 